Universidad de Lima

Facultad de Comunicación

Carrera de Comunicación

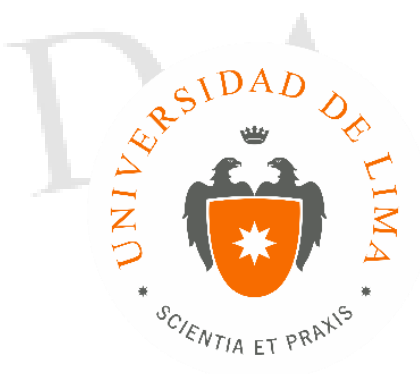

\title{
ESTRATEGIA DIGITAL PARA LA EMPRESA PROVEJEC SAC
}

Trabajo de Suficiencia Profesional para optar el Título Profesional de Licenciado en Comunicación

\section{Carlos Enrique Salazar Claudet}

Código 20071846

Asesor

Manuel Santillán

Lima-Perú

Mayo del 2017 

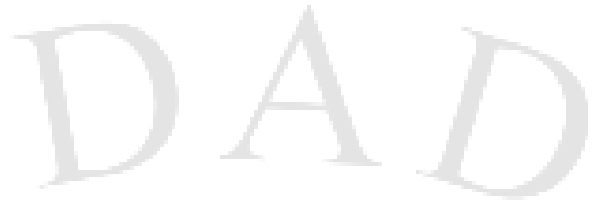

ESTRATEGIA DIGITAL PARA LA EMPRESA PROVEJEC SAC
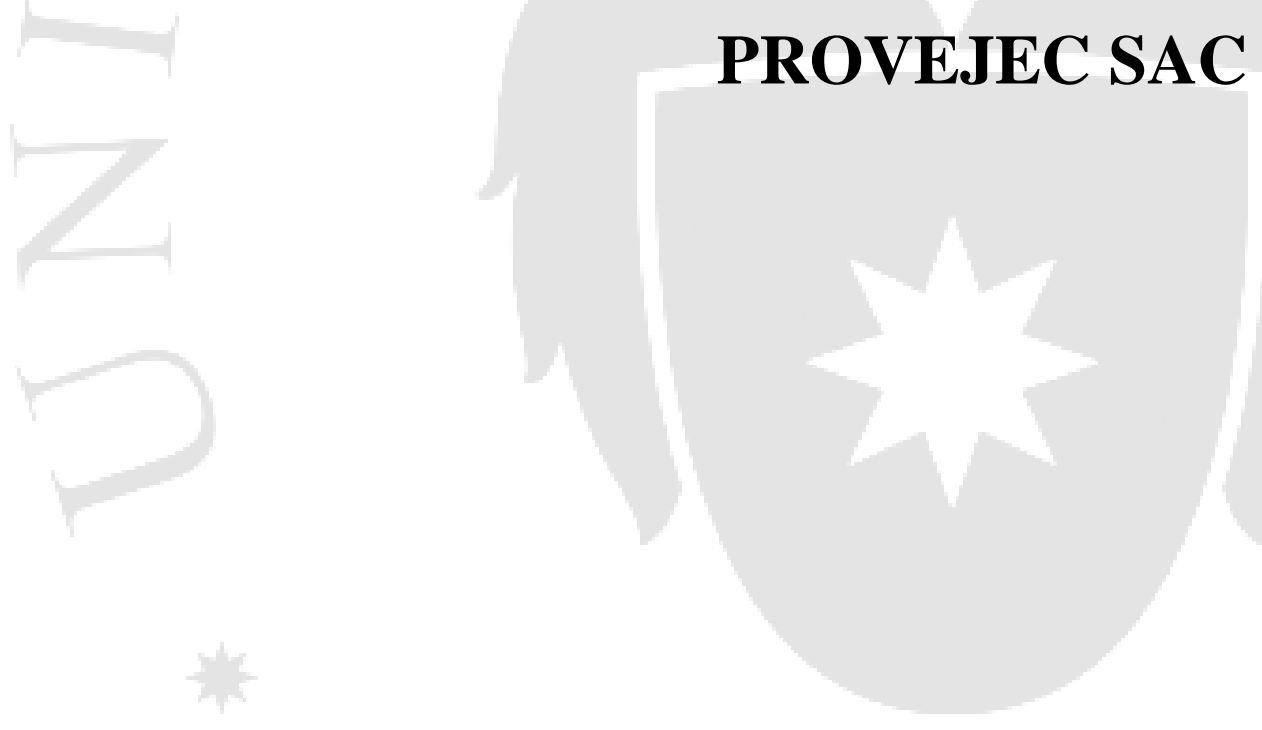


\section{TABLA DE CONTENIDO}

CAPÍTULO I: DIAGNÓSTICO DEL ECOSISTEMA DIGITAL .................. 12

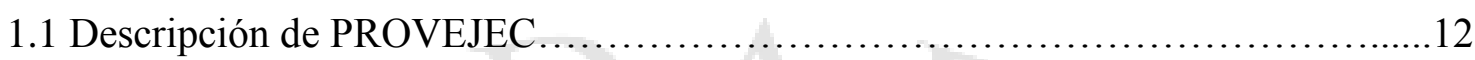

1.2 Diagnóstico del sitio web..................................................13

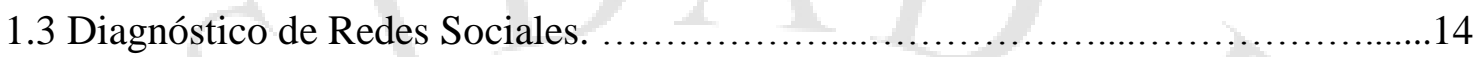

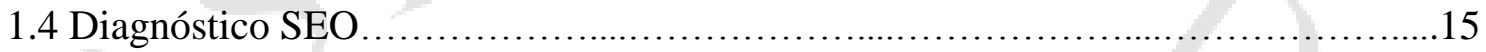

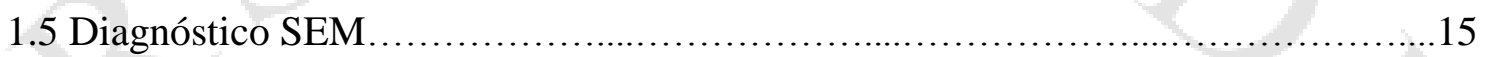

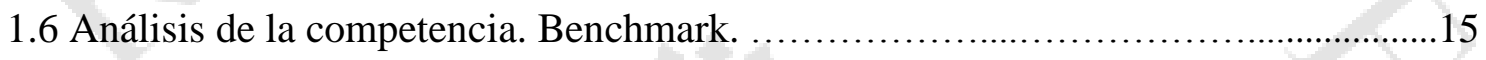

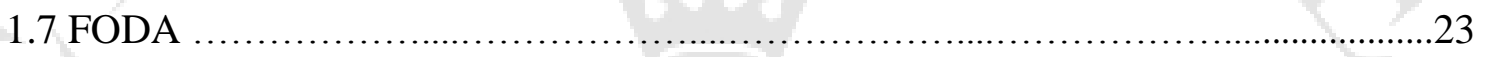

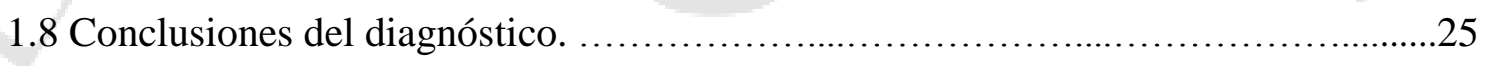

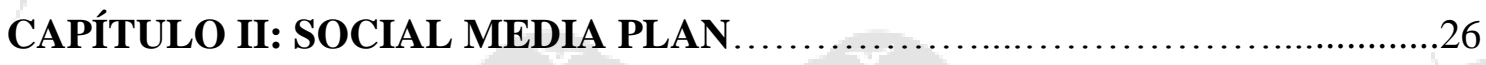

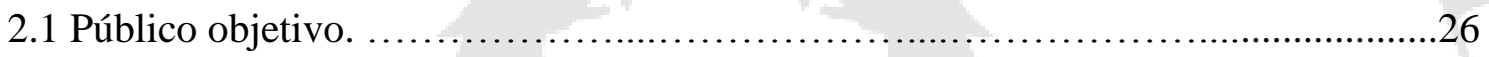

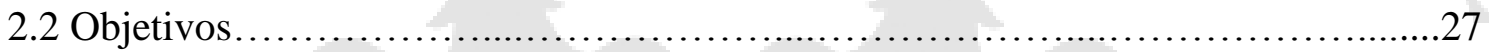

2.3 Matriz del Social Media Plan.......................................................27

CAPÍTULO III: NUEVO SITIO WEB DE PROVEJEC ...............................30

3.1 Desarrollo del nuevo sitio web. ........................................... 30

3.2 Usabilidad y experiencia del usuario........................................... 40

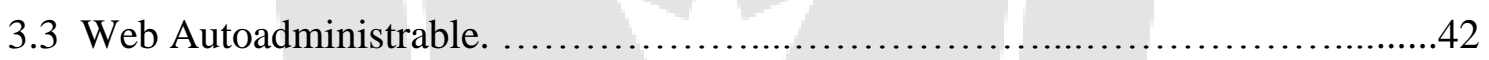

CAPÍTULO IV: ESTRATEGIA EN REDES SOCIALES ...........................47

4.1 Estrategia en Facebook............................................................ 47

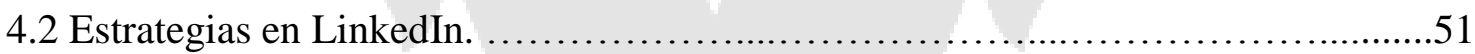

CAPÍTULO V: ESTRATEGIA SEO Y SEM....................................54

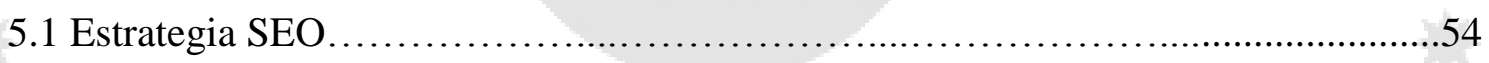

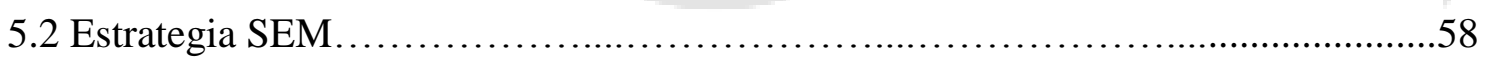

CAPÍTULO VI: VALIDACIÓN DE LAS ACCIONES REALIZADAS EN BASE

A LOS OBJETIVOS PLANTEADOS...........................................61

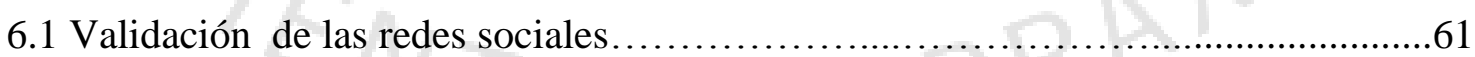

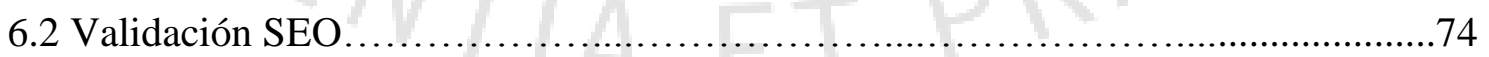

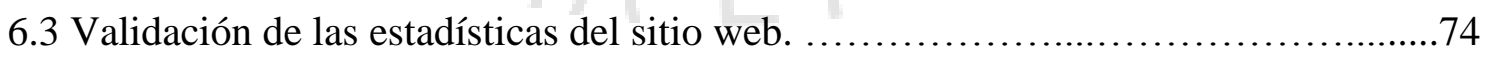

6.4 Validación de solicitudes de cotización por el canal digital. ........................77

CAPÍTULO VII: FUNDAMENTACIÓN CONCEPTUAL ............................79

CAPÍTULO VIII: LECCIONES APRENDIDAS .......................................... 
REFERENCIAS

.110

ANEXOS.

.112

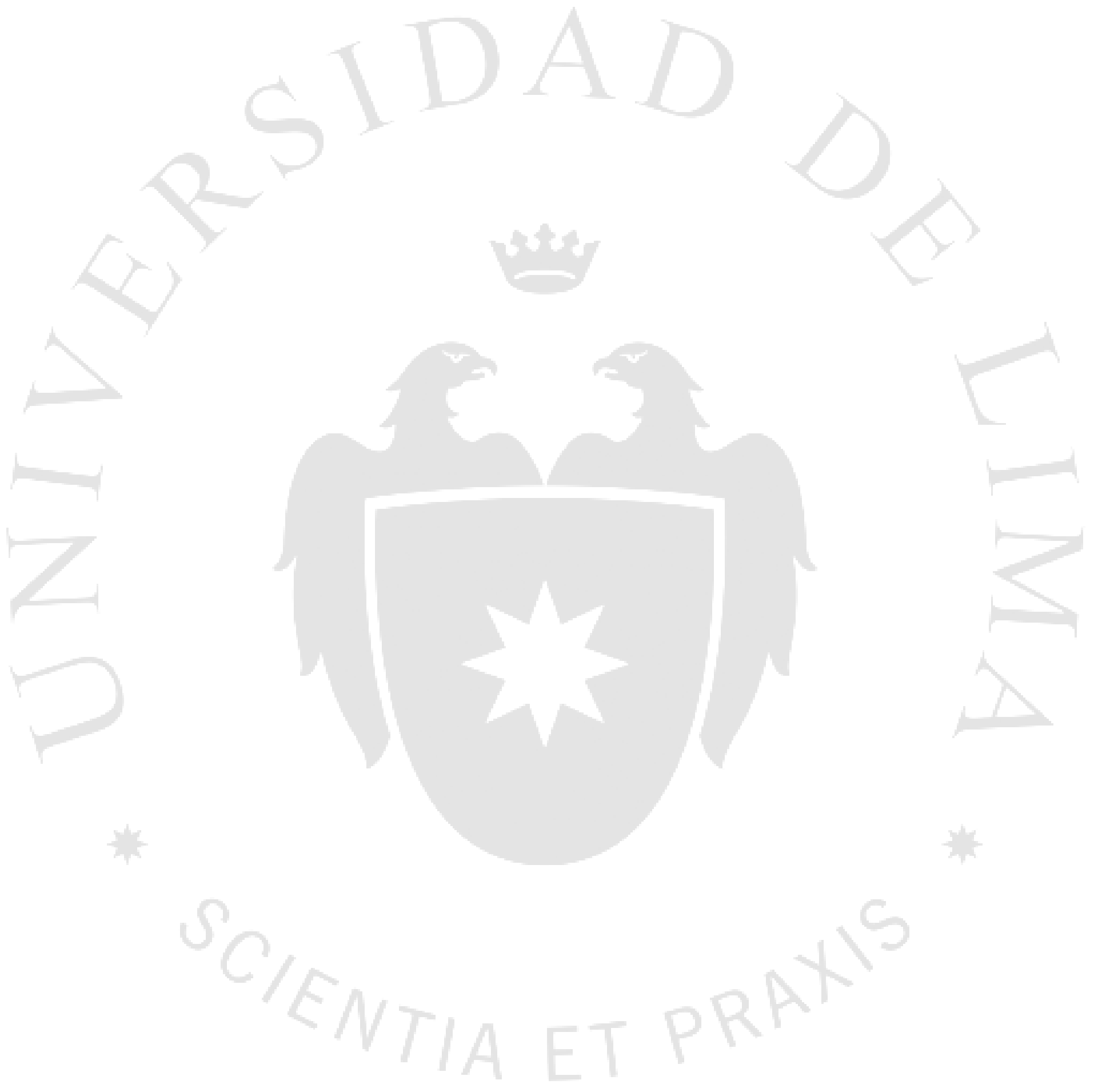

5 


\section{ÍNDICE DE TABLAS}

Tabla 1.1. Análisis del sitio web de los competidores. ......................................16

Tabla 1.2. Análisis del Facebook de los competidores. .......................................18

Tabla 1.3. Análisis del LinkedIn de los competidores. .......................................21

Tabla 1.4 FODA general de Provejec. ...........................................................24

Tabla 1.5. FODA comunicacional de Provejec. .....................................................25

Tabla 2.1. Matriz Social Media........................................................27

Tabla 4.1. Segmentación de publicaciones de Facebook. .....................................51

Tabla 4.2. Segmentación de publicaciones LinkedIn. ..............................53

Tabla 5.1. Palabras clave para la campaña de anuncios pagados. ......................59

Tabla 6.1. Estadísticas de la publicación de promoción de productos. .................62

Tabla 6.2 Estadísticas de la publicación de consejo de ahorro de energía. .............64

Tabla 6.3 Estadisticas de la publicación de casos de éxito. ..............................65

Tabla 6.4 Estadisticas de la publicación de contenido viral. ..............................67

Tabla 6.5 Estadisticas de la publicación de servicios. .......................................68

Tabla 6.6 Métricas generales de Facebook. .....................................................68

Tabla 6.7 Métricas de la publicación casos de éxito. .........................................71

Tabla 6.8 Métricas de la publicación de servicio intergral. ................................72

Tabla 6.9 Métricas de la publicación sobre branding. ..........................................73

Tabla 6.10 Métricas generales de la campaña de LinkedIn. ...............................74

Tabla 6.11 Posiciones orgánicas de la principales palabras clave. .......................74

Tabla 6.12 Métricas generales del sitio web. .................................... 75

Tabla 6.13 Número de solicitudes de cotización. .............................................78

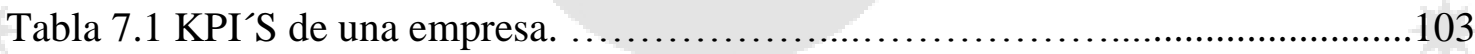




\section{ÍNDICE DE FIGURAS}

Figura 1.1 Antiguo sitio web de Provejec............................................ 14

Figura 1.2 Página de portada del sitio web de Ferreyros...................................17

Figura 1.3 Página de portada del sitio web de Modasa........................................17

Figura 1.4 Página de portada del sitio web de Cummis.....................................18

Figura 1.5 Publicación de Facebook de Ferreyros ............................................19

Figura 1.6 Publicación de Facebook de Modasa..................................................19

Figura 1.7 Publicación Facebook de Cummis...................................................20

Figura 1.8 Métricas del Facebook de los competidores. ....................................21

Figura 1.9 Publicación de LinkedIn de Modasa. ................................................22

Figura 1.10 Publicación de LinkedIn de Cummis............................................22

Figura 1.11 Publicación LinkedIn Ferreyros.................................................23

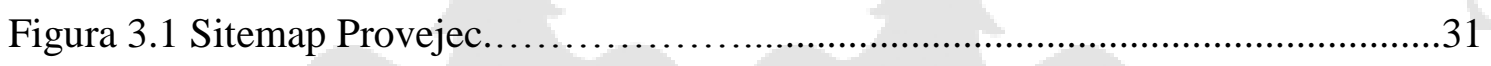

Figura 3.2 Página principal y primer banner del sitio web de Provejec..................32

Figura 3.3 Segundo banner de la página home. ...................................33

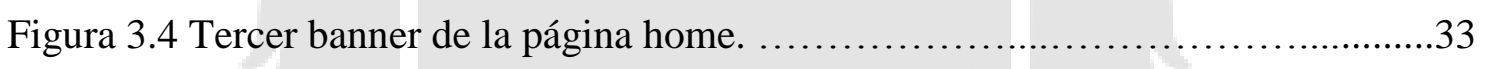

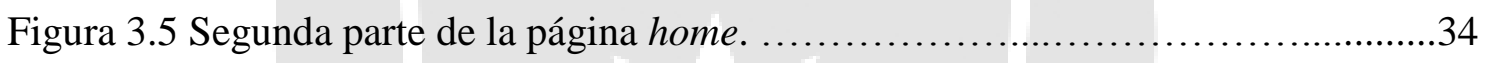

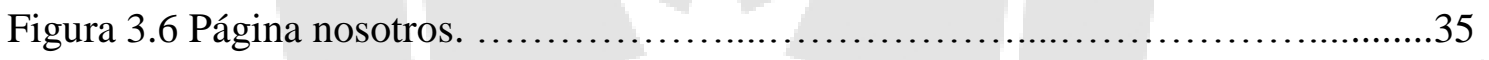

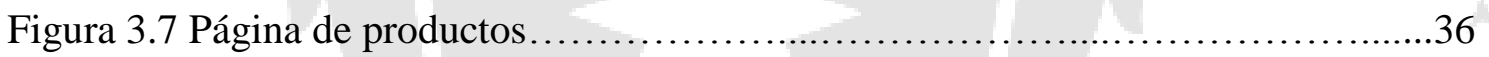

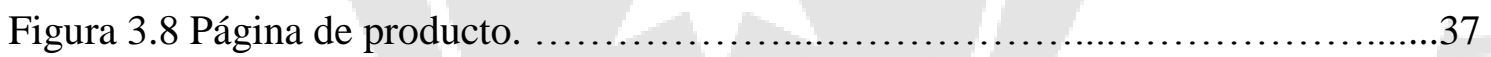

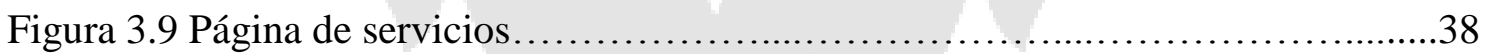

Figura 3.10 Página de servicios............................................... 38

Figura 3.11 Página Provejec TV ............................................. 39

Figura 3.12 Página de contacto...............................................40

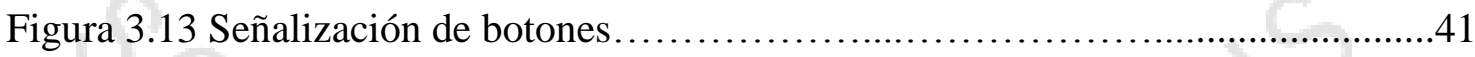

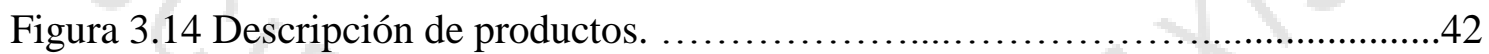

Figura 3.15 Interfaz del administrador de contenidos..............................44

Figura 3.16 Interfaz del sitio web en el explorador safari.................................45

Figura 3.17 Interfaz del sitio web en una tablet. ....................................45

Figura 3.18 Interfaz del sitio web en el explorador Mozila..............................46

Figura 3.19 Interfaz del sitio web en un celular. ................................48

Figura 4.1 Planificación del contenido y pauta de Facebook.............................48 
Figura 4.2 Publicación de contenido viral en Facebook.

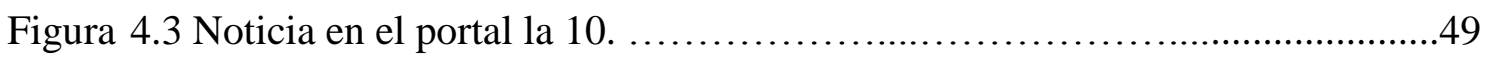

Figura 4.4 Noticia en el portal de RPP. ................................................50

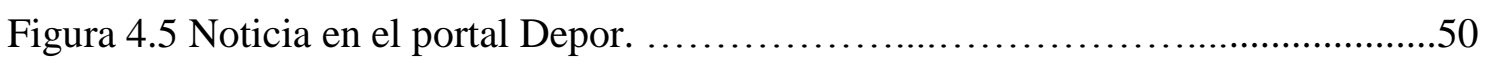

Figura 4.6 Planificación del contenido y pauta de LinkedIn................................52

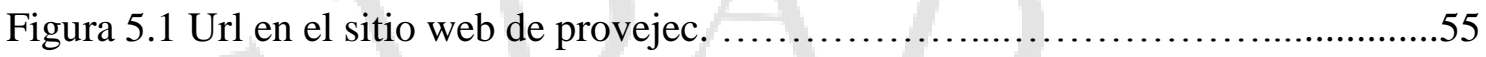

Figura 5.2 Velocidad de descarga del sitio web de Provejec. ............................56

Figura 5.3 Video sobre campeonato de fútbol día del trabajo. ............................57

Figura 5.4 Video sobre el funcionamiento de un grupo electrógeno....................57

Figura 5.5 Resultado de búsqueda de la palabra clave "deep sea electronics peru”......58

Figura 5.6 Anuncio de Google Adword de Provejec..................................60

Figura 6.1 Publicación promoción de productos......................................61

Figura 6.2 Comentarios de la publicación de Facebook.....................................62

Figura 6.3 Adquisición de la publicación.............................................63

Figura 6.4 Publicación de consejo ahorro de energía................................64

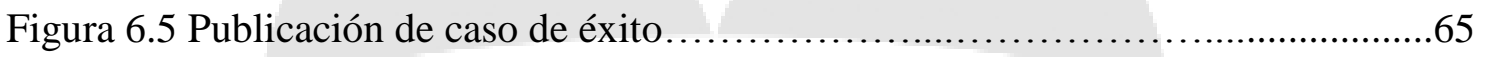

Figura 6.7 Publicación de contenido viral...........................................66

Figura 6.8 Publicación de servicios. ...................................................67

Figura 6.9 Progreso de me gustas del fanpage de Provejec.................................69

Figura 6.10 Publicación LinkedIn sobre caso de éxito....................................70

Figura 6.11 Publicación de LinkedIn sobre el servicio integral. .......................71

Figura 6.12 Publicación LinkedIn de noticias relacionadas al rubro. ..................72

Figura 6.13 Publicación LinkedIn branding de la marca. ..................................73

Figura 6.14 Gráfico general de las estadísticas web................................73

Figura 6.15 Canales de entrada al sitio web. ....................................... 76

Figura 6.16 Número de visitas de cada página. ..................................77

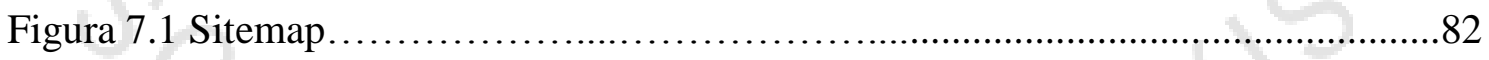

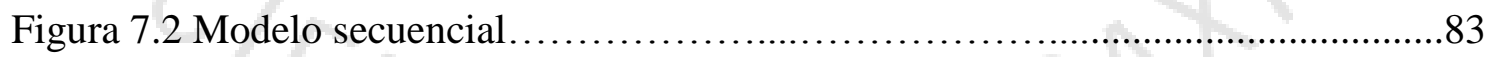

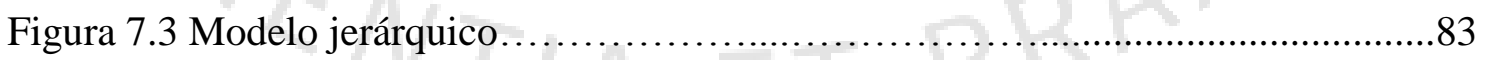

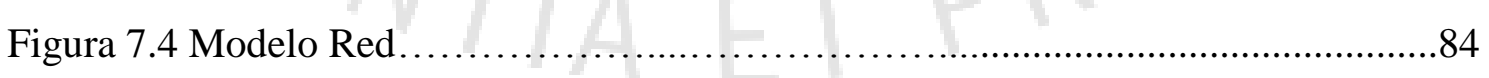

Figura 7.5 Publicidad SEM y resultados SEO ........................................95

Figura 9.1 Palabra: Grupos electrógeno Perú.......................................113

Figura 9.2 Palabra: Grupos electrógeno biogás.................................. 114

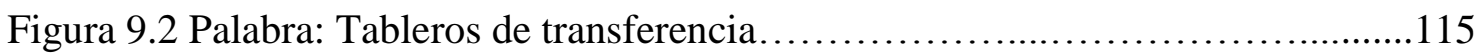


Figura 9.3 Palabra: Carretas. ....................................................... 116

Figura 9.4 Palabra: Deep sea electronic peru....................................117

Figura 9.5 Palabra: Encapsulado Insonorizado.....................................118

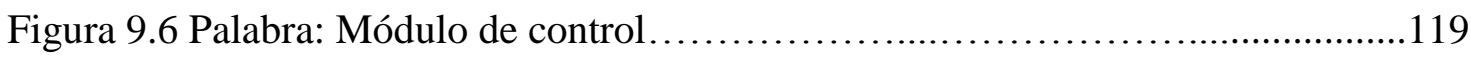

Figura 9.7 Palabra: Tanques de combustible.................................. 120 


\section{ÍNDICE DE ANEXOS}

ANEXO 1: Resultado orgánico de la palabra clave "grupo electrógeno Perú"........113

ANEXO 2: Resultado orgánico de la palabra clave "grupo electrógeno biogás”.......114

ANEXO 3: Resultado orgánico de la palabra clave "tableros de transferencia"........115

ANEXO 4: Resultado orgánico de la palabra clave "Carretas".....................116

ANEXO 4: Resultado orgánico de la palabra clave "Deep sea electronic peru”........117

ANEXO 5: Resultado orgánico de la palabra clave "encapsulado insonorizado"......118

ANEXO 6: Resultado orgánico de la palabra clave "módulo de control".............119

ANEXO 7: Resultado orgánico de la palabra clave "Tanques de combustible"........120 


\section{INTRODUCCIÓN}

Las empresas que perduran son las que aprenden a adaptarse al entorno. Estas han entendido que actualmente el mundo digital es el que está imperando con respecto a las relaciones con los clientes.

En el 2015 Provejec estaba presente en internet sin embargo; no de la manera adecuada. Su sitio web era muy antiguo, sin una estructura de la información adecuada para el rubro y no contaba con buen diseño gráfico. La participación en redes sociales era prácticamente inexistente y no contaba con un plan de social media. En líneas generales el ecosistema digital de Provejec era muy básico. El objetivo principal de este proyecto era mejorar el ecosistema digital. El primer paso fue la gestión de la elaboración de un nuevo sitio web que esté a la vanguardia en diseño gráfico y tecnología. Luego se procedió a plantear y plasmar la estrategia en redes sociales y posteriormente ejecutar las estrategias SEO y SEM. Por último gracias a las métricas y en base a los KPI’S se midió el resultado de la estrategia general del proyecto. Lo que se logró fue mejorar considerablemente el ecosistema digital de Provejec y que éste sea un canal para conseguir solicitudes de cotización. 


\section{CAPÍTULO I: DIAGNÓSTICO DEL ECOSISTEMA DIGITAL}

\subsection{Descripción de PROVEJEC.}

Provejec es una empresa peruana fundada en 1998 que se dedica a la comercialización e instalación de grupos electrógenos, tableros de transferencia, UPS y productos relacionados al rubro de generación de energía eléctrica. También ofrece los servicios de mantenimiento y reparación de grupos electrógenos, alquiler de grupos electrógenos e insonorización de ambientes.

Provejec en sus primeros años sólo fabricaba y suministraba carretas para grupos electrógenos, encapsulados insonorizados y brindaba el servicio de instalación y mantenimiento. En el año 2009 debido al crecimiento de la empresa, empieza a comercializar grupos electrógenos y actualmente es su producto principal.

La empresa realizó una alianza estratégica con la marca inglesa de módulos de control de grupos electrógenos y tableros de transferencia DEEP SEA ELECTRONICS y cuenta con la representación oficial en el Perú por más de 19 años.

Provejec se diferencia en el mercado por tener un servicio integral en el post-venta en todo el Perú. Suministra los equipos, instala los equipos, capacita al cliente y realiza los mantenimientos preventivos correspondientes.

Otros productos que ofrece la empresa son:

- Encapsulados insonorizados.

- Carretas o remolques.

- Banco condensadores

- Purificador de petróleo y aceite.

- Tanques de combustible para grupos electrógenos.

- Regulador de voltaje. 
La empresa cuenta con dos locales. Oficinas administrativas localizadas en Ate y una planta de producción localizada en Huachipa.

\subsection{Diagnóstico del sitio web Enero 2015.}

Era importante tener un diagnóstico del sitio web antiguo para no cometer los mismos errores en la elaboración del nuevo sitio web. Estas son las características que presentaba el sitio web a principios del 2015:

- El sitio web de Provejec mostraba un pobre diseño gráfico. Escasa cantidad de imágenes y las pocas con las que contaba eran de mala calidad y resolución.

- Su arquitectura web se basaba en una página web que incluía toda la información de la empresa. Solo una sección de los productos principales

- No había una jerarquización de la información. No contaba con la barra de menú principal.

- No había una organización del contenido definida. La parte de la descripción de la empresa se encontraba al final del sitio web. En la sección de productos también se definían los servicios.

- No tenía un sistema de administración de contenidos.

- No contaba con sistema de web adaptativo (Responsive).

- Diseño antiguo de los monitores de aspect ratio de 4:3.

- No contaba con una sección de clientes o casos de éxito.

- Sin vínculos de las redes sociales.

- Cada sección de productos tenía una sobrecarga de información y el contenido utilizaba un lenguaje técnico. 
Figura 1.1

Antiguo sitio web de Provejec

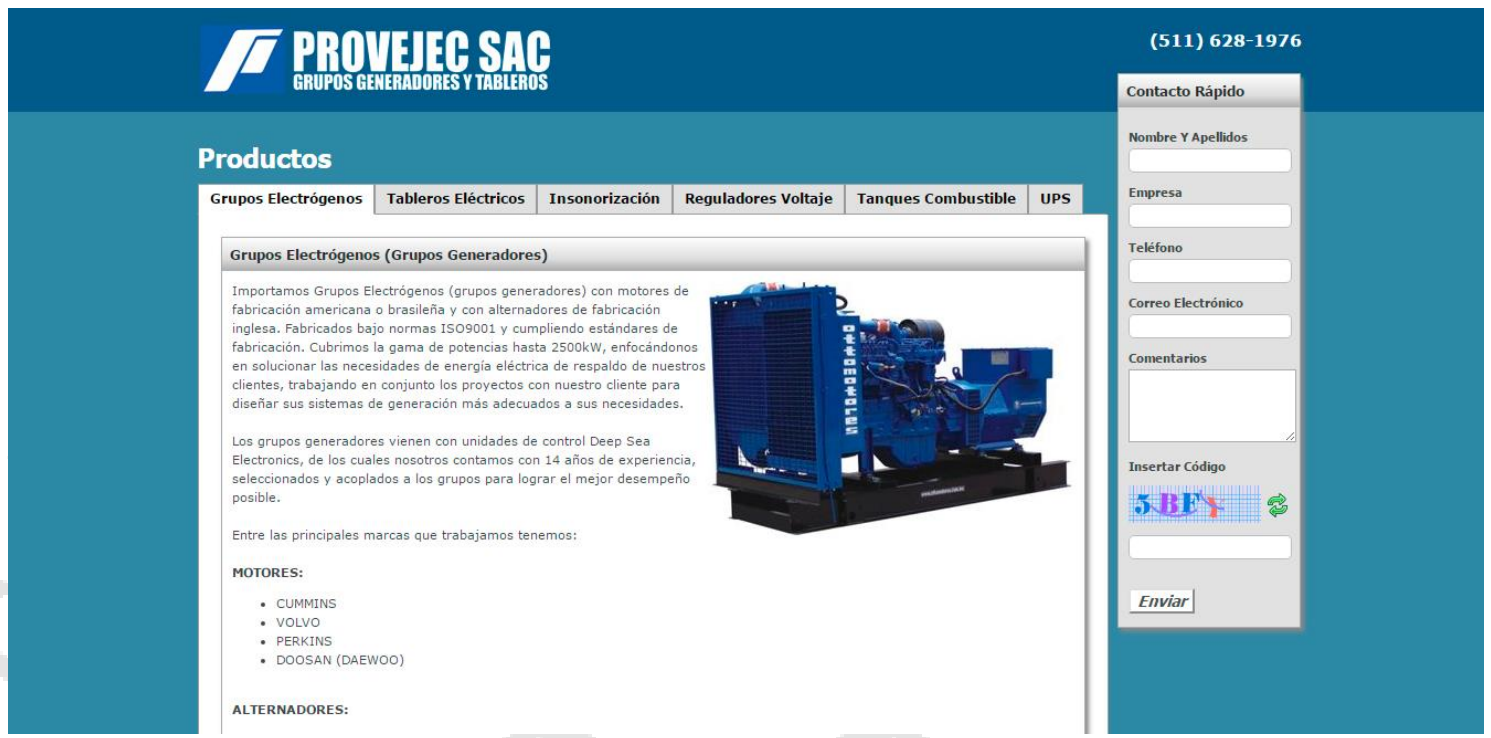

Fuente: Captura de pantalla Enero 2015.

\subsection{Diagnóstico de Redes Sociales Enero 2015.}

Antes de plantear la estrategia en redes sociales y elaborar los ejes temáticos era necesario tener un diagnóstico de las redes sociales de la empresa.

\subsubsection{Facebook}

- Sin plan de contenido definido.

- Publicaciones sin diseño gráfico, ni el branding de la marca.

- 68 fans.

- Poca frecuencia de publicación.

- Nula interacción.

- Publicaciones sin pauta.

- Imágenes de la publicación de baja calidad.

\subsubsection{LinkedIn}

- No contaba con LinkedIn 


\subsection{Diagnóstico SEO Enero 2015.}

Ya que el SEO es un concepto importante para el posicionamiento de los sitios web de las empresas en los motores de búsqueda, se analizó si el sitio web de Provejec tenía buenas prácticas SEO. Este es el diagnóstico que se encontró:

- El sitio web de Provejec eventualmente aparecía en las páginas 8 y 9 de los resultados de búsqueda orgánico.

- No contaba con los metatag básicas para SEO.

- No contaba con estrategia de contenidos.

- Inexistente estrategia de posicionamiento orgánico.

\subsection{Diagnóstico SEM}

- No contaba con anuncios en publicidad en GoogleAdwords.

\subsection{Análisis de la competencia. Benchmark.}

Se analizó el ecosistema digital de los principales competidores de Provejec para tener un panorama digital general. 
1.6.1 Análisis del sitio web de los principales competidores Enero 2015.

Tabla 1.1

Análisis del sitio web de los competidores.

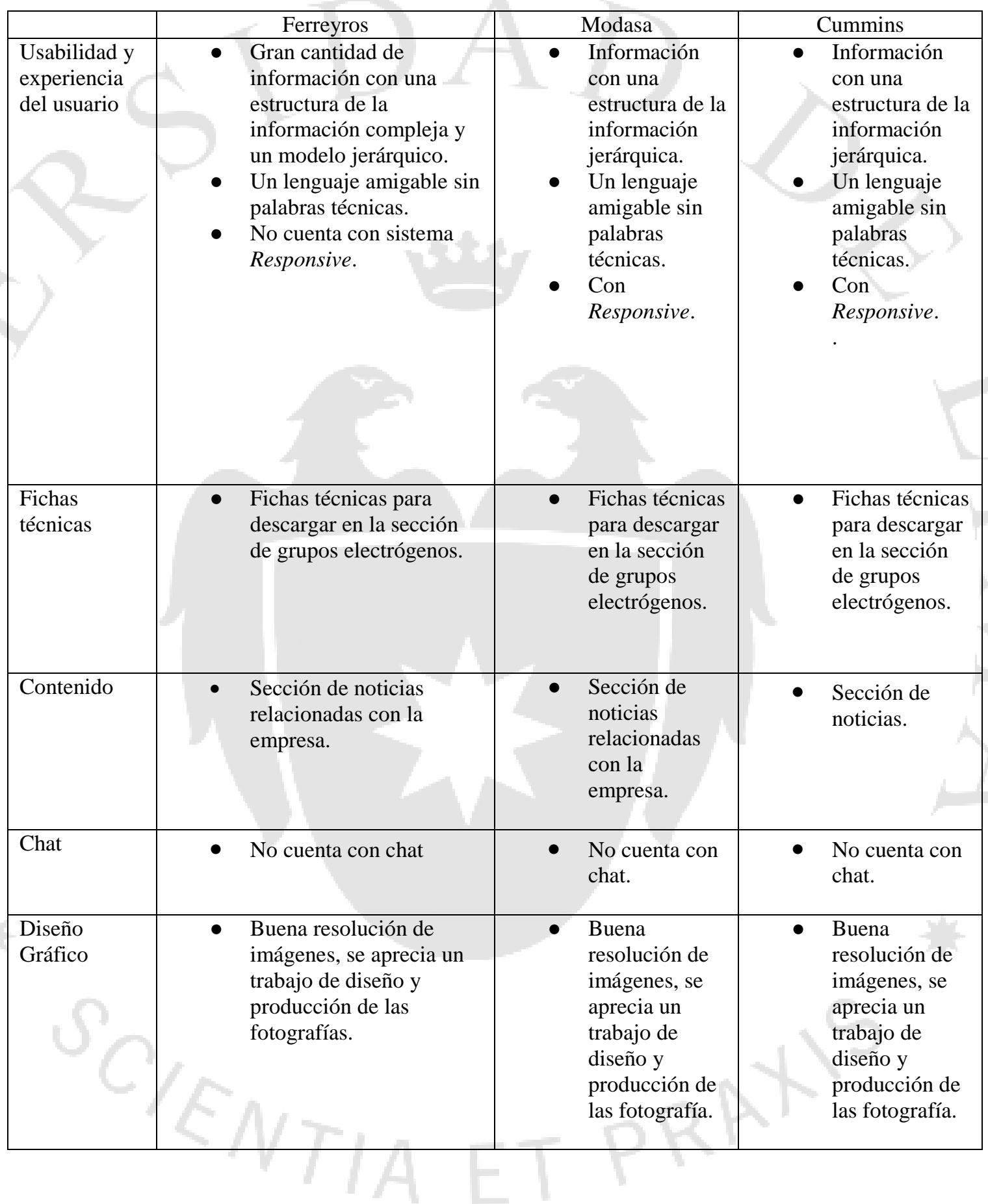


Estas son las imágenes de la página de portada de cada competidor en Enero del 2015.

Figura 1.2

Página de portada del sitio web de Ferreyros

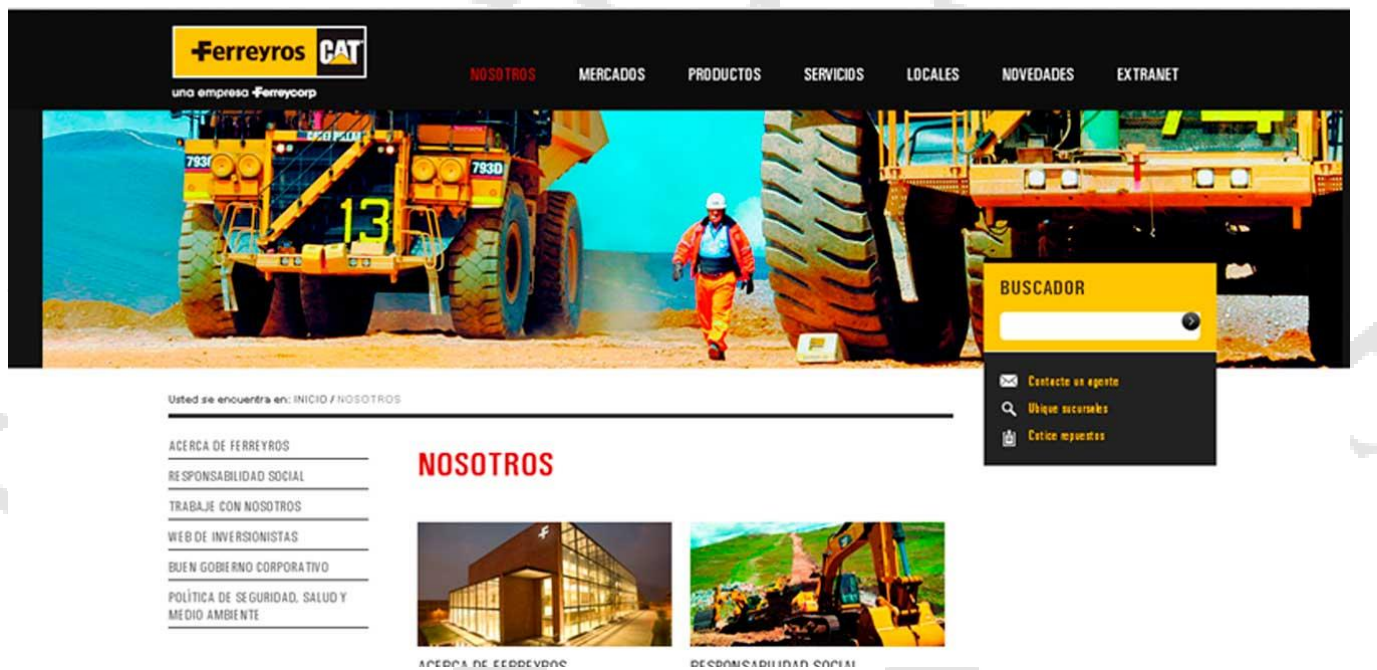

Fuente: Captura de pantalla.

Figura 1.3

Página de portada del sitio web de Modasa

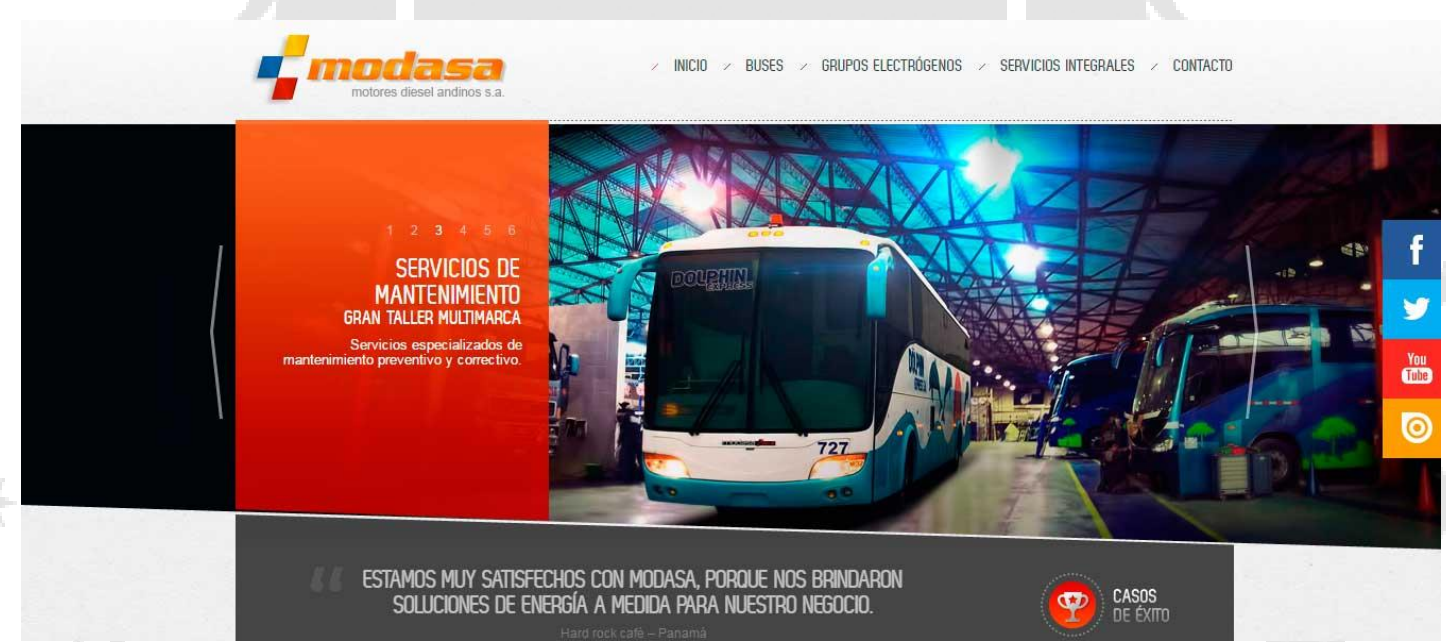

Fuente: Captura de pantalla. 
Figura 1.4

Página de portada del sitio web de Cummis

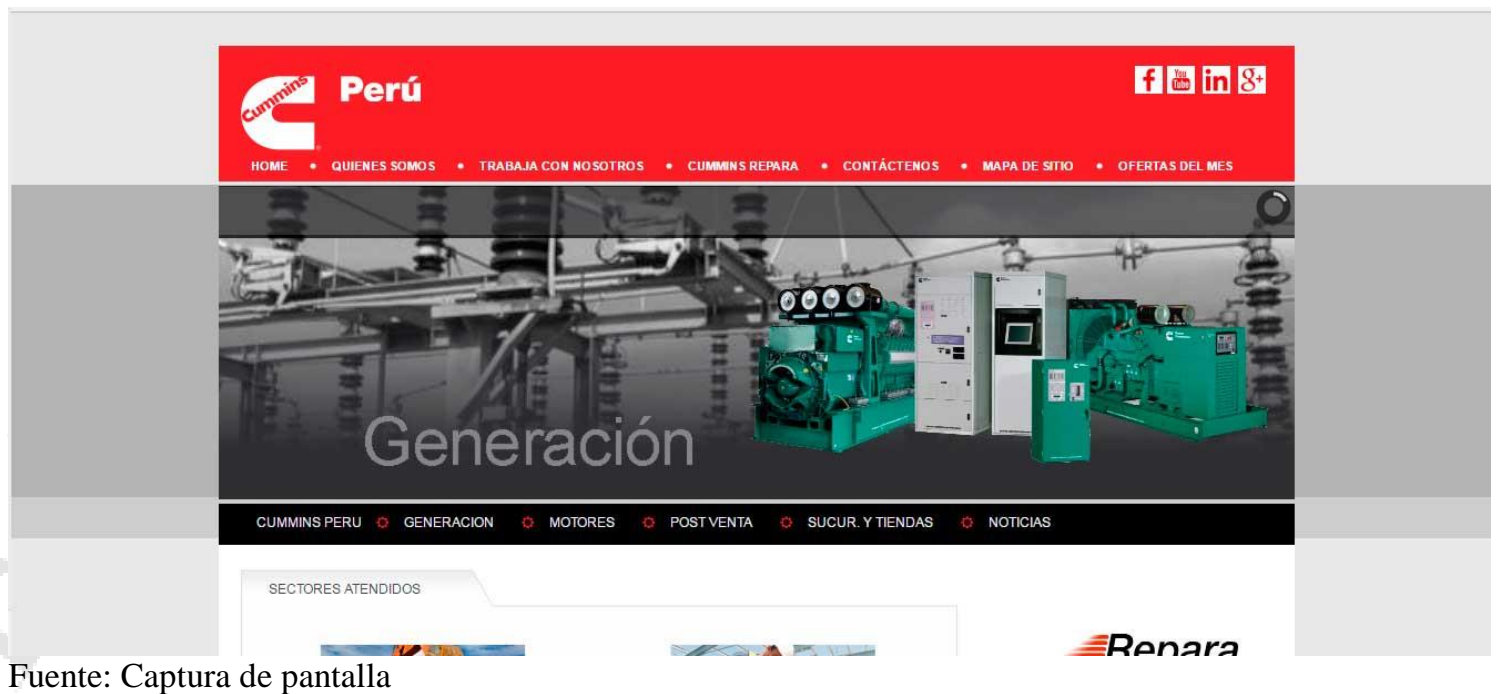

Fuente: Captura de pantalla

En líneas generales los sitios web de los tres competidores directos de Provejec tienen buenas prácticas en internet y son amigables para los clientes. Por otro lado, ninguno de los tres sitios web contiene chat, esto sería una diferencia que tendría el sitio web de Provejec.

\subsubsection{Análisis del Facebook de los competidores Enero 2015.}

Tabla 1.2

Análisis del Facebook de los competidores

\begin{tabular}{|l|l|l|l|}
\hline Facebook & Ferreyros & Modasa & Cummis \\
\hline Fans & 150 000 & 14000 & 19000 \\
\hline Contenido & $\begin{array}{l}\text { Información interna de } \\
\text { la empresa, contenido } \\
\text { motivacional, fechas } \\
\text { festivas y logros de la } \\
\text { empresa. }\end{array}$ & $\begin{array}{l}\text { Información interna de } \\
\text { la empresa, contenido } \\
\text { motivacional, fechas } \\
\text { festivas, logros de la } \\
\text { empresa y productos de } \\
\text { la empresa. }\end{array}$ & $\begin{array}{l}\text { Información interna de } \\
\text { la empresa, } \\
\text { presentación de } \\
\text { productos. }\end{array}$ \\
& Media & Media & Alta \\
\hline Interacción & Cada 3 o 4 días & Diario & Diario \\
\hline Frecuencia & \multicolumn{2}{|l}{} \\
\hline
\end{tabular}

Estas son ejemplos de publicación del fanpage de cada competidor: 


\section{Figura 1.5}

\section{Publicación de Facebook de Ferreyros}

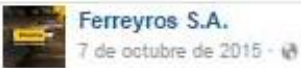

En Rentafer ofrecemos grupos electrógenos en alquiler con las mejores ventajas del mercado: Soporte en el mismo lugar de operación, grupos encapsulados e isonorizados o abiertos, sistema de Monitoreo Satelital Product Link, entre otros. Puede enviamos sus consultas o requerimientos en el siguiente enlace: http://bit.ly/contacto_rentafer

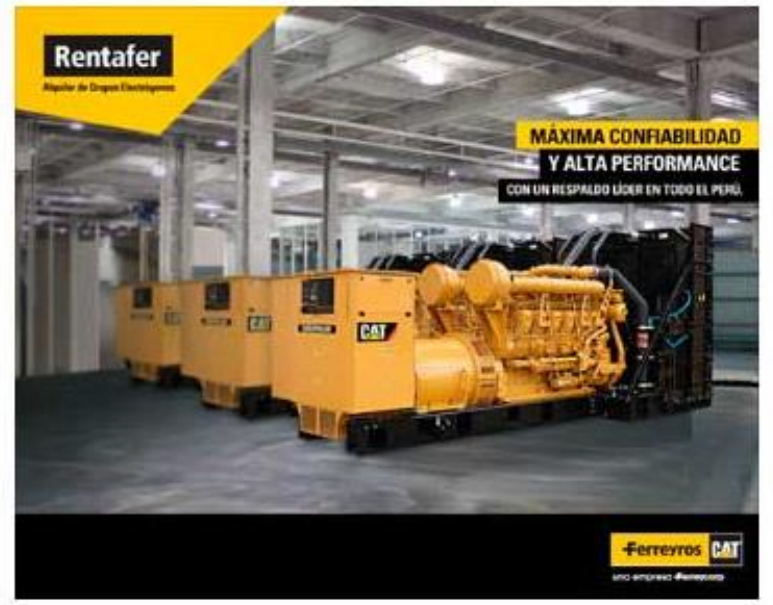

If Me gusta E Comentar + Compartir E * $\ldots$

Fuente: Captura de pantalla Octubre 2015.

\section{Figura 1.6}

Publicación de Facebook de Modasa

-1. MODASA | Motores Diesel Andinos S.A.

6. 13 de septiembre a las 9:00-6

No importan las condiciones de altura o temperatura. Conoce cómo adquirir un Grupo Electrógeno CUMMINS aqui: http://goo. gl/icHhxt \#Modasa

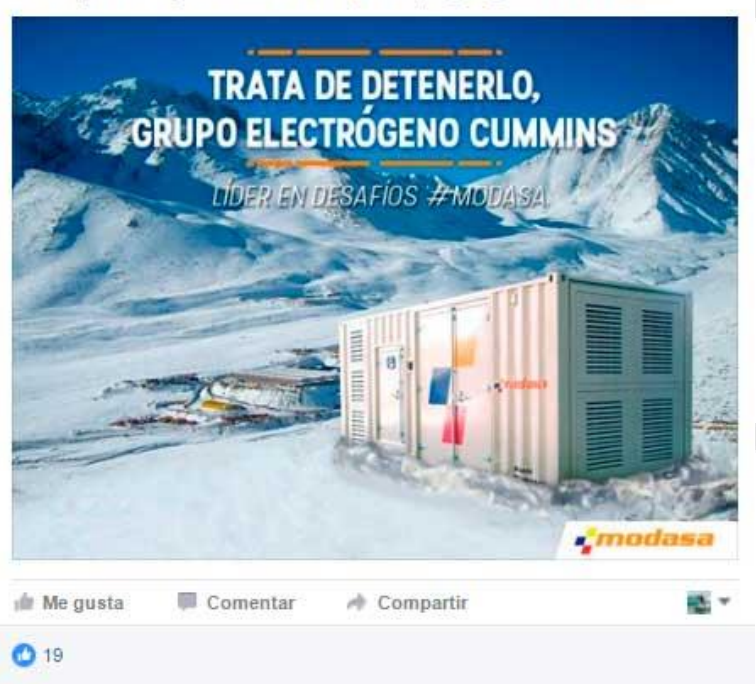

Fuente : captura de pantalla Septiembre 2015. 
Figura 1.7

Publicación Facebook de Cummis.

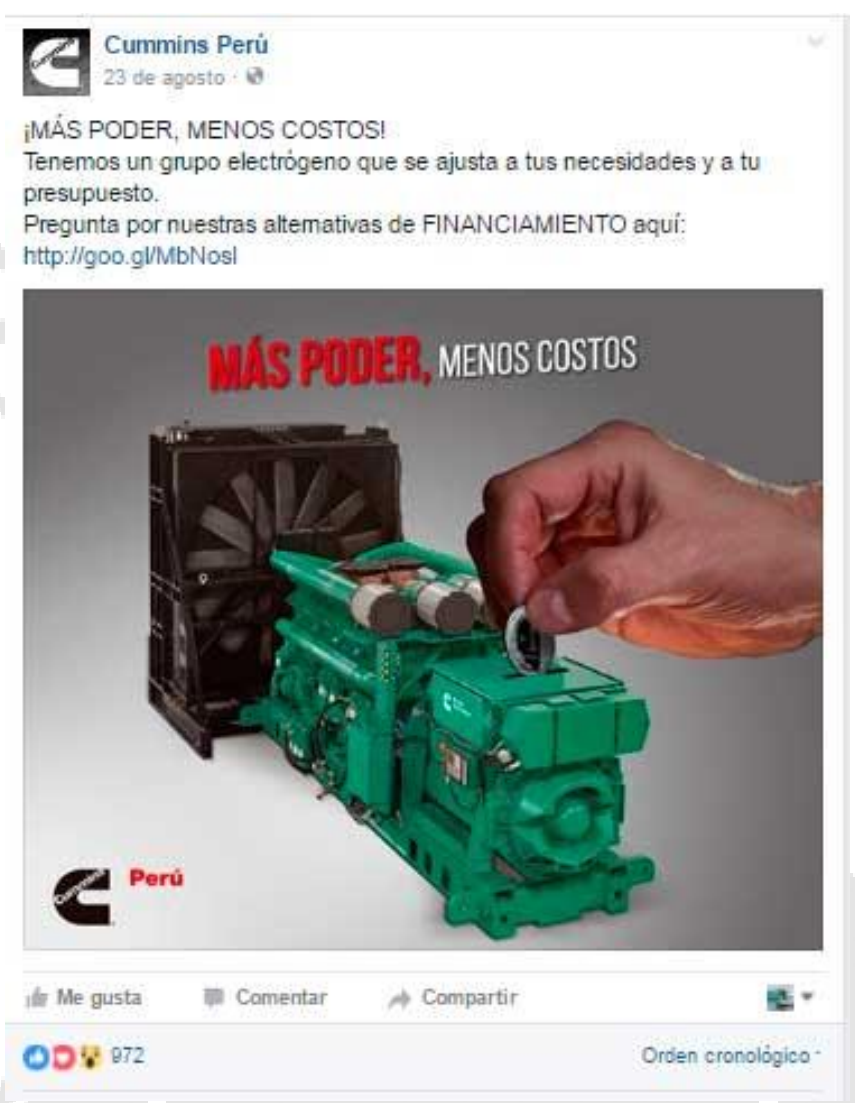

Fuente: Captura de pantalla de Facebook Agosto 2016.

Como se puede apreciar en este análisis el contenido publicado en las redes sociales de la competencia es bastante similar y todos tienen una cantidad de fans importante. La frecuencia de publicación también es constante. Se puede apreciar buen diseño gráfico en las imágenes de sus publicaciones y textos concisos en la descripción.

Se analizó la página de Facebook de cada competidor por medio del sitio web fanpagekarma por el periodo de un mes (Noviembre 2015) para analizar mejor las métricas de cada fanpage. 
Figura 1.8

Métricas del Facebook de los competidores.

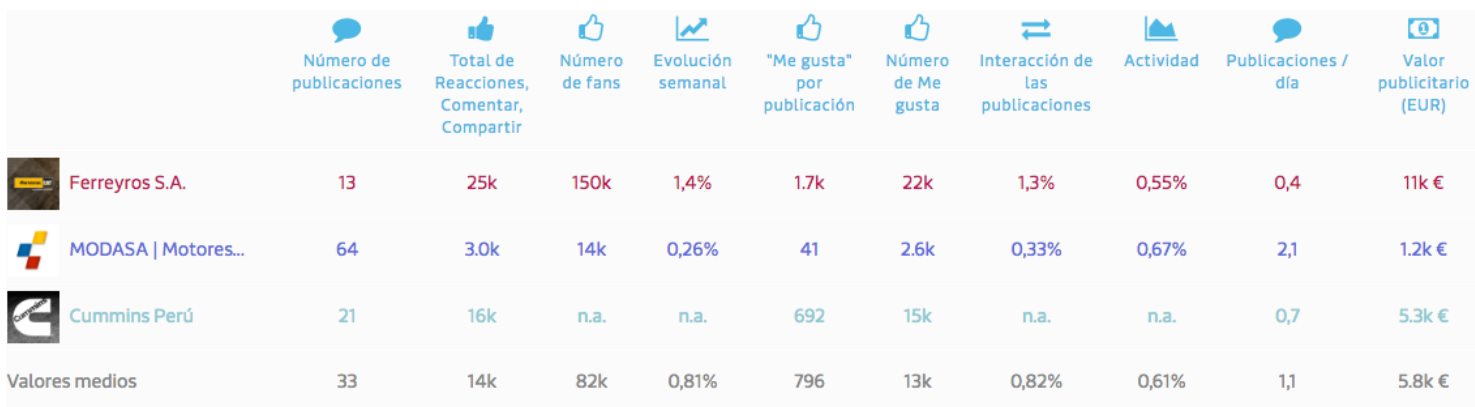

Fuente: Sitio web Fanpagekarma

Como se puede apreciar en este cuadro la inversión mensual para Facebook de los tres principales competidores es considerable, siendo Ferreyros la empresa que mayor invierte. Modasa tiene mucha más frecuencia de publicación pero menos participación de los usuarios. Ferreyros no publica constantemente pero la participación de los usuarios es mucho más alta debido a la gran cantidad de pauta que coloca a sus publicaciones.

\subsubsection{Análisis LinkedIn Enero 2015.}

Cuadro comparativo del LinkedIn de los competidores:

Tabla 1.3

Análisis del LinkedIn de los competidores

\begin{tabular}{|l|l|l|l|}
\hline & Ferreyros & Modasa & Cummis \\
\hline Seguidores & 28000 & 1359 & 371 \\
\hline Contenido & $\begin{array}{l}\text { Información interna de } \\
\text { la empresa, } \\
\text { presentación de } \\
\text { productos y } \\
\text { certificaciones } \\
\text { obtenidas. }\end{array}$ & $\begin{array}{l}\text { Información interna de } \\
\text { la empresa, contenido } \\
\text { motivacional, fechas } \\
\text { festivas, logros de la } \\
\text { empresa y productos de } \\
\text { la empresa. }\end{array}$ & $\begin{array}{l}\text { Información interna de } \\
\text { la empresa, } \\
\text { presentación de } \\
\text { productos. }\end{array}$ \\
\hline Interacción & Media & Media & Media \\
\hline Frecuencia & $\begin{array}{l}\text { 2 veces al mes } \\
\text { aproximadamente }\end{array}$ & Diario & Diario \\
\hline
\end{tabular}

Estas son ejemplos de publicación de LinkedIn de los tres competidores: 


\section{Figura 1.9}

\section{Publicación de LinkedIn de Modasa}

MODASA | Motores Diesel Andinos S.A. Ponemos a tu disposición nuestras pruebas dinamométrica de alta gama para diferentes tipos de motores de hasta $600 \mathrm{hp}$. Obtén más información llamando al: Telf: +(51 1) 6158500 \#Modasa

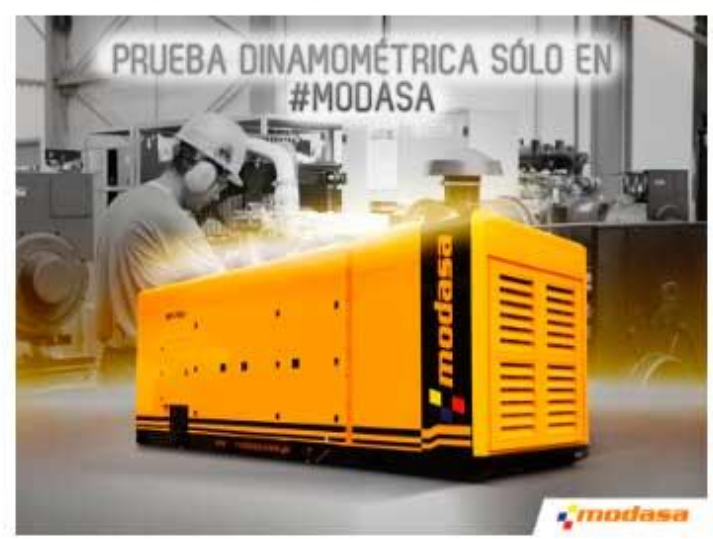

Recomendaciones (4) - Comentar - Compartir * Hace 2 dias

Juan Carlos Laguna Mendoza, Jorge Lúcar Cadillo +2

Fuente: Captura de pantalla Enero 2015.

Figura 1.10

Publicación de LinkedIn de Cummis

Cummins Perú Con su vasta experiencia en ingeniería, Cummins ha desarrollado lo último en turbo tecnologia. \#Cummins, trabajando cada dia para ofrecerte lo mejor y lo último en tecnologias para tu motor. Más, aquí: http.//goo.gl/xljXAa

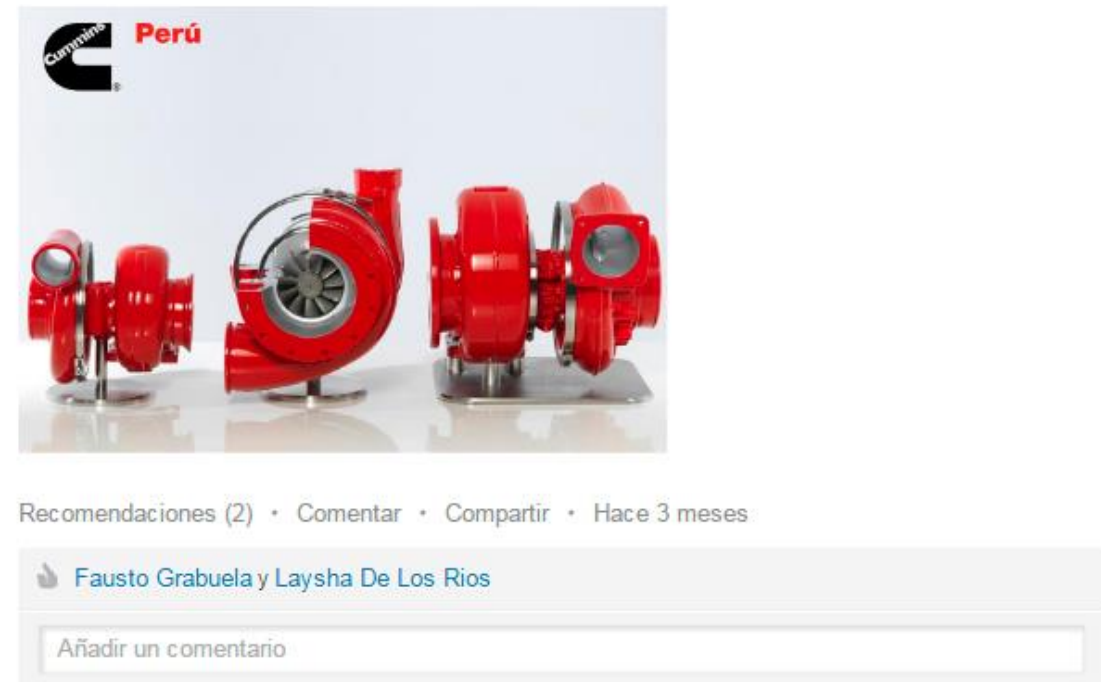

Fuente: Captura de pantalla Enero 2015. 
Figura 1.11

Publicación LinkedIn Ferreyros

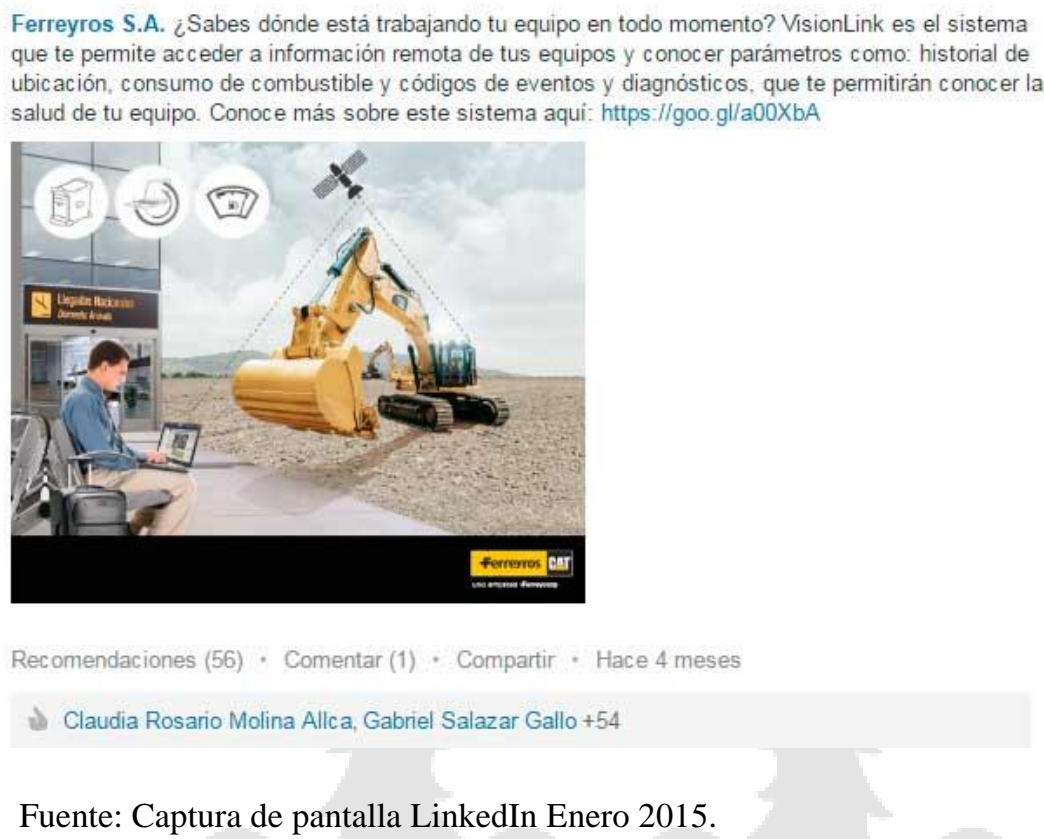

Fuente: Captura de pantalla LinkedIn Enero 2015.

Como se puede apreciar al igual que Facebook el contenido mostrado en LinkedIn es bastante similar en las tres empresas. En el caso de Ferreyros la frecuencia de publicación es bastante baja a comparación de Cummis y Modasa pero su interacción es igual que los demás competidores debido a la gran cantidad de seguidores.

Las tres empresas tienen buen diseño gráfico en sus publicaciones, el texto en el encabezado no es muy extenso y colocan siempre un enlace que direcciona a su sitio web como estrategia SEO.

\subsection{FODA}

Se realizó un FODA general de la empresa y uno comunicacional para conocer la situación de Provejec en estos dos aspectos y a partir de este análisis plantear las estrategias del plan de social media.

El método utilizado para elaborar los FODA fue la observación del modo de operación de la empresa y el brochure. También se realizó entrevistas informales no estructuradas a la gerencia general, los jefes de áreas y colaboradores. 


\subsubsection{FODA GENERAL}

Tabla 1.4

FODA general de Provejec.

Fortalezas

- Experiencia de 19 años en el sector.

- Excelente post-venta y servicio integral.

- Personal capacitado en las sucursales de los proveedores del extranjero.

- Sólida reputación en el sector.

- Stock de productos

- Servicio post-venta en todo el territorio nacional.

\section{Oportunidades}

- Nuevas oportunidades de negocio con el "boom inmobiliario".

- Respaldo sólido de los proveedores extranjeros.

- Debido al fenómeno el niño muchas empresas del norte requieren grupos electrógenos para sus planes de contingencia.

\section{Debilidades}

- Centralización en la toma de decisiones en gerencia general.

- Poca presencia en internet de la marca.

- Desorganización en los procesos de la empresa.

- Lenta respuesta a las solicitudes de cotización.

\section{Amenazas}

- Incertidumbre en el mercado por próximas elecciones.

- Estancamiento de proyectos por la espera del cambio de gobierno y la crisis económica mundial.

- Competencia con precios muy reducidos debido a la procedencia china de los productos. 


\subsubsection{FODA COMUNICACIONAL}

Tabla 1.5

FODA comunicacional de Provejec.

\begin{tabular}{|c|c|}
\hline $\begin{aligned} & \text { Fortalezas } \\
& \bullet \quad \text { Inclusión de personal } \\
& \text { especializado en } \\
& \text { marketing. } \\
& \bullet \quad \text { Destinación de } \\
& \text { presupuesto para mejorar } \\
& \text { el marketing digital. } \\
& \text { - } \text { Buena relaciones } \\
& \text { comerciales con los } \\
& \text { clientes. }\end{aligned}$ & $\begin{array}{ll}\text { Debilidades } \\
\text { - } & \text { Inexistente área de } \\
& \text { marketing en la empresa. } \\
\text { - } & \text { Pobre diseño gráfico del } \\
& \text { brochure. empresarial. } \\
\text { - } & \text { Inexistente identidad } \\
& \text { visual. } \\
\text { - } & \text { Diferentes logotipos en } \\
\text { - } & \text { los materiales gráficos. } \\
\text { Escasa presencia de la } \\
\text { - } \\
\text { marca en internet. } \\
\text { Sitio web muy básico. }\end{array}$ \\
\hline $\begin{array}{ll}\text { Oportunidades } \\
\qquad \begin{array}{l}\text { Herramientas de análisis } \\
\text { estadísticas gratuitas. }\end{array}\end{array}$ & $\begin{aligned} & \text { Amenazas } \\
& \bullet \quad \text { Mayor inversión en } \\
& \text { marketing digital de la } \\
& \text { competencia. } \\
& \text { - } \text { Identidad corporativa } \\
& \text { sólida de la competencia. } \\
& \text { - } \begin{array}{l}\text { Empresas pequeñas del } \\
\text { rubro optan por tener } \\
\text { presencia en internet. }\end{array}\end{aligned}$ \\
\hline
\end{tabular}

\subsection{Conclusiones del diagnóstico.}

Se llegó a la conclusión que los competidores directos de Provejec si tienen una buena presencia en social media. La mayoría presenta buena arquitectura de la información y excelente experiencia del usuario en sus sitios web. En redes sociales presentaban temas similares de publicación y la frecuencia de publicación es constante. Los tres competidores principales tienen un presupuesto considerable de inversión en redes sociales.

Por otro lado, Provejec no tenía buena presencia en internet. Su sitio web era muy básico, sin una estructura definida y un pobre diseño gráfico. En redes sociales no presentaba un plan de contenidos definido y no había buen diseño gráfico en sus publicaciones. No contaba con buenas prácticas SEO y no tenía anuncios en los buscadores. 


\section{CAPÍTULO II: SOCIAL MEDIA PLAN}

Luego del análisis de la situación de Provejec en internet y de los principales competidores. Se procedió a plantear los objetivos de la estrategia digital y el plan de social media.

\subsection{Público objetivo.}

Antes de plantear el plan de social media era de suma importancia definir al público objetivo de Provejec, que al dedicarse a la comercialización de grupos electrógenos y todo lo relacionado al rubro, los potenciales clientes son empresas de todos los sectores en todo el Perú. Se definió al público objetivo como personas entre 23 y 55 años que trabajan en pequeñas, medianas y grandes empresas que normalmente busquen el requerimiento del grupo electrógeno o tomen la decisión de compra y que sean:

- Dueños de empresas

- Jefe de obra.

- Gerente General

- Gerente de ventas

- Jefe de ventas

- Jefe de logística.

- Jefe de mantenimiento.

- Asistente de mantenimiento.

- Asistente de logística.

- Ingenieros

- Ingenieros Eléctricos

- Arquitectos.

- Asistente de gerencia.

- Jefe de compras.

- Asistente de compras.

- Electricistas.

- Administrativos.

- Secretarias. 
- Ejecutivos comerciales.

\subsection{Objetivos}

Luego de definir al público objetivo y el análisis del diagnóstico de Provejec en internet se procedió a definir los objetivos generales de la estrategia digital:

- Mejorar la presencia digital de la marca.

- Generar tráfico al sitio web para obtener solicitudes de cotización.

\subsection{Matriz del Social Media Plan}

Para García (2012) en base a los objetivos planteados para el plan de social media se tiene que definir estrategias y posteriormente acciones. Es por esto que se planteó una matriz en base a los objetivos trazados.

Tabla 2.1

Matriz Social Media

\begin{tabular}{|c|c|c|}
\hline Objetivos Social Media Plan & Estrategias & Acciones \\
\hline $\begin{array}{l}\text { Mejorar la presencia digital de } \\
\text { la marca. }\end{array}$ & $\begin{array}{l}\text { - Diseñar un nuevo sitio } \\
\text { web. }\end{array}$ & $\begin{array}{l}\text { - Plantear nueva estructura } \\
\text { de la información. } \\
\text { - Que el sitio tenga una } \\
\text { buena experiencia del } \\
\text { usuario. } \\
\text { - Que el sitio web sea } \\
\text { accesible. } \\
\text { - Que el sitio tenga buen } \\
\text { diseño gráfico. } \\
\text { Mostrar los casos de } \\
\text { éxito de la empresa en el } \\
\text { sitio web. } \\
\text { Plantear temáticas de } \\
\text { contenidos relacionados } \\
\text { al rubro. }\end{array}$ \\
\hline
\end{tabular}




\begin{tabular}{|c|c|c|}
\hline & $\begin{array}{l}\text { Tener presencia en redes } \\
\text { sociales (Facebook, } \\
\text { LinkedIn). }\end{array}$ & 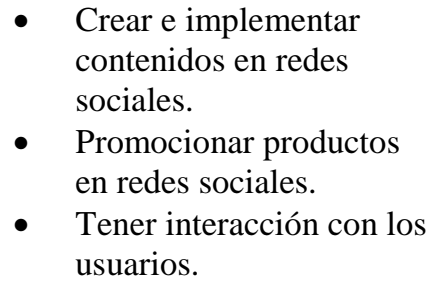 \\
\hline \multirow[t]{4}{*}{$\begin{array}{l}\text { Generar tráfico al sitio web } \\
\text { para obtener solicitudes de } \\
\text { cotización. }\end{array}$} & - $\quad$ Estrategias SEO offpage. & $\begin{array}{ll}\text { - } & \text { Linkbuilding. } \\
\text { - } & \text { Hacer marketing viral. }\end{array}$ \\
\hline & - Estrategias SEO onpage. & $\begin{array}{l}\text { - } \begin{array}{l}\text { Creación de contenidos } \\
\text { audiovisual en el sitio } \\
\text { web. }\end{array} \\
\text { - } \quad \text { Que el sitio web tenga } \\
\text { administración de } \\
\text { contenidos. } \\
\text { - Incluir los principales } \\
\text { metatag en el sitio web. } \\
\text { - Incluir palabras clave de } \\
\text { los principales productos } \\
\text { al sitio web. } \\
\text { - Optimizar tiempo de } \\
\text { descarga del sitio web. } \\
\text { Que el sitio web tenga un } \\
\text { formulario de contacto. } \\
\text { - Implementar un chat en } \\
\text { el sitio web. }\end{array}$ \\
\hline & - $\quad$ Publicidad SEM. & $\begin{array}{ll}\text { - Diseñar campaña de } \\
\text { anuncios pagados } \\
\text { (Google Adwords) }\end{array}$ \\
\hline & $\begin{array}{l}\text { - Publicidad en Redes } \\
\text { sociales. }\end{array}$ & $\begin{array}{ll}\text { - } & \text { Linkbuilding. } \\
\text { - } & \text { Segmentar y colocar } \\
\text { pauta a las publicaciones } \\
\text { por redes sociales. } \\
\text { - } & \text { Hacer marketing viral. } \\
\text { - } & \text { Contestar consultas por } \\
\text { medio de las redes } \\
\text { sociales. }\end{array}$ \\
\hline
\end{tabular}


Era necesario tener un nuevo sitio web y tener presencia en redes sociales para estar a la par con los competidores. Se solicitó a la gerencia general un presupuesto para invertir en redes sociales. Se logró obtener 100 dólares mensuales para la publicidad por redes sociales. El presupuesto se dividió en la mitad de inversión para Facebook y la otra mitad para LinkedIn. Se aprobó también un presupuesto para subcontratar una agencia especializada en la programación de un nuevo sitio web. También se subcontrató a una agencia que administrara la cuenta de GoogleAdwords bajo la supervisión del autor de este proyecto. 


\section{CAPÍTULO III: NUEVO SITIO WEB DE PROVEJEC}

\subsection{Desarrollo del nuevo sitio web.}

El autor de este proyecto fue el estratega de la nueva estructura del sitio web y de la arquitectura de la información. Se subcontrató a una agencia para que se encargue de los aspectos técnicos como la programación y el diseño del sitio web.

\subsubsection{Diseño. Nueva estructura y arquitectura de la información.}

Se planteó un nuevo sitio web con una nueva estructura de la información. La nueva estructura está conformada por 6 secciones:

- Home: Página principal de la empresa se muestra la diferenciación de la empresa y los productos principales.

- Nosotros: Se muestra misión y visión de la empresa y los valores corporativos.

- Servicios: Muestra los servicios que ofrece la empresa.

- Casos de éxito: Principales proyectos exitosos de la empresa.

- Provejec tv: Videos relacionados con la empresa.

- Contacto: Formulario de contacto y mapa de los locales de la empresa. 
Esta es la estructura que se planteó para el sitio web:

Figura 3.1

Sitemap Provejec.

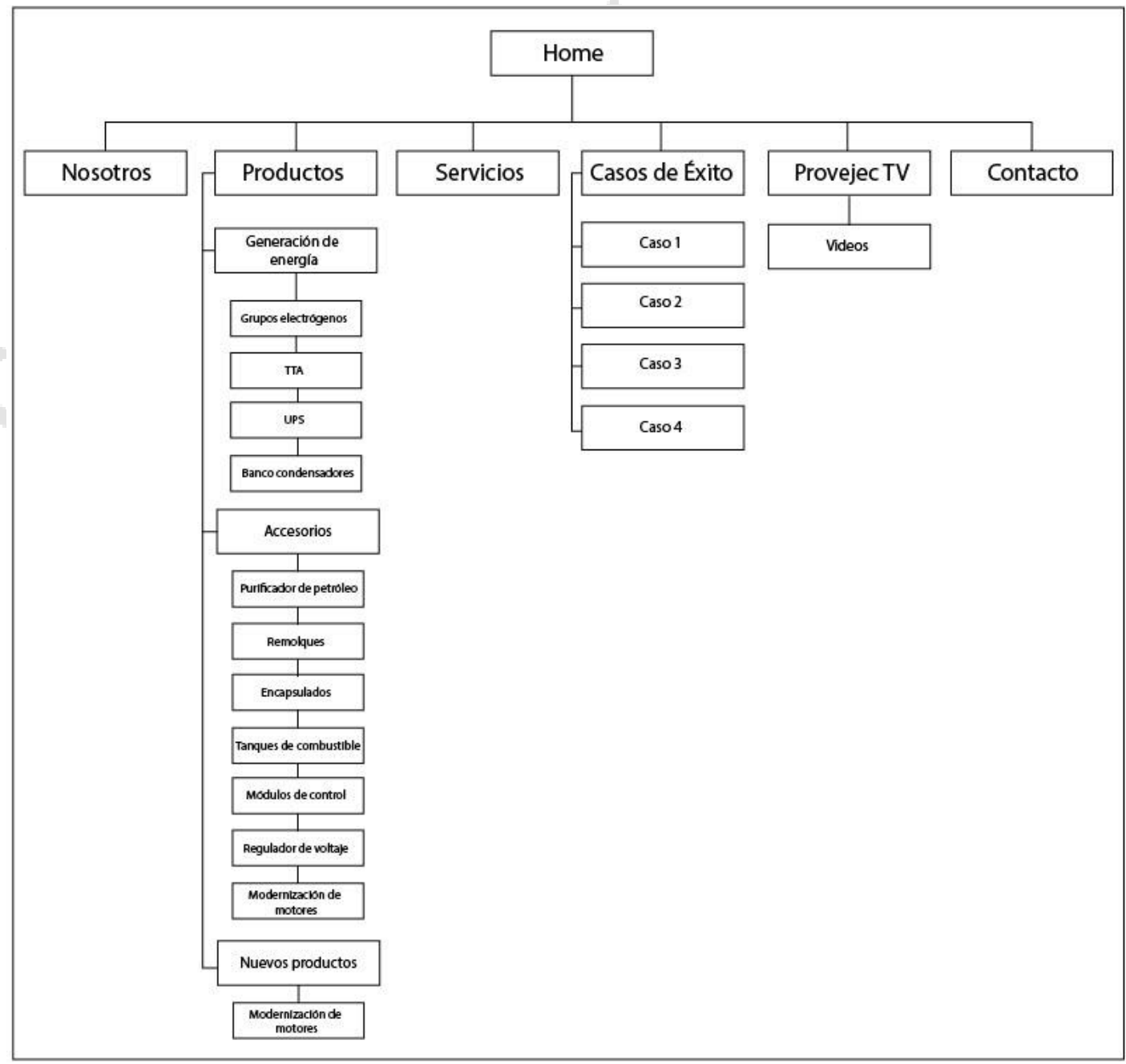

Fuente: elaboración propia.

La página home es la página principal del sitio web. Se implementaron tres banners para colocar información importante de la empresa. En el primero se colocó un lema con la palabra clave "grupos electrógenos" y una imagen relacionada. En el segundo banner se colocó una frase relacionada al servicio post-venta de la empresa que es la diferenciación con respecto a la competencia y una imagen relacionada. En el tercer banner se colocó una frase para presentar las marcas de motores que distribuye la empresa con la imagen de un grupo electrógeno y al costado los logotipos de la marcas de los motores de los grupos electrógenos. 
Debajo de los banners se colocó cinco imágenes de los productos principales de la empresa que son botones que direccionan a la página de estos productos. Debajo se colocó una iconografía y un texto describiendo la diferenciación de Provejec. Y por último se colocó una barra horizontal con los logotipos de los principales y más importante clientes de Provejec.

Figura 3.2

Página principal y primer banner del sitio web de Provejec.

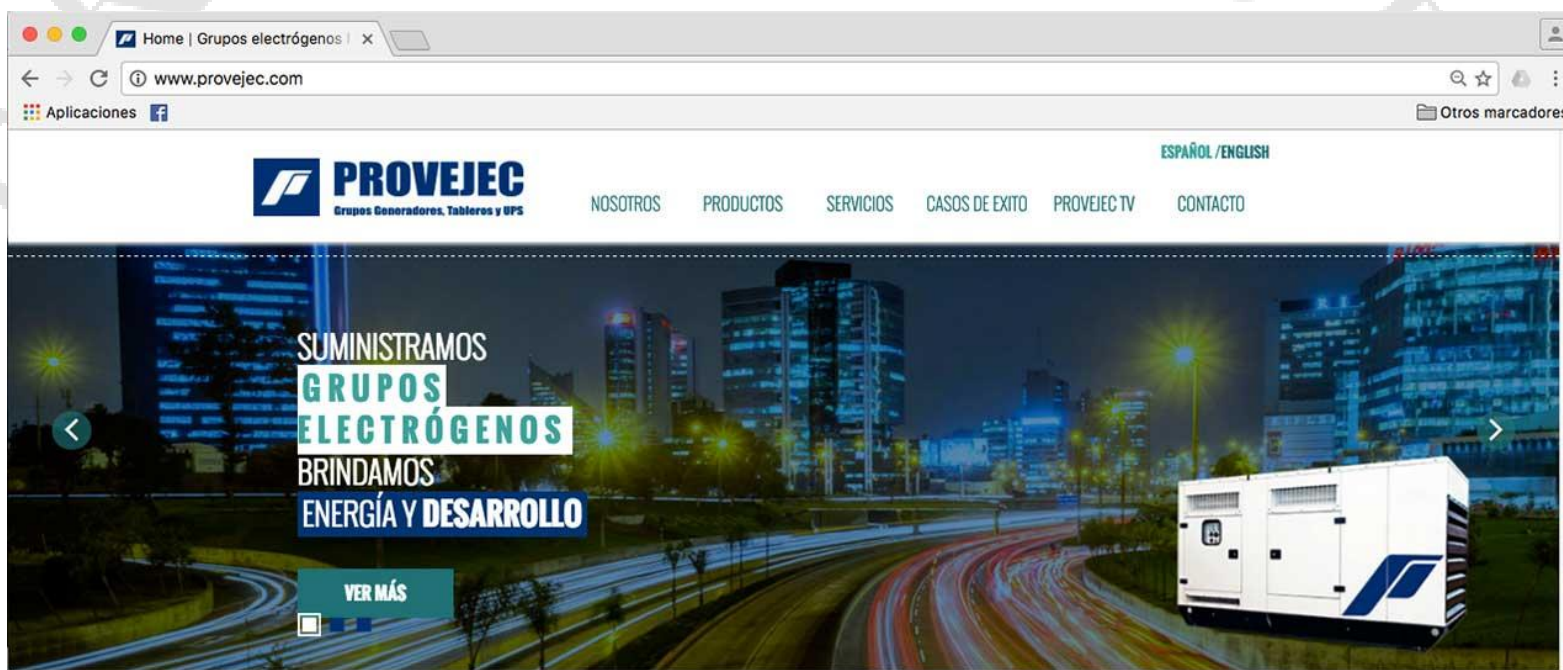

\section{- NUESTROS PRODUCTOS -}

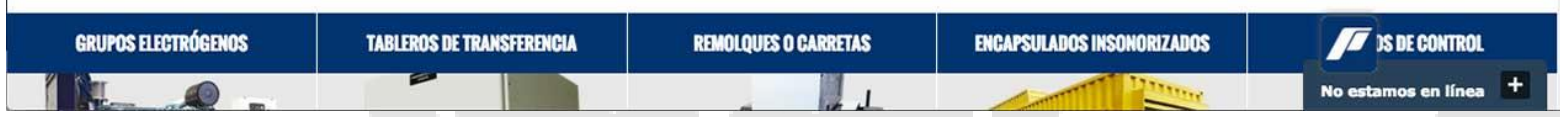

Fuente: Captura de pantalla 
Figura 3.3

Segundo banner de la página home.

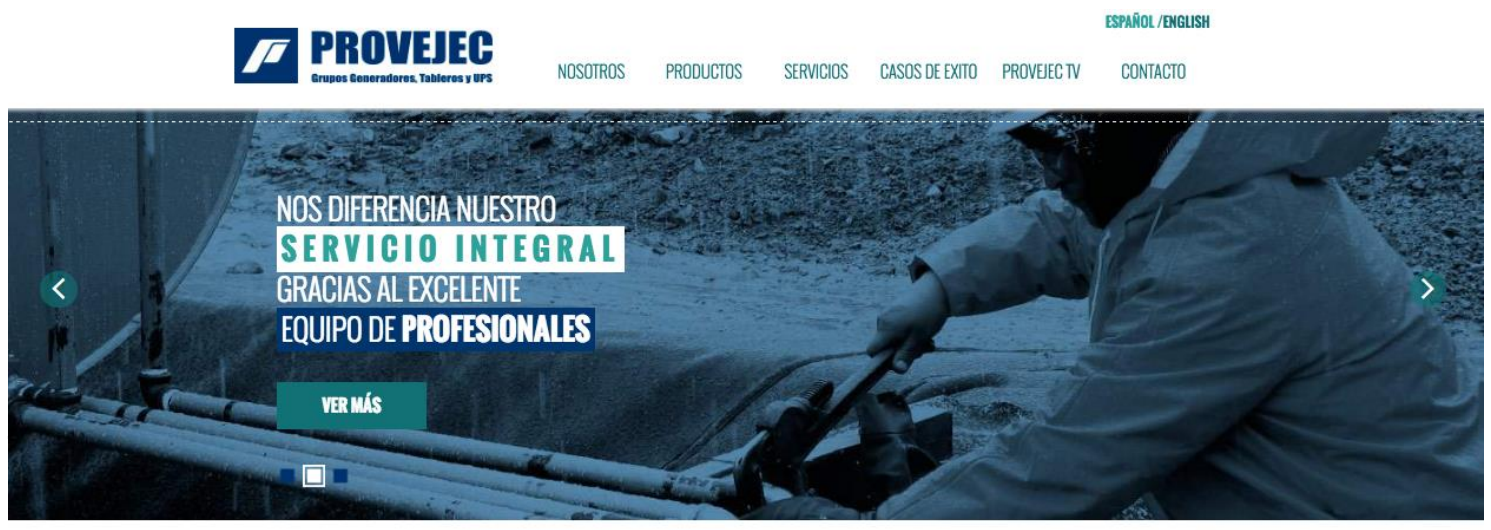

\section{- NUESTROS PRODUCTOS -}

Fuente: Captura de pantalla.

Figura 3.4

Tercer banner de la página home.

\section{PROVEJEC}

NOSOTROS PRODUCTOS SERVIGIOS CASOSDEEXTO PROVEEETV CONTACTO

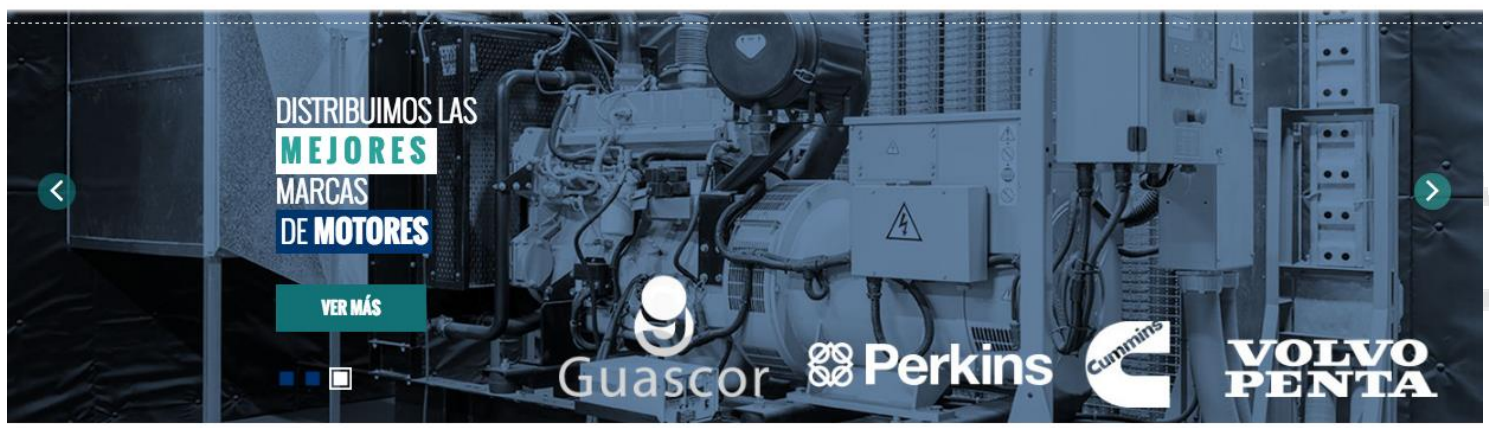

- NUESTROS PRODUCTOS -

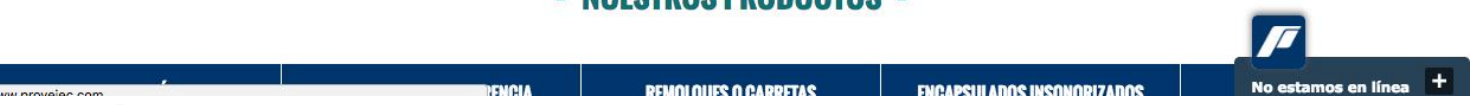

Fuente: captura de pantalla. 
Figura 3.5

Segunda parte de la página home.

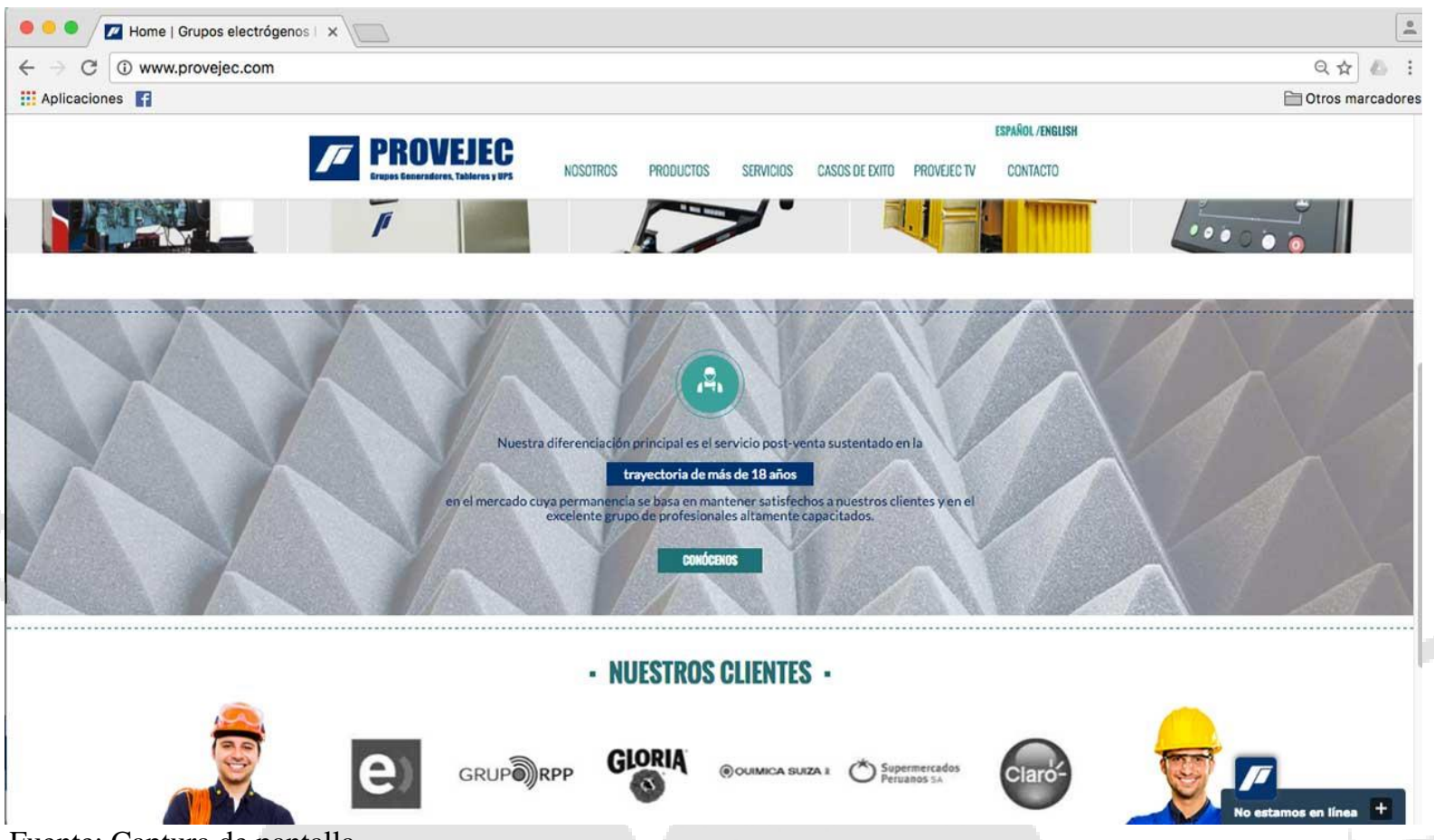

Fuente: Captura de pantalla.

En la página Nosotros se colocó una imagen de los colaboradores en una planta de producción con la frase "Nosotros Brindamos Desarrollo". Debajo la misión y la visión de la empresa y posteriormente iconografías de los valores de la empresa con un corto texto descriptivo. 
Figura 3.6

Página nosotros.

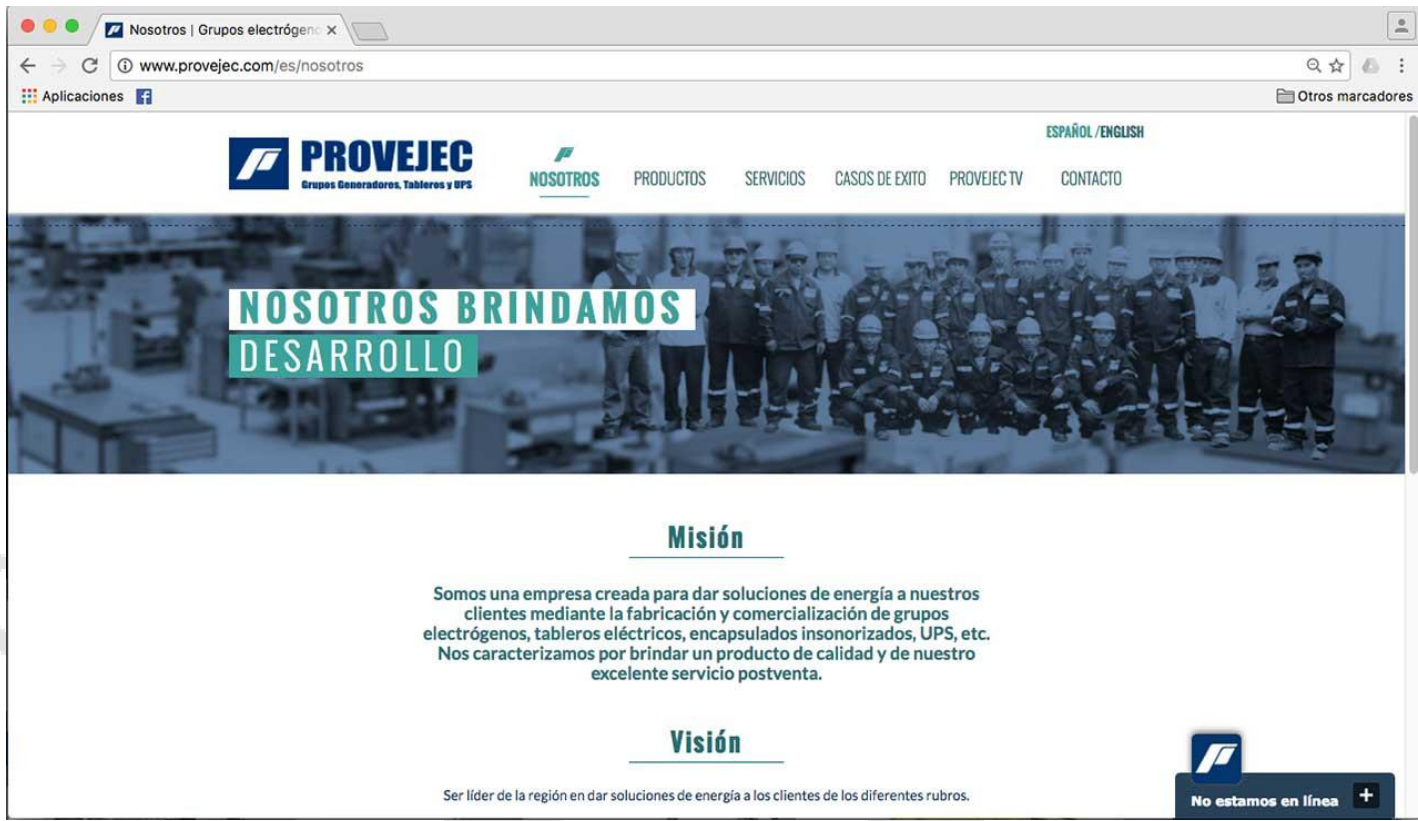

Fuente: captura de pantalla.

En la página de productos se colocó una imagen de los colaboradores de la empresa trabajando con la frase "nuestros productos de la mejor calidad". Luego de analizar los tipos de productos, se procedió a colocar las siguientes categorías:

- Generación de energía (A):

○ Grupos electrógenos.

- Tableros de transferencia.

- Banco condensadores.

- Tableros de transferencia.

- Accesorios (B):

○ Módulos de control.

- Carretas.

- Encapsulados insonorizados.

- Tanques de combustible.

- Purificador de petróleo y aceite.

- Modernización de motores.

- Regulador de voltaje. 
- Nuevos productos (C):

- Generadores Híbridos.

Figura 3.7

Página de productos.

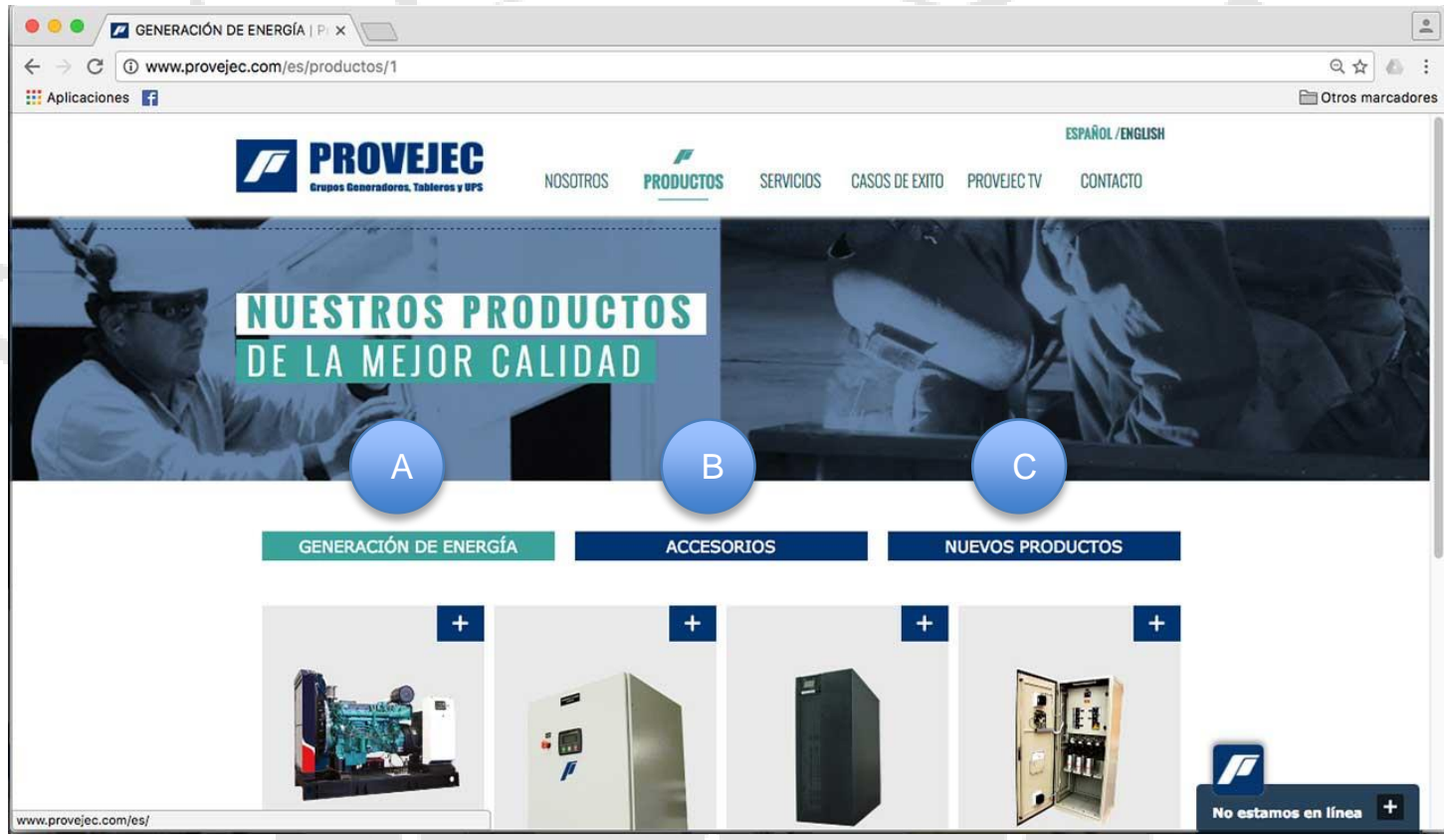

Fuente: captura de pantalla.

En cada categoría están los productos correspondientes, teniendo cada producto su página individual y en ella la descripción de estos. 
Figura 3.8

Página de producto.

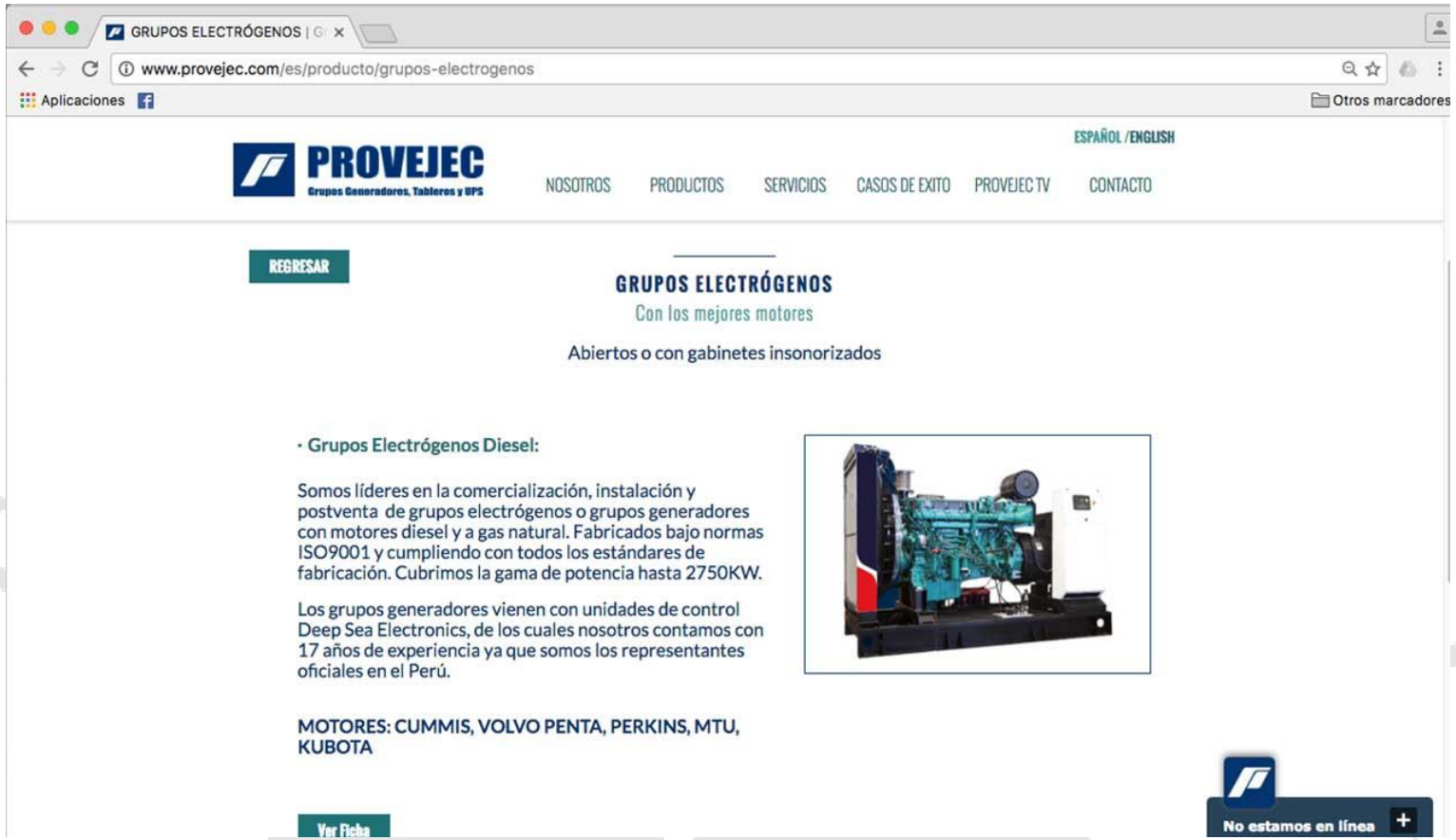

Fuente: captura de pantalla.

En la página servicios se colocó una imagen de un colaborar realizando un mantenimiento a un grupo electrógeno con la frase "nuestra diferencia el servicio postventa" y posteriormente se muestran iconografías, ver figura 3.8, que son botones de los servicios que direccionan a la descripción junto una foto relacionada. 
Figura 3.9

Página de servicios

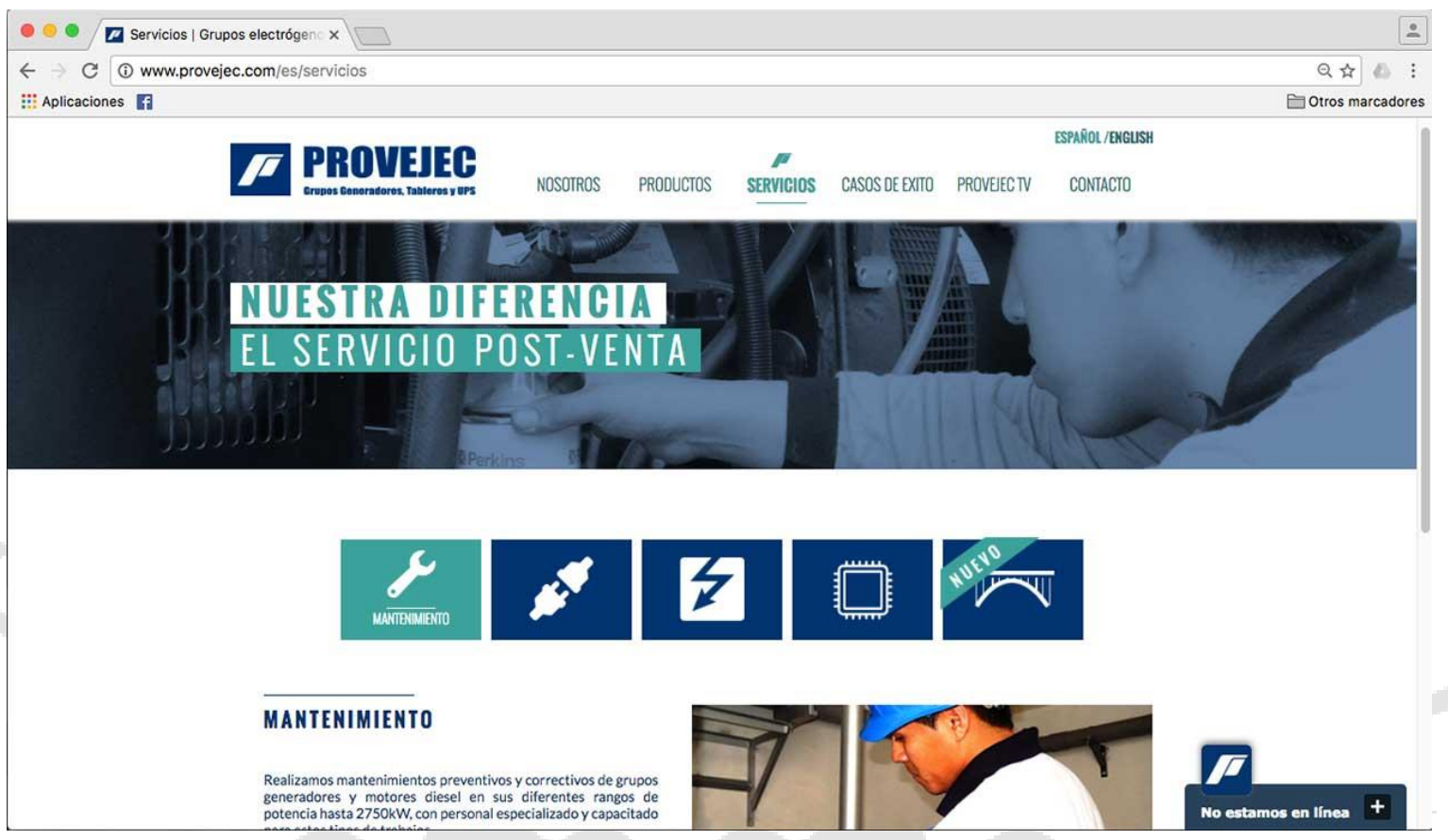

Fuente: captura de pantalla.

En la página casos de éxito se colocó una imagen de una grúa transportando un grupo electrógeno y la frase "ellos garantizan nuestro servicio". Debajo se muestran un banner con imágenes de los proyectos exitosos con una breve descripción del trabajo realizado.

Figura 3.10

Página de servicios.

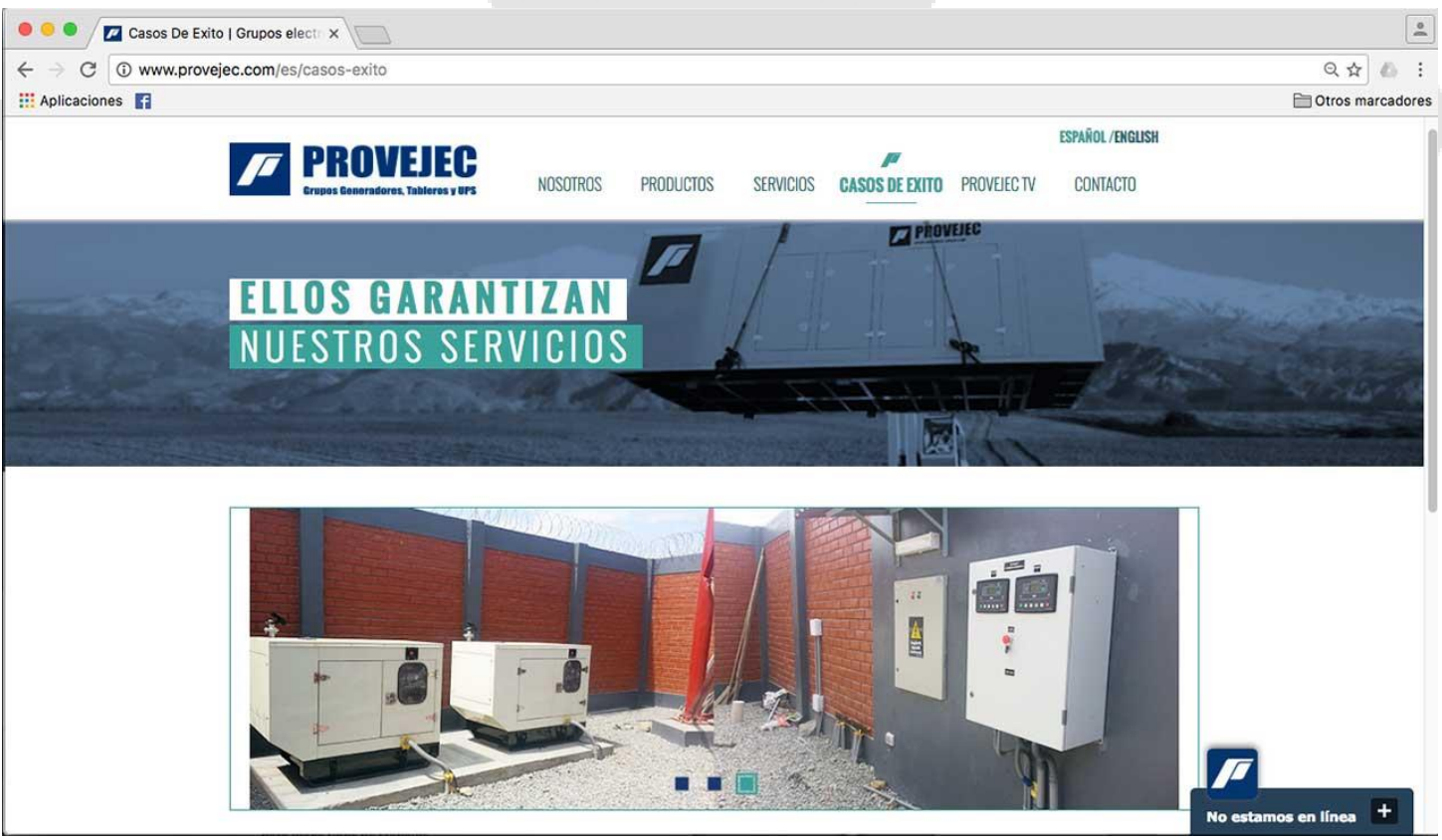


Fuente: Captura de pantalla.

En la página Provejec TV se colocó una imagen de los colaboradores de la empresa con el jefe de planta. Debajo se colocó videos relacionados a la empresa producidos por el autor de este proyecto que se encargó de la elaboración de los guiones, la producción y post-producción.

Figura 3.11

Página Provejec TV
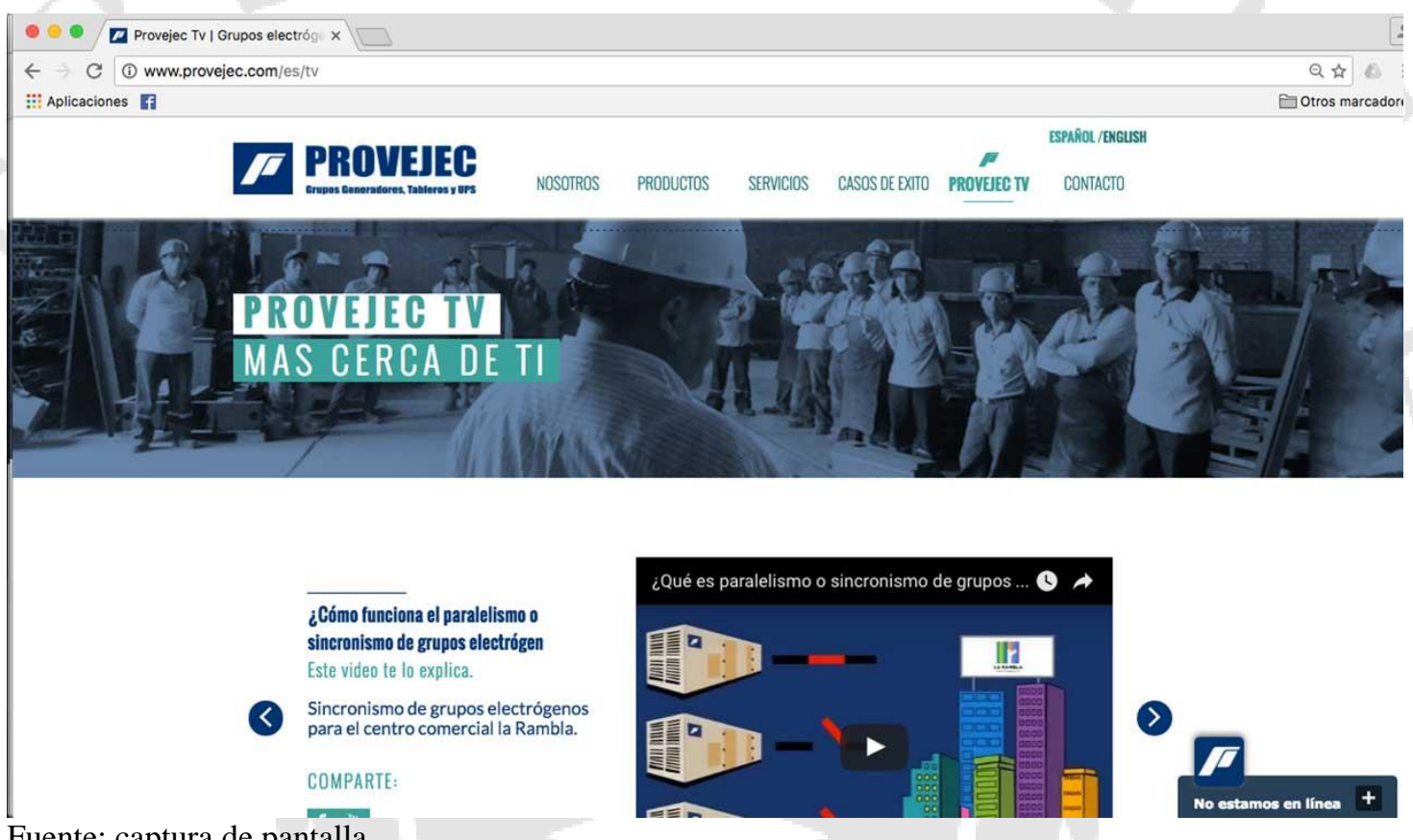

Fuente: captura de pantalla

En la página de contacto se colocó una imagen de un técnico electricista hablando por teléfono con la frase "brindamos atención de primera". Debajo un formulario, para que los usuarios puedan realizar consultas, los datos de la empresa y los mapas para llegar a los dos locales. 
Figura 3.12

Página de contacto.

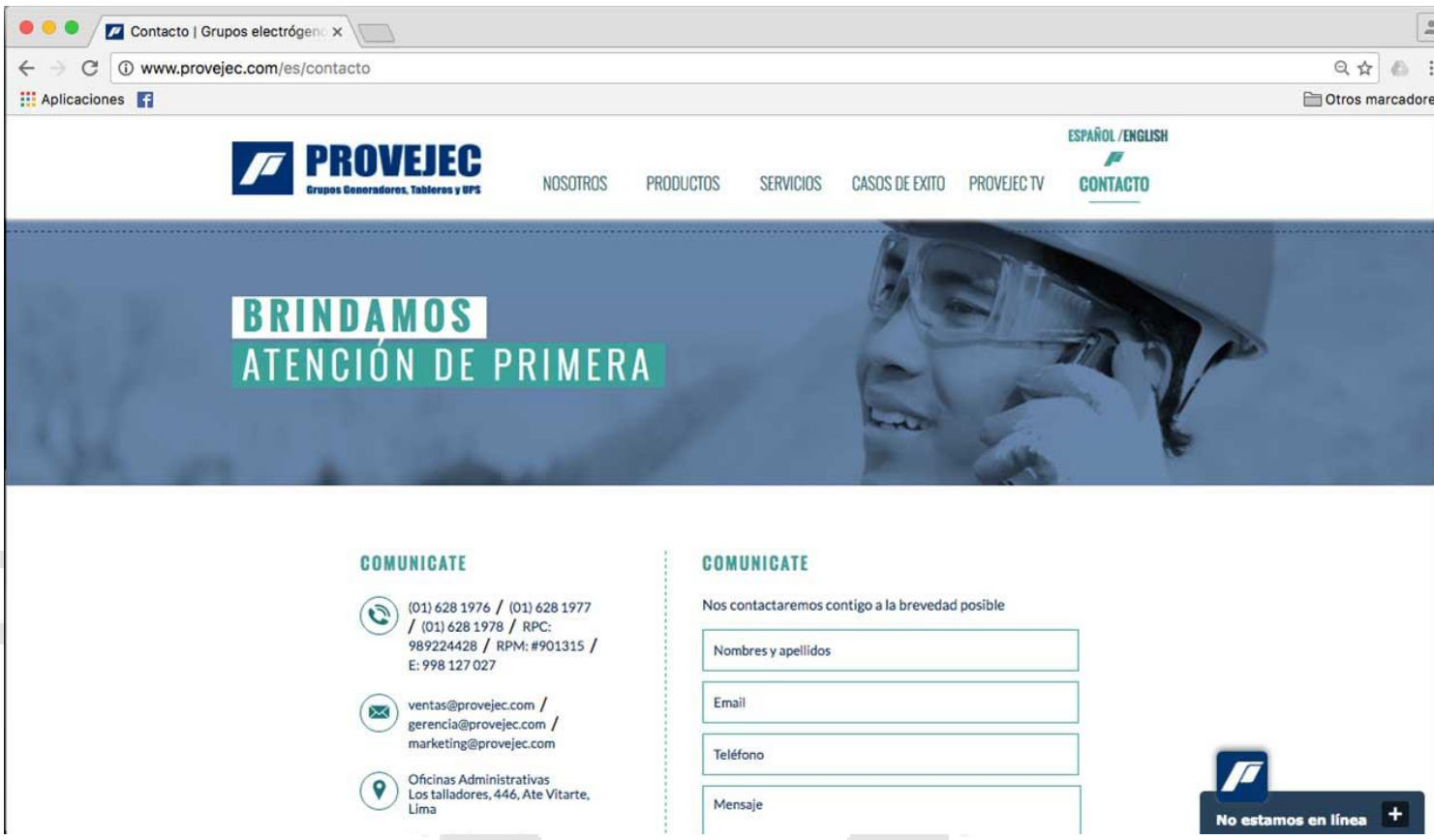

Fuente: Captura de pantalla.

\subsection{Usabilidad y experiencia del usuario}

Como vimos en la primera sección de este capítulo se distribuyó la información coherentemente de tal manera que el usuario pueda identificar cada categoría con facilidad. Según Maciá y Gosende (2010) el modelo jerárquico es ideal para los sitios web de las empresas, ya que es fácil de aprender. Es por esto que se optó por un modelo jerárquico pero con navegabilidad en red para potenciar la buena experiencia del usuario.

Jakob Nielsen (Como se citó en Chaffey y Ellis-Chadwick, 2014) afirma que si el sitio web es difícil de usar o navegar y no muestra lo que la empresa ofrece los clientes pueden abandonarlo. Es por esto que el sitio web de Provejec fue diseñado para que los clientes pudieran encontrar con facilidad y rapidez los productos de interés. El cliente o usuario puede llegar a la página de los productos principales dando un solo clic desde la página principal y puede llegar a cualquier producto con 3 clics. La página home muestra claramente el producto principal de la empresa con una imagen de un grupo 
electrógeno y la frase en el banner principal "suministramos grupos electrógenos, brindamos energía y desarrollo".

Por otro lado Maciá y Gosende (2010) plantean que el sitio web tiene que estar diseñado para los objetivos estratégicos de la empresa. En el caso del sitio web de Provejec fue diseñado para mostrar los productos y conseguir consultas o solicitudes de cotización. Los usuarios pueden realizar consultas por medio de la sección de contacto llenando un formulario simple o por medio del chat implementado se pueden comunicar instantáneamente con un asesor de la empresa y pueden realizar preguntas o solicitar cotizaciones. Los datos que los usuarios tienen que colocar en el formulario de contacto para realizar las solicitudes de cotización son: correo electrónico, celular y nombre completo. Estos datos se guardaron en los archivos de la empresa como base de datos.

Para mejorar la experiencia del usuario el menú principal se colocó en la parte superior de todas las páginas del sitio web y se implementó la función que sea estático para que el cliente no pierda tiempo en subir con el cursor si en caso requiera navegar a otra página.

Para que el usuario sepa en qué página del sitio web se encuentra se señalizó en los botones con texto en negrita. Para identificar todos los botones del sitio se implementó un efecto de tonalidad de color.

Figura 3.13

Señalización de botones.
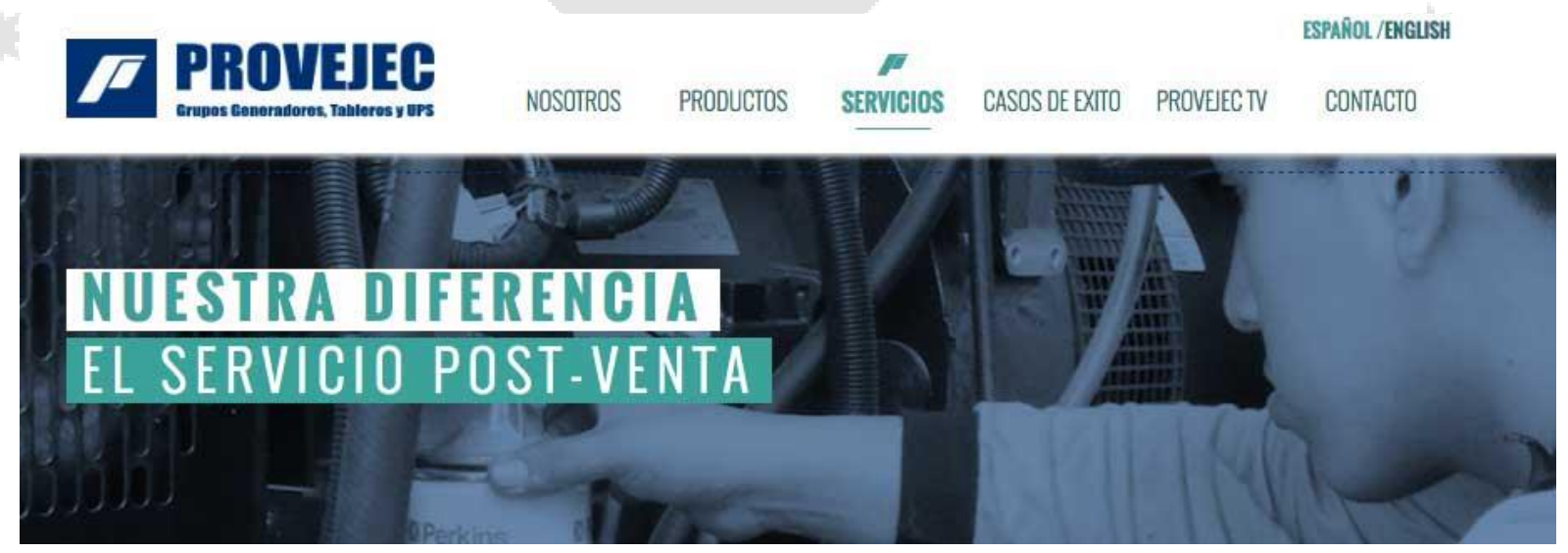

Fuente: Captura de pantalla. 
Tal como lo señala Scott (2010) las imágenes son una herramienta muy poderosa para un sitio web, ya que usualmente es lo que el usuario aprecia en primera instancia. Se colocaron imágenes de muy buena resolución y calidad acorde a la temática de cada página del sitio web.

Los textos están con palabras simples, son concisos y están descritos siguiendo una estructura piramidal, lo más importante del mensaje está primero. Se enfatizó mucho en este tema ya que normalmente la descripción de los productos industriales se utiliza muchas palabras técnicas.

Se jerarquizó la información para que los usuarios puedan diferenciar la temática de cada página web utilizando diferentes colores y tamaños de tipografía para los títulos de las diferentes páginas y categorías de productos.

Figura 3.14

Descripción de productos.

\section{Regrisen}

\section{REMOLQUES 0 CARRETAS}

Personalizados para grupos electrógenos 0 motobombas.

Fabricamos carretas de 1 eje $\circ 2$.

- Remolques o carreta para Grupos Electrógenos:

Fabricamos carretas o remolques para cualquier tipo de grupo electrógeno, motores, motobombas, subestaciones eléctricas móviles y demás maquinarias que ayudan a facilitar la movilización de estos.

Son diseñadas para el correcto funcionamiento de las máquinas.

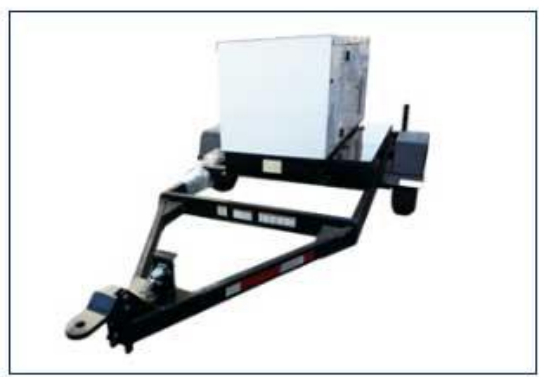

Fuente: Captura de pantalla.

\subsection{Web Autoadministrable.}

Se solicitó a la agencia encargada de la programación que el sitio web tenga un sistema de administración de contenidos para que se pueda modificar todos los elementos. Con el sistema de administración de contenidos implementado se pueden cambiar todos los 
textos de todas las páginas webs, cambiar fotos, enlaces internos, enlaces de las redes sociales, cambiar los números de teléfonos de la parte inferior. También se puede personalizar la descripción principal, los títulos y las URL.

En la página home se habilitó para poder cambiar las imágenes de los banners y las frases respectivas de cada banner y los productos principales. También poder modificar la sección que describe la diferenciación que tiene la empresa y cambiar los logotipos de los clientes más importantes.

En la página Nosotros se habilitó para cambiar los textos de la misión y visión de la empresa así como los textos descriptivos de los valores empresariales.

En la página de productos se habilitó para añadir y retirar productos de las tres categorías existentes y poder cambiar el nombre de las categorías porque en un futuro la empresa añadirá una nueva línea de productos. En cada página de los productos se puede colocar tres tipos del mismo producto y habilitar un botón para subir una ficha técnica en formato PDF.

En la página de servicios se habilitó para cambiar las iconografías de los servicios que ofrece la empresa y los textos e imágenes de cada servicio. También se puede añadir y cambiar el orden de los servicios según la relevancia.

En la página casos de éxito se puede añadir proyectos exitosos de la empresa y modificar y añadir las imágenes de cada proyecto realizado. Debajo se puede colocar un texto descriptivo de lo que se realizó en cada proyecto.

En la página de PROVEJEC TV se habilitó para añadir vídeos enlazados desde el canal de Youtube de la empresa y cambiar el texto descriptivo de los videos. 
Figura 3.15

Interfaz del administrador de contenidos

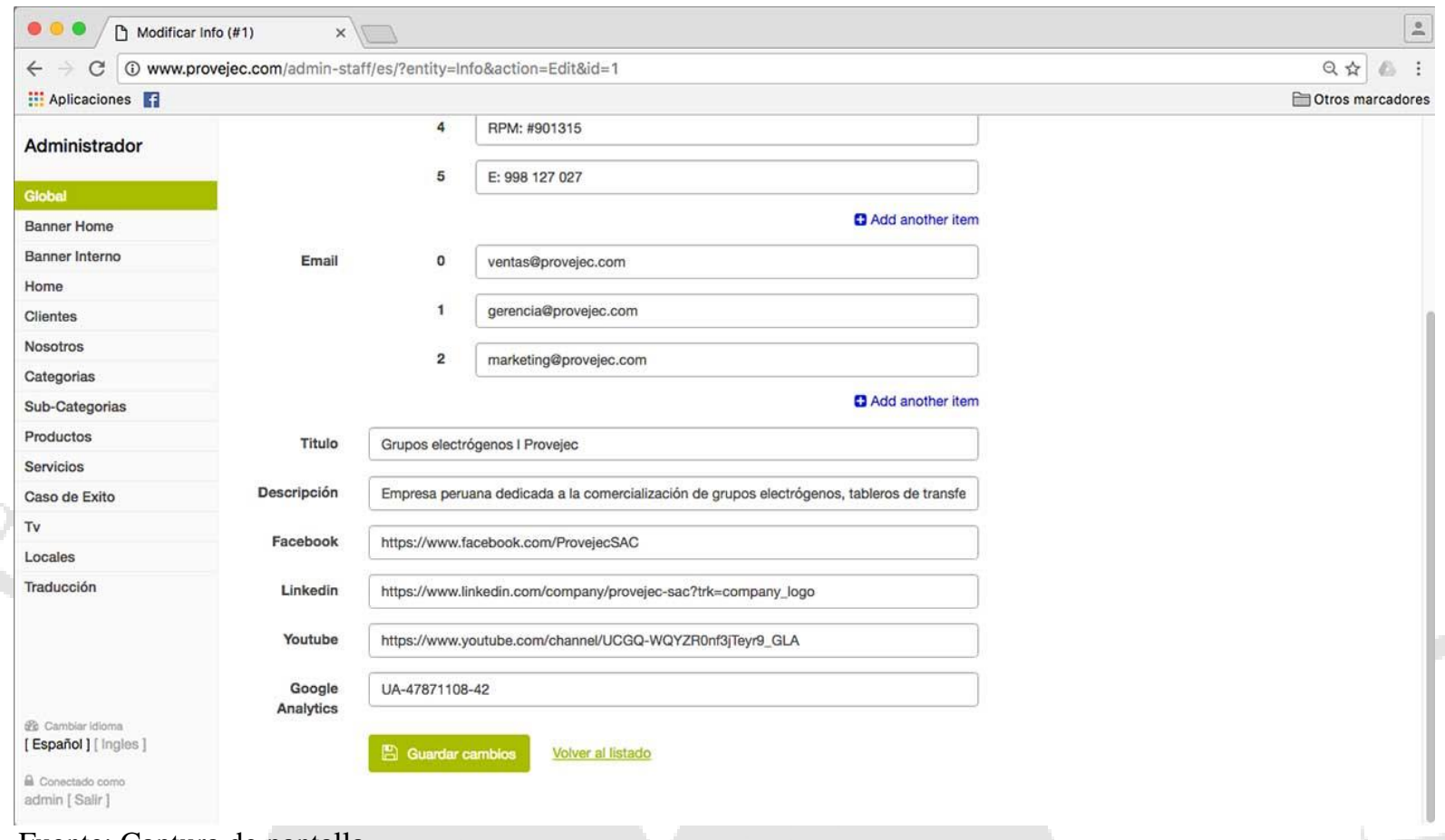

Fuente: Captura de pantalla.

En la sección de contacto se habilitó para cambiar los mails, los teléfonos y poder cambiar la ubicación de los locales, ya que en un futuro la empresa piensa vender el local de Ate y mudarse a otro distrito.

También se habilitó una sección para colocar el código que Google Analytics te brinda para enlazar al sitio web y tener la posibilidad de visualizar y analizar todas las estadísticas del sitio web.

\subsection{Accesibilidad y Responsive.}

El sitio web se diseñó para que se pueda apreciar en todos los exploradores sin alteraciones. También se implementó el sistema de web adaptativo (responsive) para que se pueda apreciar la interfaz del sitio web en cualquier tamaño de pantalla sin alterar la funcionalidad. 
Figura 3.16

Interfaz del sitio web en el explorador safari.

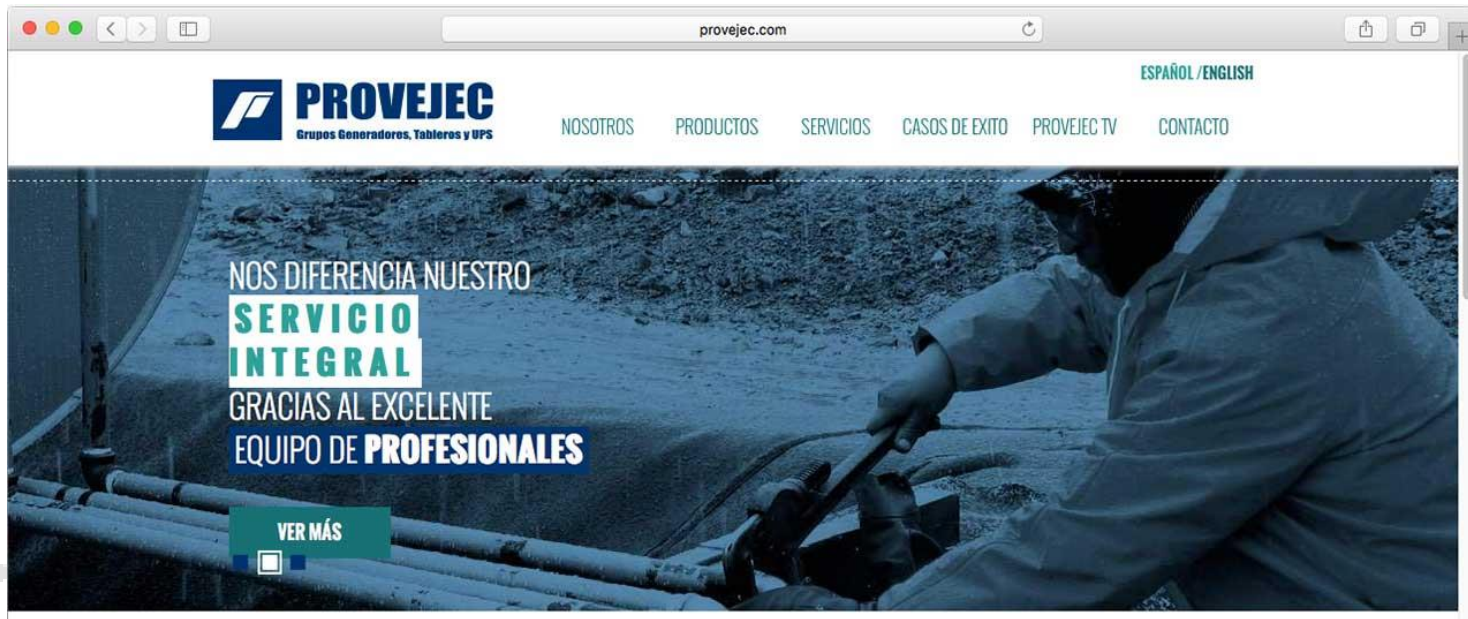

\section{- NUESTROS PRODUCTOS .}

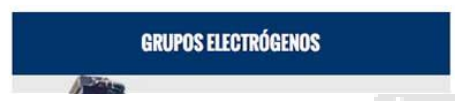

TABIEROSDE TRAYSFERENCIA

Fuente: captura de pantalla.

Figura 3.17

Interfaz del sitio web en una tablet.

\section{r PROVEJEE}

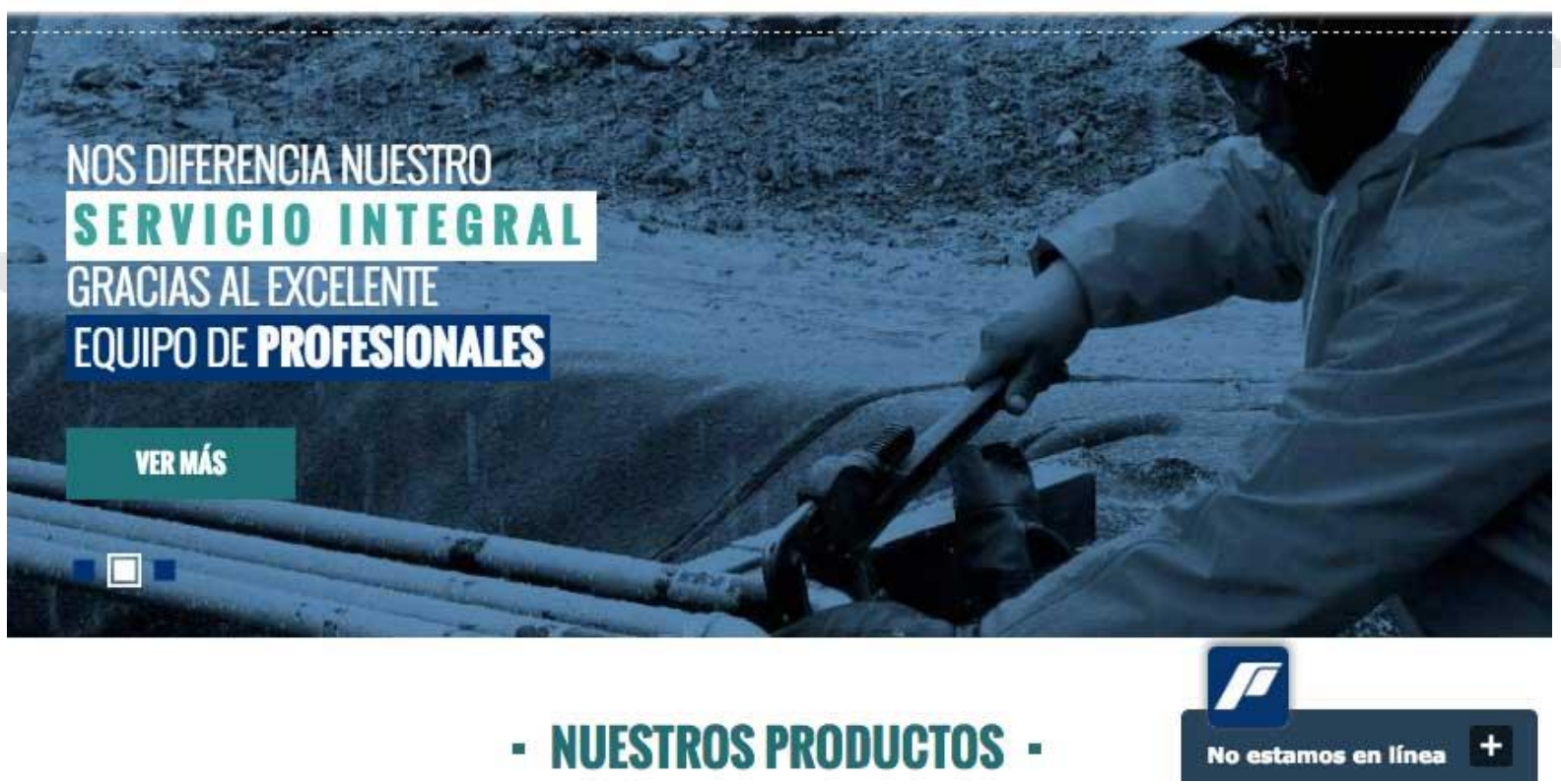

Fuente: captura de pantalla. 
Figura 3.18

Interfaz del sitio web en el explorador Mozila

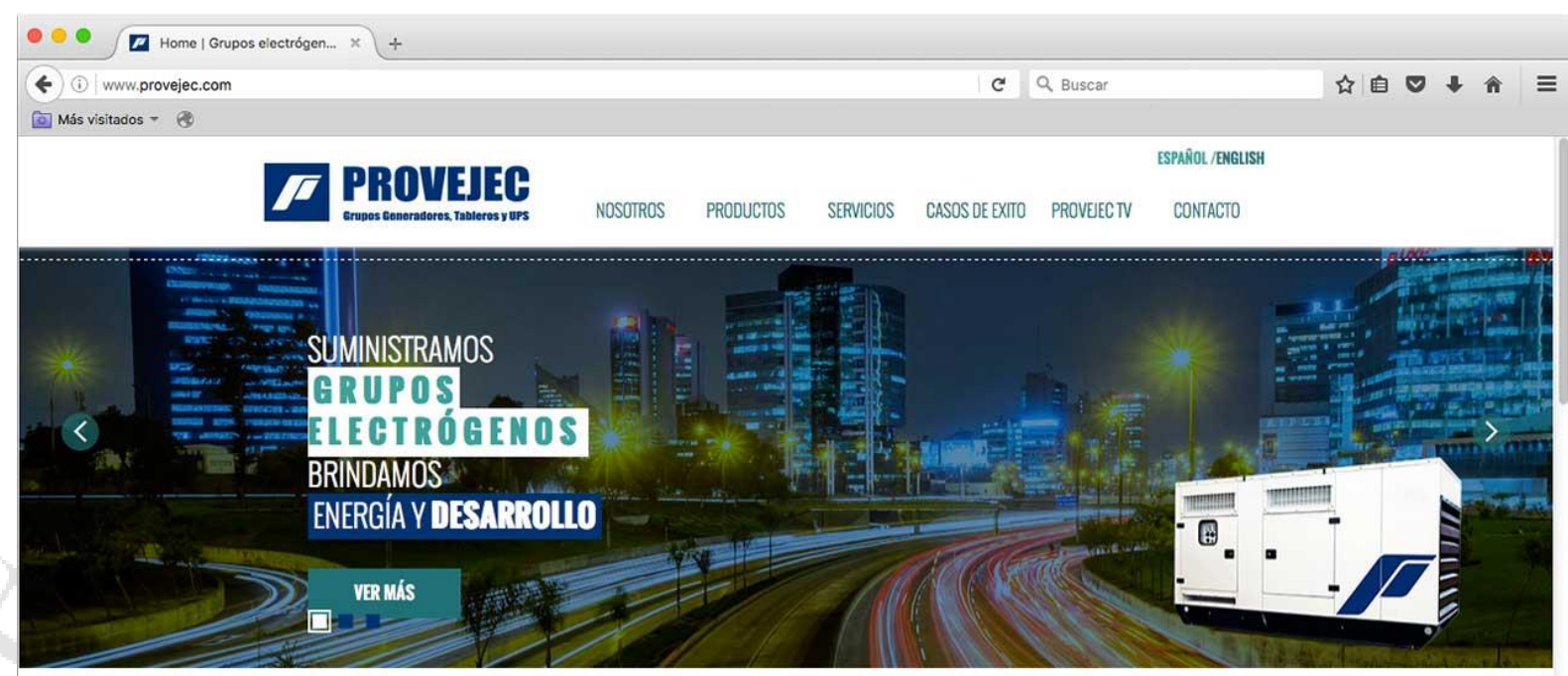

- NUESTROS PRODUCTOS -

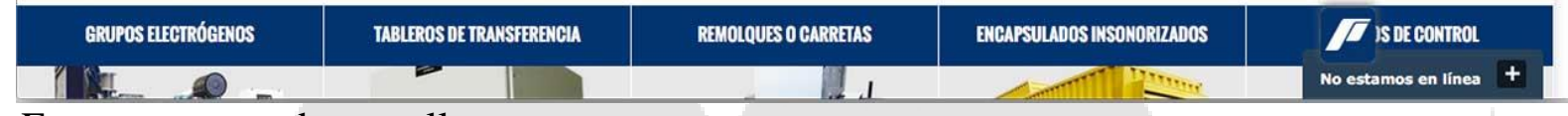

Fuente: captura de pantalla.

Figura 3.19

Interfaz del sitio web en un celular.

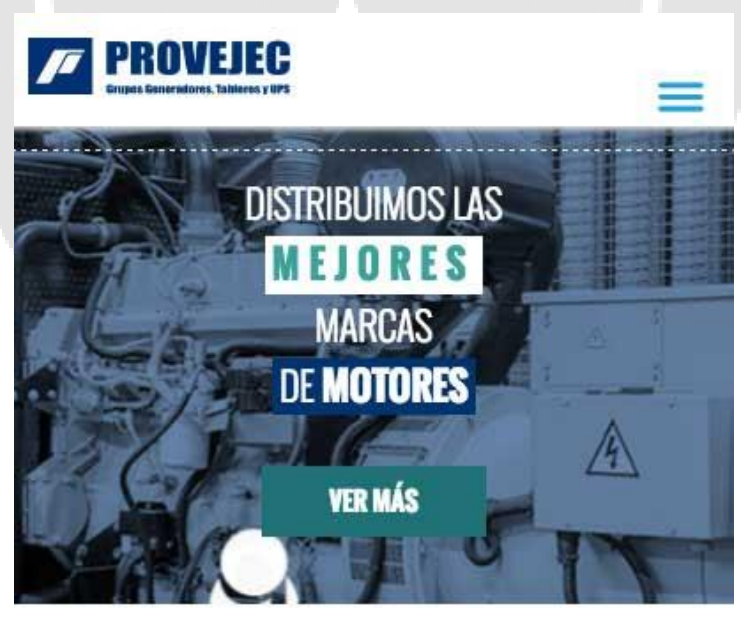

- NUESTROS PRODUCTOS -

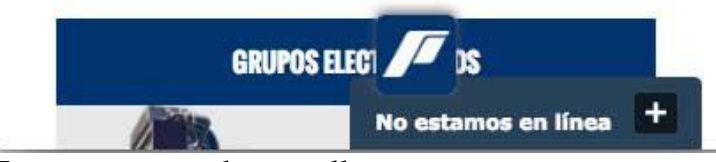

Fuente: captura de pantalla. 


\section{CAPÍTULO IV: ESTRATEGIA EN REDES SOCIALES}

\subsection{Estrategia en Facebook}

A continuación se mostrará la estrategia plasmada en la plataforma Facebook gestionada por el autor de este proyecto.

\subsubsection{Diseño y contenido}

El diseño de las imágenes del contenido se basó en los estándares de Facebook para que una imagen salga en buena calidad y resolución. En todas las imágenes de las publicaciones siempre se colocó una frase corta relacionada al tema de publicación y el logotipo de la empresa en la parte inferior izquierda, en el encabezado un texto descriptivo conciso junto a hashtags con las palabras clave del producto y un enlace direccionando a las distintas páginas web del sitio web dependiendo del tema tratado.

Tal como señala Moreno (2014) es importante definir las temáticas que se publicarán en las redes sociales y en los textos incluir las palabras clave de los productos o servicios de la empresa. Las publicaciones basadas en Facebook principalmente se basaron en las siguientes temáticas:

- Consejos para ahorrar energía en la casa o en la oficina.

- Casos de éxito de la empresa.

- Servicios de la empresa

- Contenido viral

- Mostrar productos de la empresa.

Para Moreno (2014) en las redes sociales se tiene que mostrar en lado humano de la empresa es por esto que se enfatizó en hacer publicaciones de consejos para ahorrar energía y seguridad eléctrica.

\subsubsection{Calendario de publicaciones y pauta.}


Tal como indica Moreno (2014) se creó un calendario de cada mes definiendo la temática, la frecuencia y el presupuesto destinado a cada publicación de Facebook. Las publicaciones fueron de una frecuencia de 2 veces por semana.

\section{Figura 4.1}

Planificación del contenido y pauta de Facebook.

Planificación del contenido y la frecuencia de publicación

PROVEJEC FACEBOOK SEPTIEMBRE 2015

\begin{tabular}{|c|c|c|c|c|c|c|c|}
\hline Noviembre & \multicolumn{2}{|c|}{ Lunes } & Martes Juércoles & Jueves & & \\
\hline Semana 1 & & & & & & & \\
\hline Semana 2 & consejo post 1 & & & brandin post2 & & & \\
\hline Semana 3 & & consejo post3 & & likes & & & \\
\hline Semana 4 & & brandin post 4 & & & consejo post5 & & \\
\hline Semana 5 & likes & & brandin post6 & & & & Sin Pauta \\
\hline
\end{tabular}

\begin{tabular}{|c|l|r|r|}
\hline DESCRIPCION & \multicolumn{2}{|l|}{ GASTO NUEVOS SOLES } & \\
\hline consejo post 1 & Consejo de ahorro de enegeía de laptop & 15 \\
\hline Brandin post 2 & Instalación de grupo electrógeno entel. & & \\
\hline consejo post3 & Consejo de ahorro de energía TV & 15 \\
\hline likes1 & Likes & 15 \\
\hline brandin post 4 & Publicidad estadio & 15 \\
\hline consejo post5 & Consejo de ahorro de energía (regrigeradora). & & \\
\hline likes2 & likes & 15 \\
\hline brandin post6 & Llegamos a todo el Perú. & 15 \\
\hline & & 15 \\
\hline
\end{tabular}

Fuente: elaboración propia.

\subsubsection{Contenido Viral}

En la estrategia de contenidos en Facebook se hizo publicaciones que se puedan relacionar a las tendencias que se viralizaban en Facebook. Para Somalo (2011) para que un contenido se viralice tiene que ser creativo y sorprender al usuario. Un caso en particular fue una publicación que hacía referencia a los constantes apagones en el estadio del equipo Universitario de deportes, la cual tuvo un alcance masivo incluso apareciendo como noticia en la versión digital de los principales diarios. 
Figura 4.2

Publicación de contenido viral en Facebook.

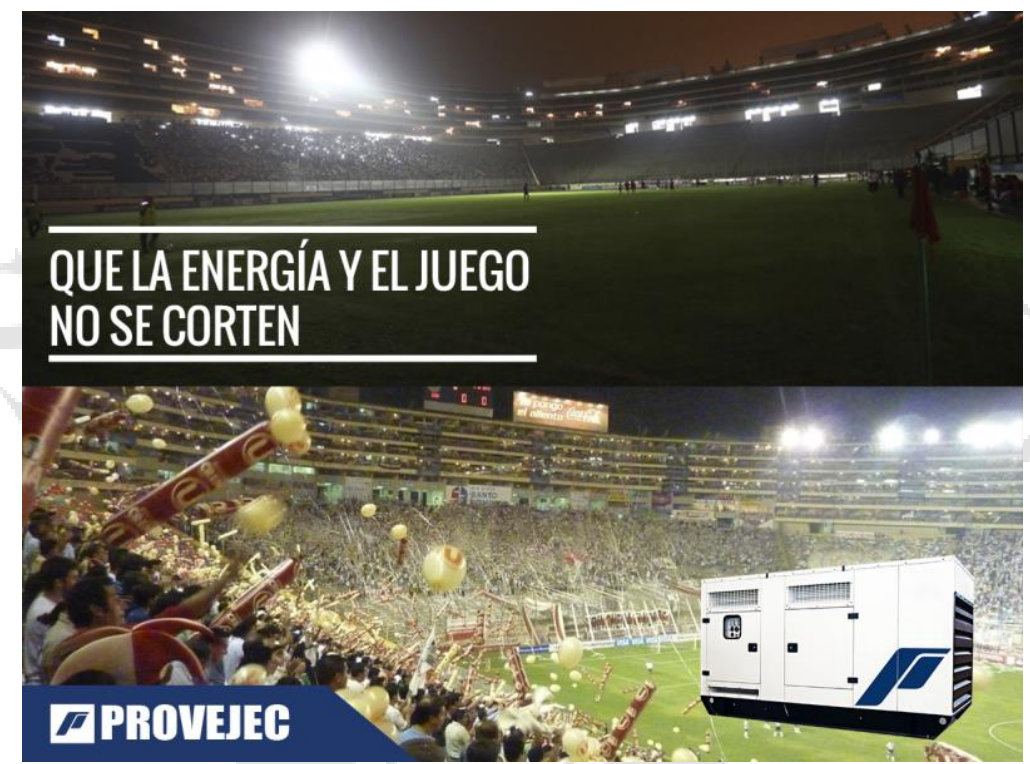

Fuente: captura de pantalla.

Figura 4.3

Noticia en el portal la 10.
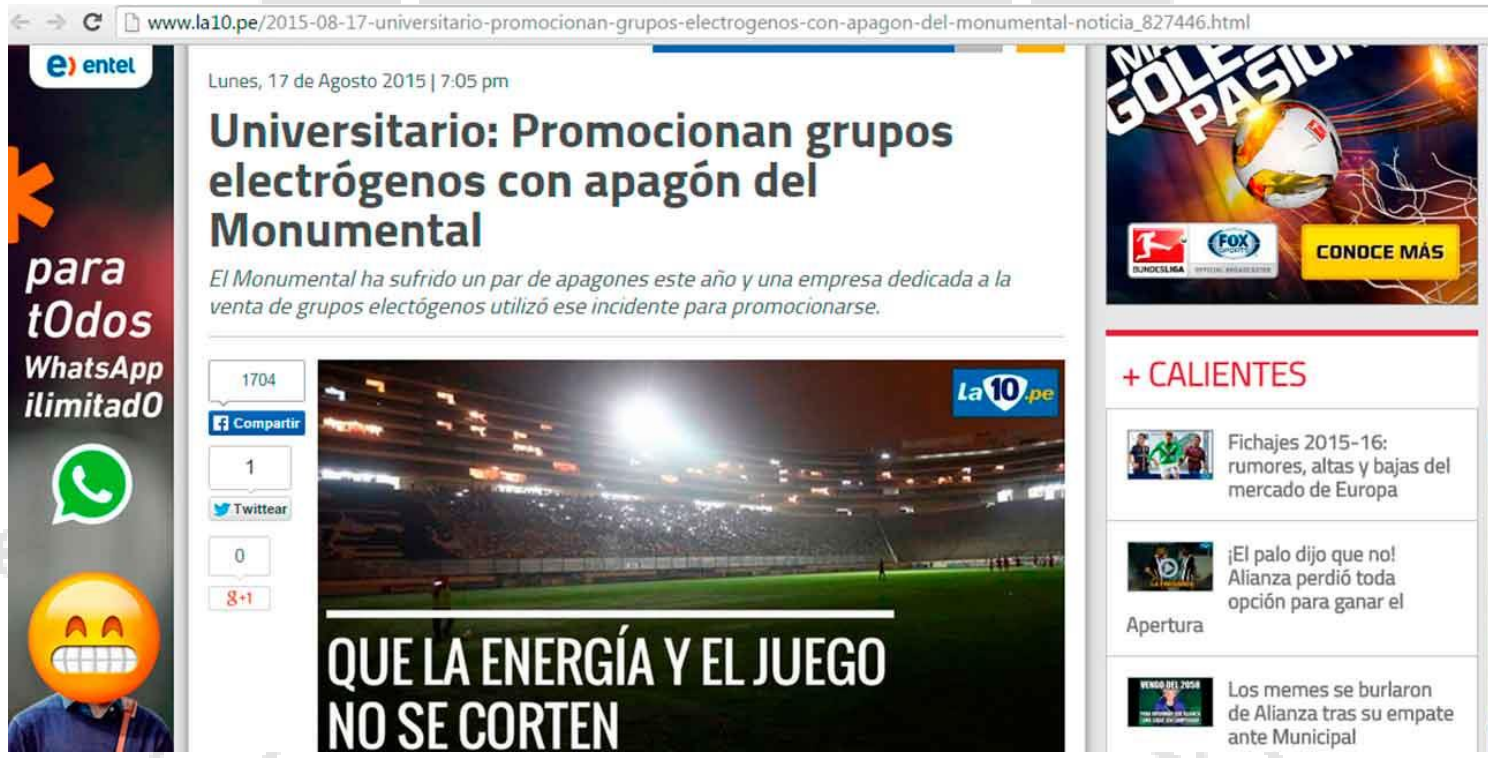

+ CALIENTES

find 1 Fichajes 2015-16:
rumores, altas y bajas del mercado de Europa

El palo dijo que no! Alianza perdió toda Apertura pción para ganar el

Fuente: captura de pantalla del portal la 10 Octubre 2015. 
Figura 4.4

Noticia en el portal de RPP.

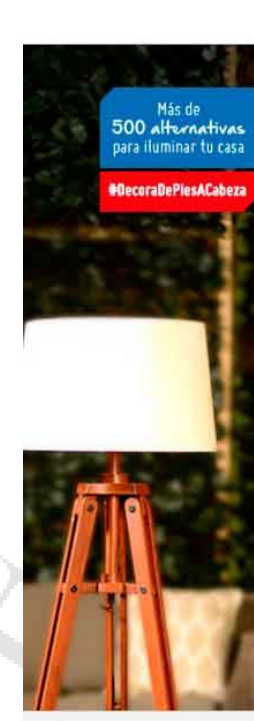

$$
\text { RPP NOTICas }
$$

(6) ENVIVO: LOSCHISIOSOS

- resumendelahora f y o i $Q \mid \equiv$ Universitario: Empresa utiliza imagen del apagón para promocionar productos

Imagen de uno de los muchos apagones que sufrió el Monumental fue utilizada por una empresa dedicada a la venta de grupos electrōgenos.
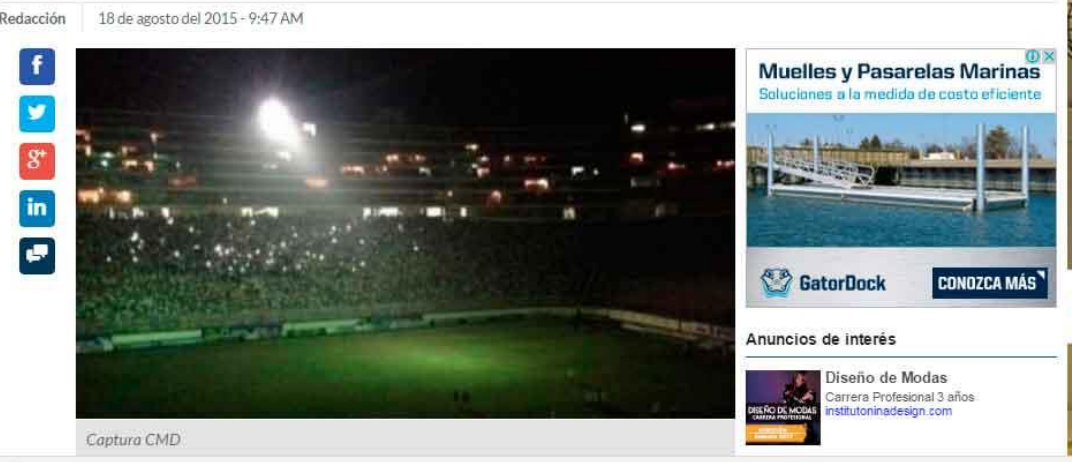

E 14690961_101543...jpg ^

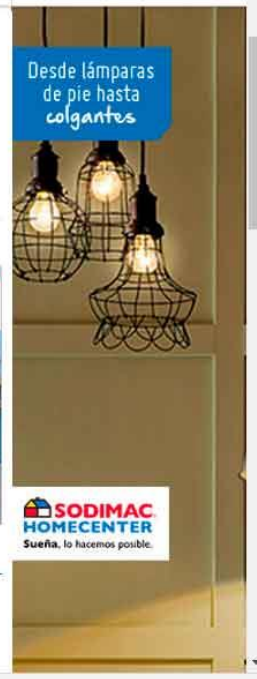

Mostrar todo $\times$

Fuente: captura de pantalla del portal RPP Octubre 2015,

Figura 4.5

Noticia en el portal Depor.

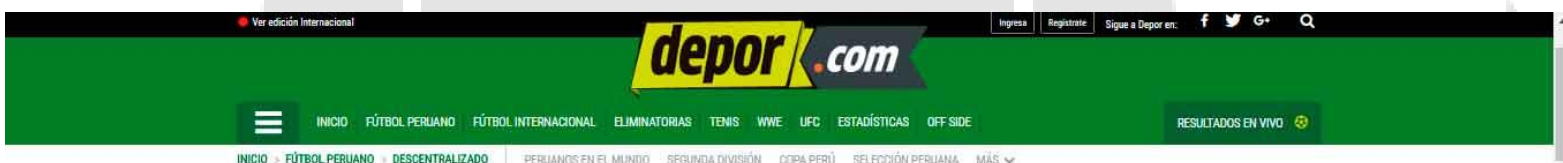

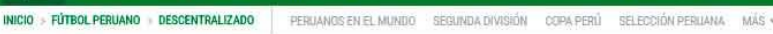

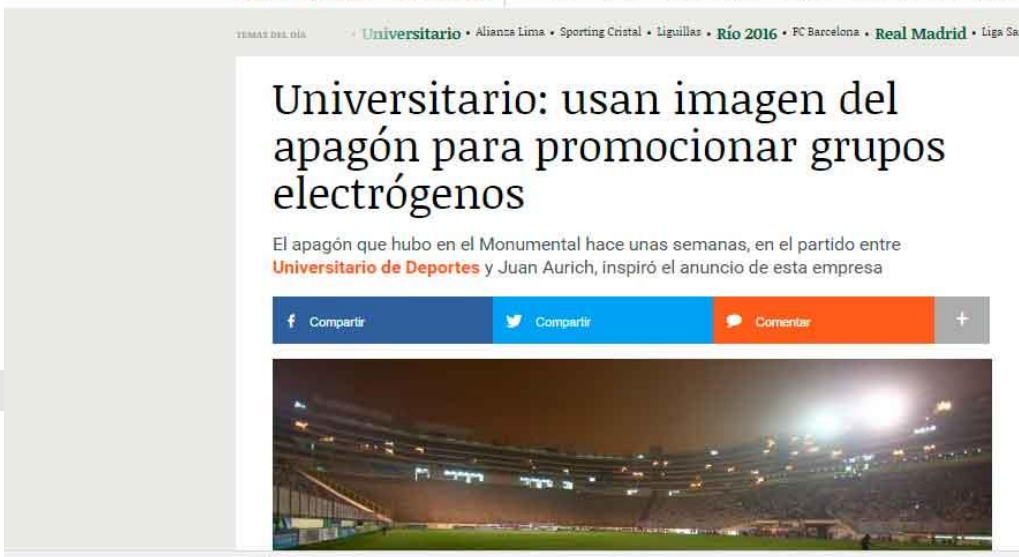

E. 14690961 _101543....jpg

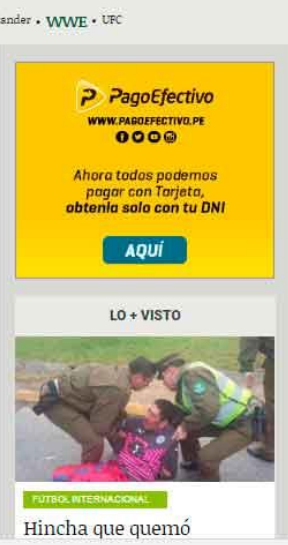

Fuente: captura de pantalla Depor Octubre 2015. 


\subsubsection{Segmentación y pauta.}

Al tener un presupuesto sólo de 100 dólares se asignó la mitad para Facebook que aproximadamente eran 150 soles por mes. De las cuales se puso pauta a dos publicaciones semanales con una inversión entre 15 y 20 soles cada una. Posteriormente se aumentó la pauta por cada publicación y sólo se invirtió en las publicaciones que se consideraron más relevantes para obtener un mayor alcance y por ende un mayor porcentaje de conversión.

Se consideró estos parámetros para la mayoría de las publicaciones:

\section{Tabla 4.1}

Segmentación de publicaciones de Facebook.

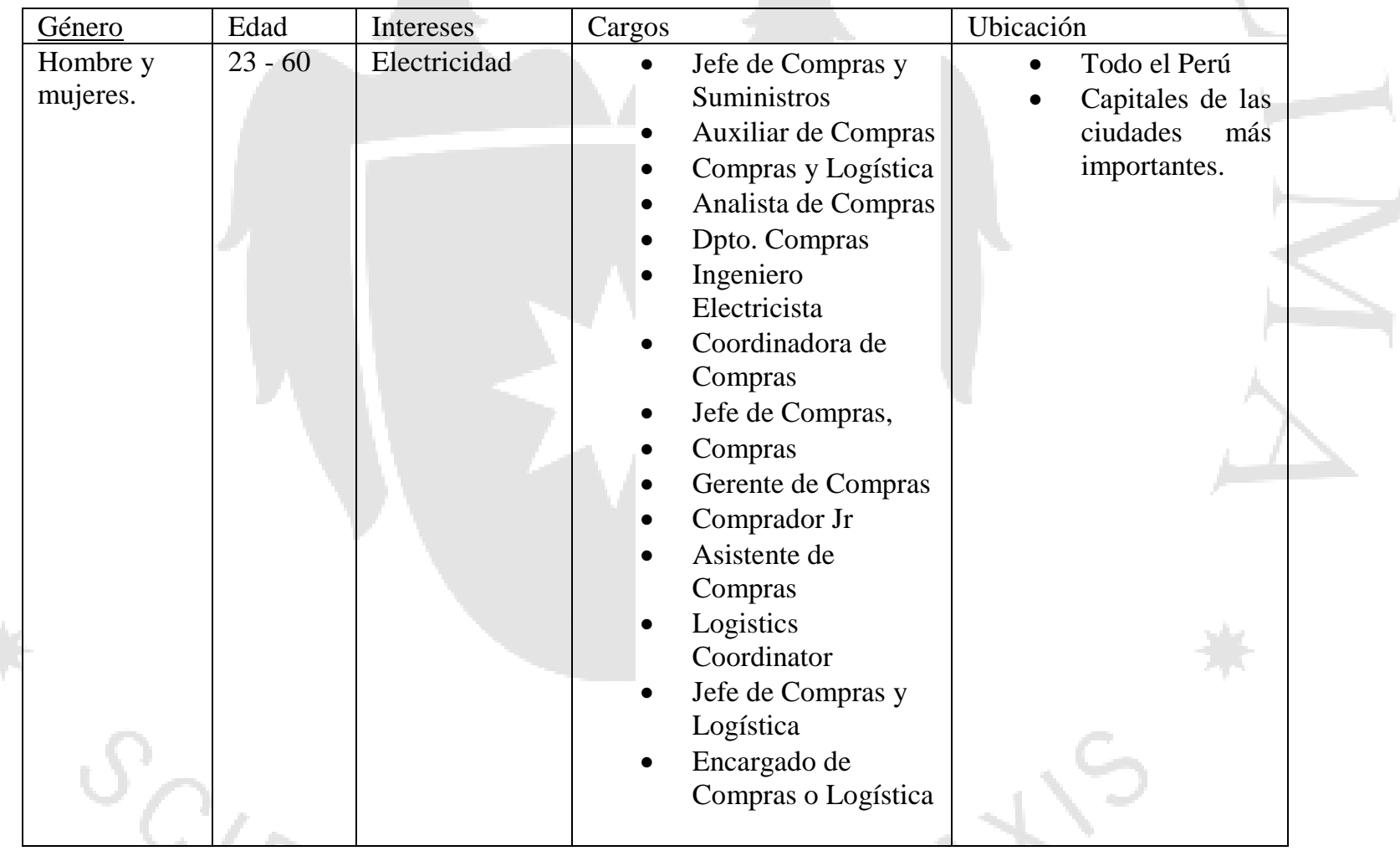

\subsection{Estrategias en LinkedIn.}

Para Kerpen (2012) tener presencia en LinkedIn es fundamental porque hay mucho más variedad de perfiles profesionales incluso están los altos directivos que no podrían estar en Facebook. Es por esto que se decidió tener presencia en esta red social. 


\subsubsection{Diseño y contenido}

El diseño para LinkedIn se basó en los estándares para que las imágenes salgan de buena calidad y resolución. También en todas las publicaciones se colocó una frase dentro de la imagen que esté relacionada al tema publicado y un texto descriptivo en el encabezado de la publicación y los enlaces respectivos al sitio web.

El contenido publicado en LinkedIn se basó principalmente en mostrar el servicio integral de la empresa y los productos de la empresa. También se publicaron noticias relacionadas al rubro de energía eléctrica. Las temáticas publicadas fueron:

- Casos de éxito de la empresa.

- Servicios de la empresa

- Branding de la marca

- Noticias relacionadas al rubro.

\subsubsection{Calendario de publicaciones y pauta}

Al igual que Facebook se creó un calendario de publicación indicando la temática de la publicación, la frecuencia y el presupuesto destinado a cada publicación.

Figura 4.6

Planificación del contenido y pauta de LinkedIn.

\begin{tabular}{|c|c|c|c|c|c|c|c|}
\hline \multicolumn{8}{|c|}{ Planificación del contenido y la frecuencia de publicación } \\
\hline \multicolumn{3}{|c|}{ PROVEJEC LINKEDIN SEPTIEMBRE } & \multirow{3}{*}{ Miércoles } & \multirow{3}{*}{ Jueves } & \multirow{3}{*}{ Viernes } & \multirow{3}{*}{ Sábado } & \\
\hline Noviembre & Lunes & Martes & & & & & Domingo \\
\hline Semana 1 & & & & & & & \\
\hline Semana 2 & informetivo & & & brandin & & & \\
\hline Semana 3 & & intermatives & brandin & & & & \\
\hline Semana 4 & & branding & & & informativg & & \\
\hline Semana 5 & tranding & & informative & & & & \\
\hline
\end{tabular}

\begin{tabular}{|c|l|r|r|}
\hline DESCRIPCION & & \\
\hline intarmativo & Noticia del rubro electrico Paque eloico de la brea producira 30 megatios & & \\
\hline Post1 & video de paralelismo de grupos electrógenos & & \\
\hline post 2 & Video funcionamiento grupos electrógeno & 10 \\
\hline informativa & Noticia de presupuesto de grupos electrógenos & 10 \\
\hline post 3 & Generadores hibridos & 10 \\
\hline post4 & Publicación entel & & \\
\hline post 5 & & 12 \\
\hline post 6 & & & \\
\hline post 7 & & & \\
\hline
\end{tabular}

Fuente: Elaboración propia. 


\subsubsection{Segmentación y pauta}

El presupuesto destinado para LinkedIn fue de 50 dólares mensuales que se dividió en 12 dólares para una publicación por semana. Posteriormente se aumentó la pauta a las publicaciones más relevantes para obtener un mayor alcance y conversión.

La segmentación de los anuncios tuvo estos parámetros:

Tabla 4.2

Segmentación publicaciones LinkedIn.

\begin{tabular}{|c|c|c|c|c|}
\hline Género & Edad & Ubicación & $\begin{array}{l}\text { Sector } \\
\text { empresarial }\end{array}$ & Cargos de los usuarios. \\
\hline $\begin{array}{l}\text { Hombre y } \\
\text { mujeres }\end{array}$ & $21-55$ & Lima & $\begin{array}{l}\text { Todos los } \\
\text { sectores }\end{array}$ & $\begin{array}{ll}\text { - } & \text { Jefe de Compras } \\
& \text { y Suministros } \\
\text { - } & \text { Auxiliar de } \\
& \text { Compras } \\
\text { - } & \text { Compras y } \\
& \text { Logística } \\
\text { - } & \text { Analista de } \\
& \text { Compras } \\
\text { - } & \text { Dpto. Compras } \\
\text { - } & \text { Ingeniero } \\
& \text { Electricista } \\
\text { - } & \text { Coordinadora de } \\
& \text { Compras } \\
\text { - } & \text { Jefe de Compras, } \\
\text { - } & \text { Compras } \\
\text { - } & \text { Gerente de } \\
& \text { Compras } \\
\text { - } & \text { Comprador Jr } \\
\text { - } & \text { Asistente de } \\
& \text { Compras } \\
\text { - } & \text { Logistics } \\
& \text { Coordinator } \\
\text { - } & \text { Jefe de Compras } \\
\text { - } & \text { E Logística } \\
& \text { Encargado de } \\
& \text { Logística } \\
& \\
\end{array}$ \\
\hline
\end{tabular}

Fuente: elaboración propia. 


\section{CAPÍTULO V: ESTRATEGIA SEO Y SEM}

\subsection{Estrategia SEO}

Lo primero que se planteó para la estrategia SEO fue definir las palabras clave que normalmente los clientes colocan en la barra del buscador para buscar los productos de la empresa. Se planteó un primer grupo principal de palabras clave a trabajar para aumentar el ranking en los resultados de búsqueda. Las palabras clave elegidas fueron:

- grupos electrógenos

- venta de grupos electrógeno

- grupos electrógenos Perú

El segundo grupo de palabras clave está relacionado con el resto de productos:

- encapsulados insonorizados

- deep sea electronics

- deep sea electronics peru

- tanques de combustible

- carretas para grupos electrógenos

- tableros de transferencia automática

\subsubsection{Estrategias On-page.}

La primera estrategia fue la correcta colocación de las diversas meta etiquetas en todo el sitio web. Una de las más importantes fue la descripción principal del sitio web, se colocó un texto descriptivo general de la empresa con las palabras de los principales productos. Se colocó también en la URL de cada página de los productos la palabra clave correspondiente para ayudar a que el motor de búsqueda reconozca el tema de cada página web. 
Como afirma Fleischner (2013) la experiencia del usuario es importante para escalar posiciones en el ranking de las búsquedas. Como se había mencionado en el primer capítulo se diseñó el sitio web para garantizar una experiencia del usuario óptima.

\section{Figura 5.1}

Urls en el sitio web de provejec.

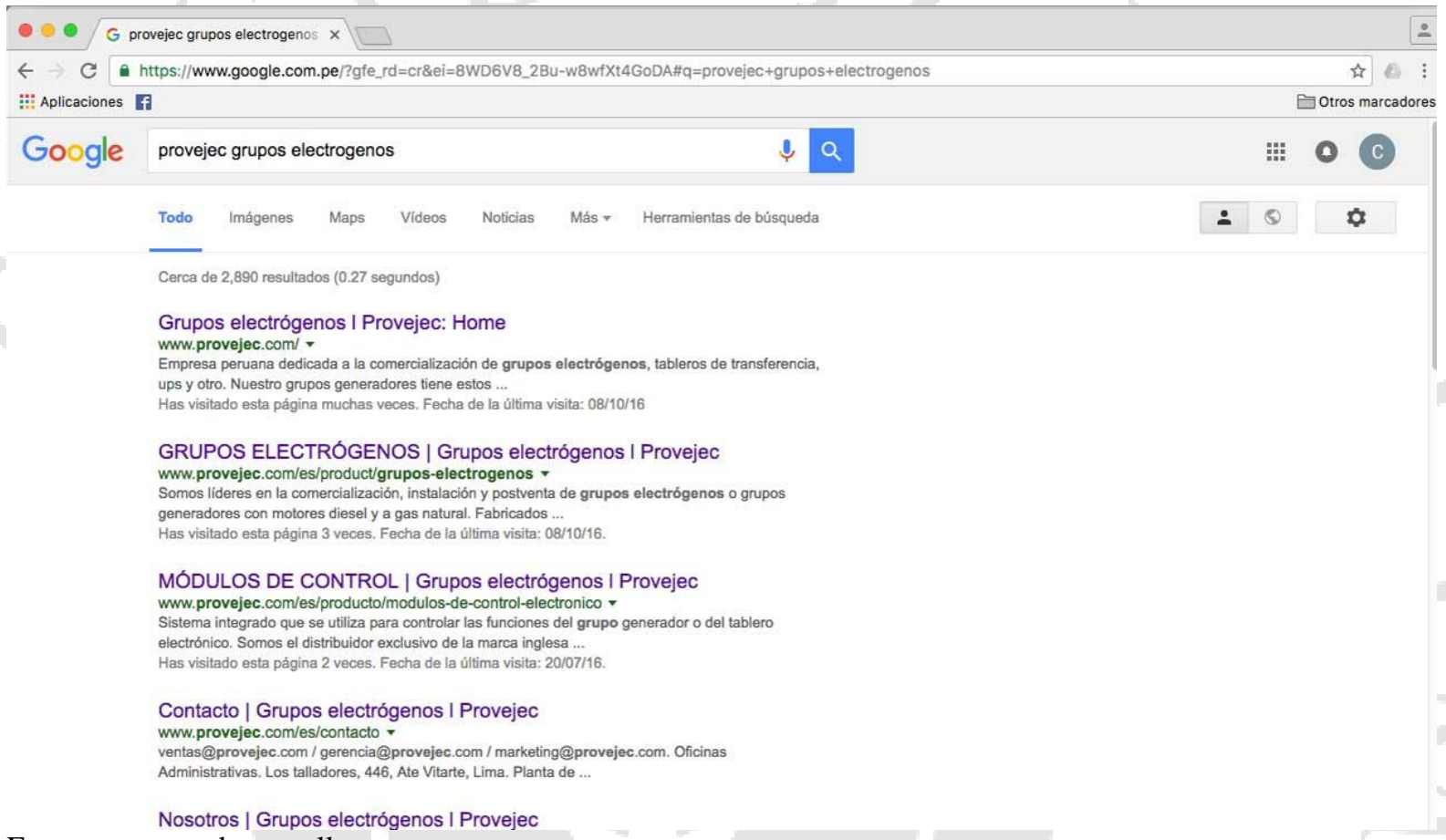

Fuente: captura de pantalla.

Ya que la velocidad de descarga es importante para los motores de búsqueda, se optimizaron las imágenes para que la descarga sea rápida. Se verificó esto con la herramienta de Google Pagespeed Tools. 
Figura 5.2

Velocidad de descarga del sitio web de Provejec.

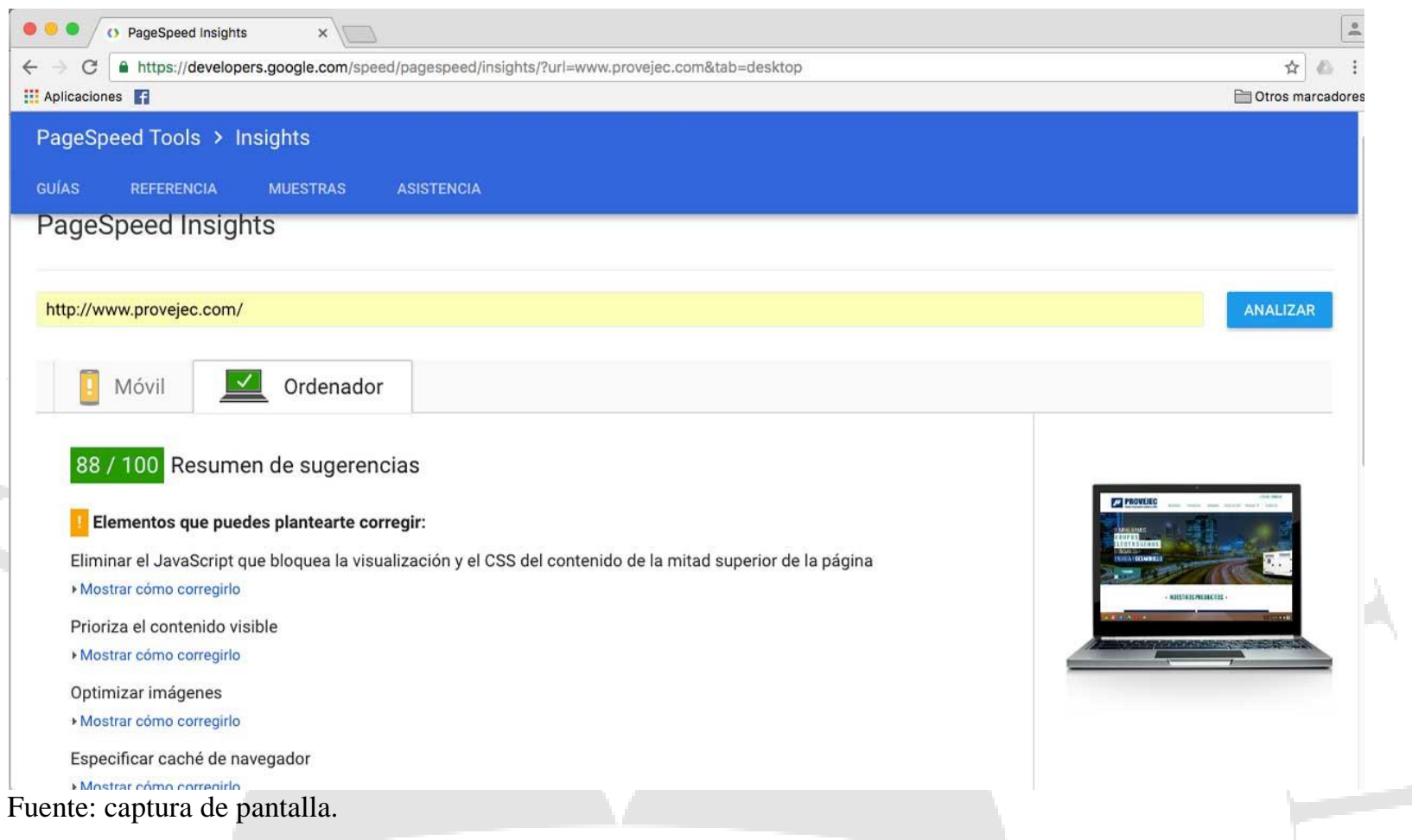

Tal como los afirma Fleischner (2013) una de las estrategias más importantes on-page es la creación de contenido audiovisual. Se creó un canal de Youtube el cual está enlazado a la sección PROVEJEC TV y se colgaron 4 videos relacionados al rubro de la empresa. Esta acción fue de suma relevancia para Provejec, ya que los competidores medianos no contaban con este recurso. Los videos, como se había mencionado anteriormente, fueron producidos por el autor de este proyecto. Los 4 videos tuvieron un total de 1208 vistas orgánicas. La temática de los videos colgados fueron:

- Eventos internos de la empresa.

- Servicios realizados.

- Información del funcionamiento de los equipos que comercializa Provejec. 
Figura 5.3

Video sobre campeonato de fútbol día del trabajo.

CAMPEONATO DE FÚTBOL
Por el día del trabajo
El día del trabajo la familia de
PROVEJEC celebró organizando un
campeonato de fútbol 6 entre las
áreas de la empresa. Felicitamos al
equipo de Mecánica 1 por haber
ganado el campeonato.
COMPARTE:
f :

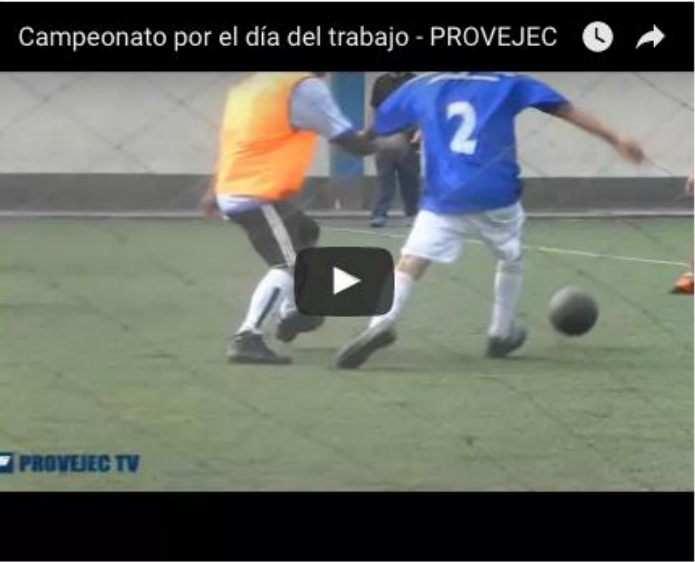

Fuente: Captura de pantalla.

Figura 5.4

Video sobre el funcionamiento de un grupo electrógeno.

PROVEJEC - ¿Como funciona un grupo electrógeno?

Brindamos Energía, Brindamos Desarrollo

< Este video muestra como funciona un grupo electrógeno ante la perdida de la red comercial.

\section{COMPARTE:}
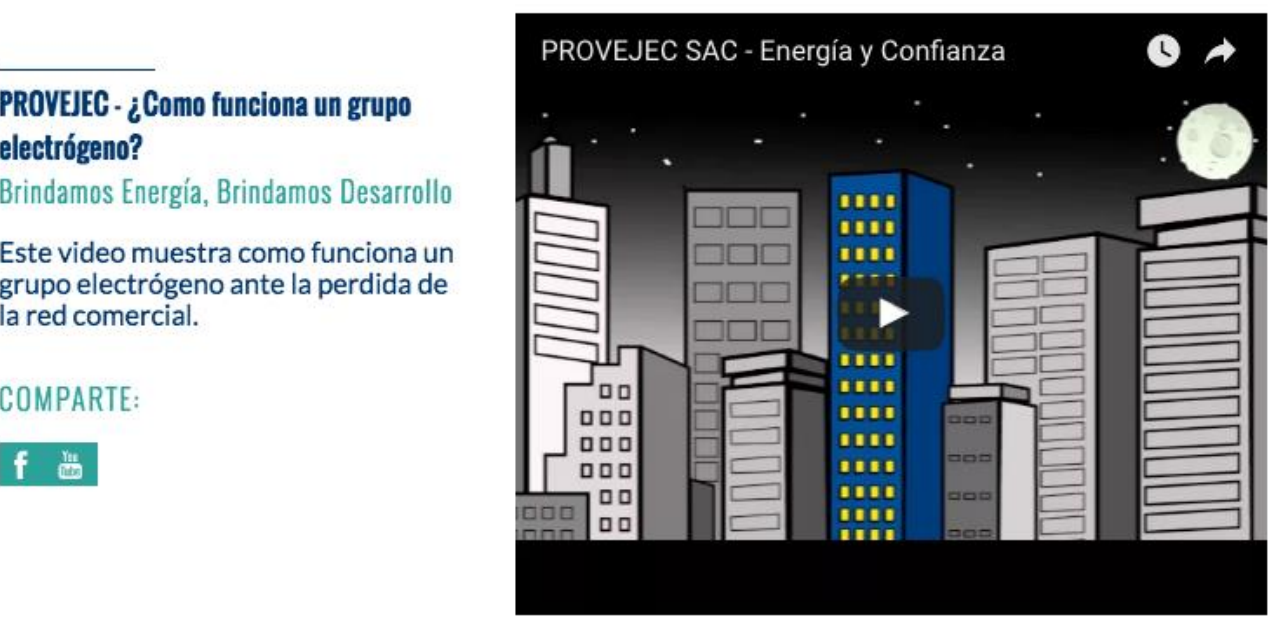

Fuente: Captura de pantalla.

\subsubsection{Estrategias OFF page.}

Se utilizó la estrategia de "link-building" registrando el sitio web de Provejec en directorios web de empresas de Perú para aumentar la relevancia de la página. En el sitio web de DEEP SEA ELECTRONICS se colocó el enlace del sitio web de Provejec confirmado la distribución oficial de sus productos en el Perú. Esto hizo que el sitio web 
de Provejec aparezca primero en los resultado de búsqueda al colocar la palabra clave “deep sea electronics Perú" en el cuadro de búsqueda.

\section{Figura 5.5}

Resultado de búsqueda de la palabra clave "deep sea electronics peru"

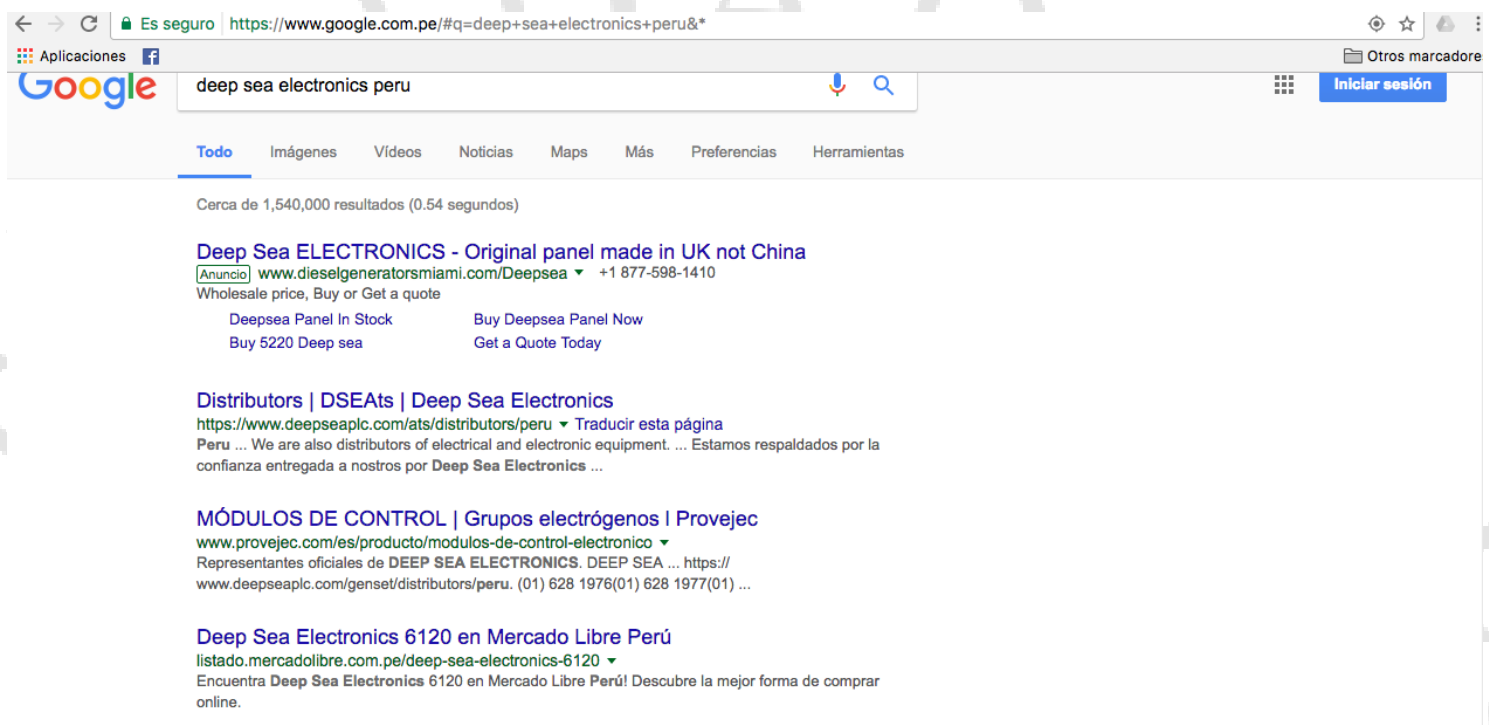

Fuente: Captura de pantalla.

Como señala García el contenido creado en las redes sociales también influye directamente en el SEO. Se realizó un plan de contenidos en Facebook y Linkedin posteando con frecuencia contenido relevante del rubro y de la empresa. Las publicaciones posteadas siempre con las palabras claves del producto principal de la empresa junto con un link que direccionaba al sitio web para reforzar la estrategia "linkbuilding".

\subsection{Estrategia SEM}

La agencia administradora del hosting del sitio web se encargó de administrar la campaña de Google Adwords. Se brindó una lista de palabras clave para que activaran los anuncios de Adwords. La lista de palabras clave seleccionadas son: 


\section{Tabla 5.1}

Palabras clave para la campaña de anuncios pagados.

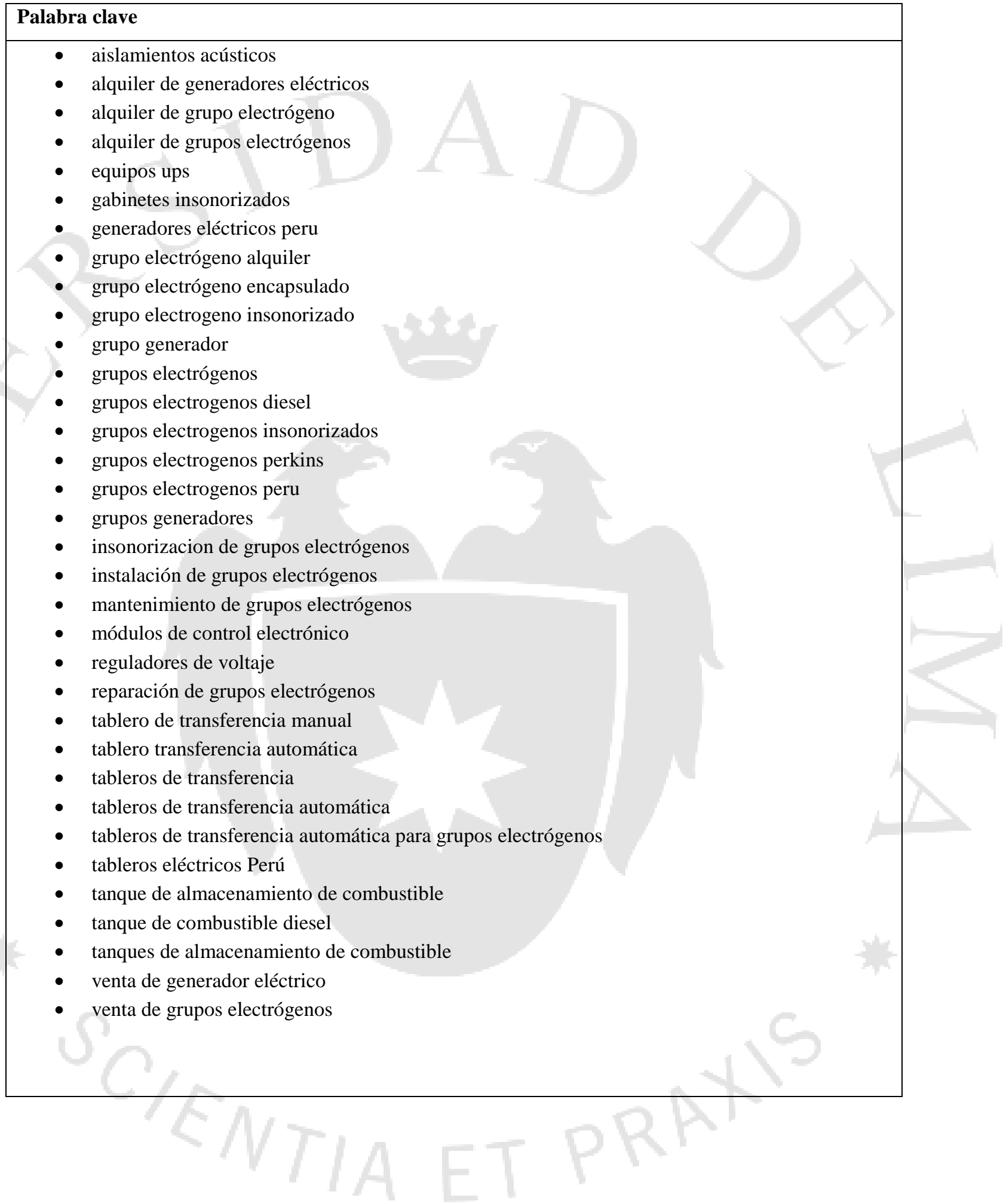


Figura 5.6

Anuncio de Google Adword de Provejec.

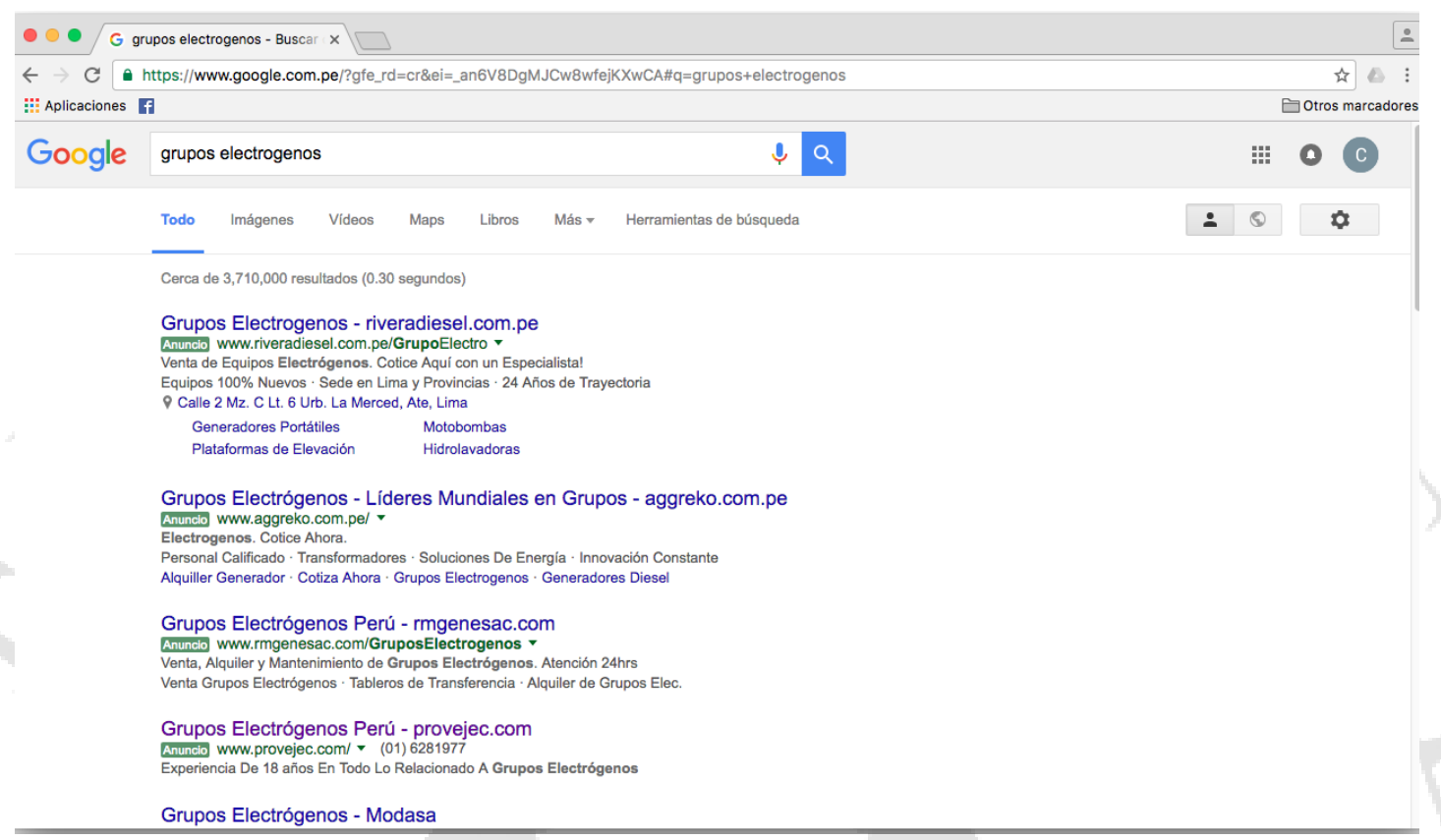

Fuente: captura de pantalla.

La agencia mensualmente envía reportes con el rendimiento de las palabras clave y los anuncios para analizar las estadísticas y evaluar realizar cambios para optimizar la campaña. 


\section{CAPÍTULO VI: VALIDACIÓN DE LAS ACCIONES REALIZADAS EN BASE A LOS OBJETIVOS PLANTEADOS}

En este capítulo se mostrará los resultados del proyecto en base a los objetivos planteados.

\subsection{Validación de las redes sociales}

\subsubsection{Facebook}

A continuación se presentará las publicaciones más importantes de cada eje temático del plan de contenidos en Facebook.

Eje temático: Promoción de productos

Figura 6.1

Publicación promoción de productos

Provejec

Publicado por Carios Salazar Claudet 71-28 de septiembre a fas 14:28 - o

Si el cliente lo requiere suministramos \#gruposelectrógenos con carretas para facilitar la movilización de estos.

Para mas información: http://goo.gl/k2EvsD

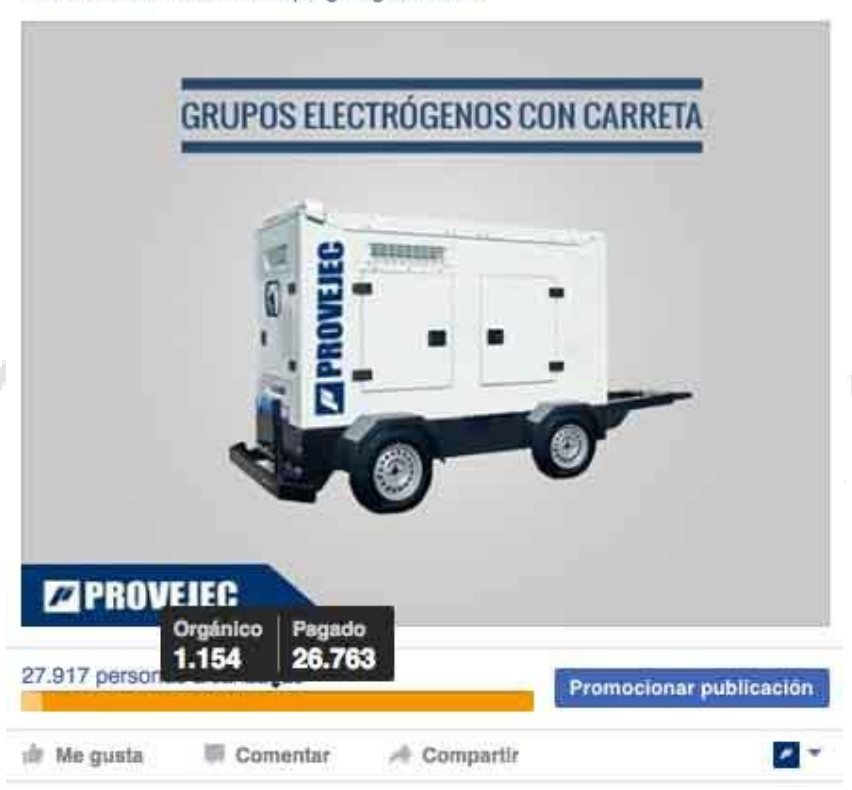


Fuente: captura de pantalla de Facebook.

Figura 6.2

Comentarios de la publicación de Facebook.

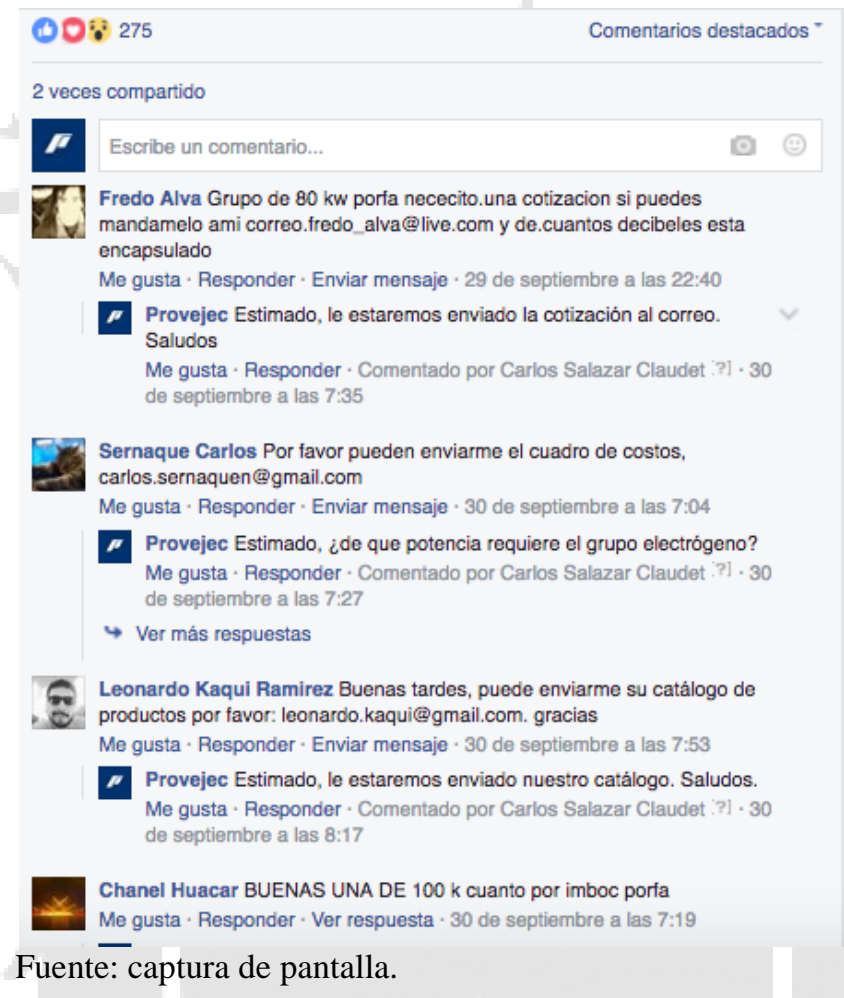

Esta publicación se mostró un grupo electrógeno con carreta móvil ya que la mayoría de empresas de la competencia sólo brindan el grupo electrógeno sin accesorios. En este caso la inversión fue de 150 soles, ya que fue una publicación para obtener mayor tráfico a la web y por ende mayor número de conversiones. A continuación mostraré las estadísticas más importantes de esta publicación.

Tabla 6.1

Estadísticas de la publicación de promoción de productos.

\begin{tabular}{|c|c|c|c|c|c|c|}
\hline $\begin{array}{c}\text { Alcance } \\
\text { total }\end{array}$ & Reacciones & $\begin{array}{l}\text { Veces que } \\
\text { se compartió }\end{array}$ & $\begin{array}{c}\text { Clicks } \\
\text { en } \\
\text { enlace }\end{array}$ & $\begin{array}{l}\text { Otros } \\
\text { clicks }\end{array}$ & $\begin{array}{l}\text { Comentarios } \\
\text { preguntando } \\
\text { por cotización }\end{array}$ & Inbox \\
\hline 27,917 & 306 & 10 & 33 & 94 & 12 & 3 \\
\hline
\end{tabular}


El día que se programó la pauta de esta publicación se logró que Facebook sea el primer canal de adquisición al sitio web.

\section{Figura 6.3}

Adquisición de la publicación.

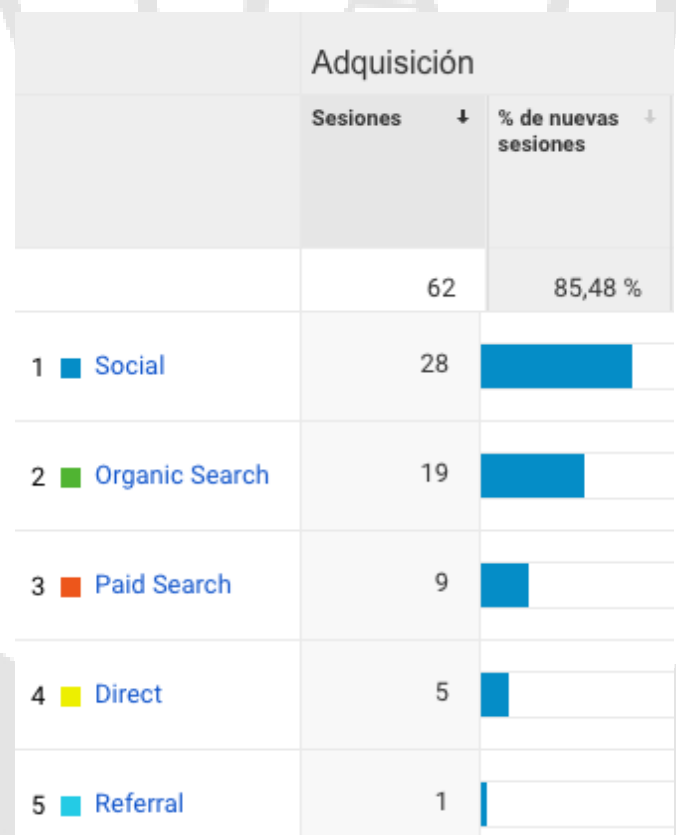

Fuente: Captura de pantalla. 
Eje temáitco: Consejos ahorro de energía.

Figura 6.4

Publicación de consejo ahorro de energía.

$\boldsymbol{\mu}$

Provejec con Rut Vilela

Publicado par Provejec Sac [?] - 4 de septiembre de $2015 \cdot 6$

Aportemos nuestro granito de arena ahorrando energia para cuidar el planeta: \#ahorrodeenergia \#cuidandoalplaneta

www.provejec.com

Grupos electrógenos.

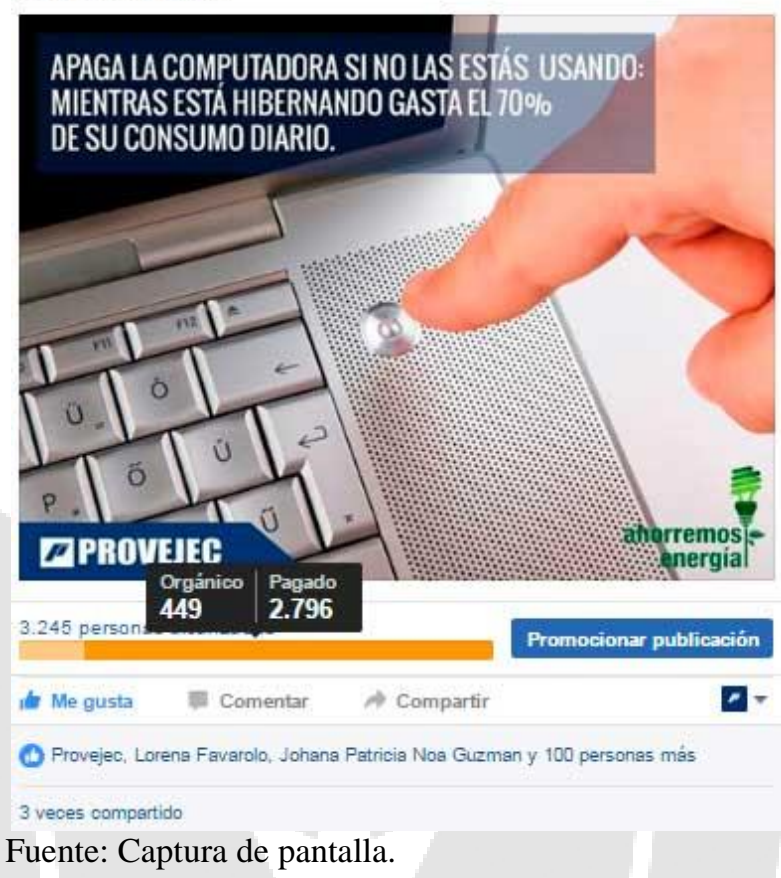

Es esta publicación y en todas las de este eje temático se mostró consejos cotidianos para ahorrar energía que cualquiera pueda realizar con facilidad. En este caso la publicación fue de 20 soles. Estas son las estadísticas de esta publicación:

Tabla 6.2

Estadísticas de la publicación de consejo de ahorro de energía.

\begin{tabular}{|c|c|c|c|c|}
\hline $\begin{array}{c}\text { Alcance } \\
\text { total }\end{array}$ & Reacciones & $\begin{array}{c}\text { Veces que } \\
\text { se compartió }\end{array}$ & $\begin{array}{c}\text { Clicks } \\
\text { en } \\
\text { enlace }\end{array}$ & $\begin{array}{c}\text { Otros } \\
\text { clicks }\end{array}$ \\
\hline 3,245 & 120 & 7 & 0 & 94 \\
\hline
\end{tabular}


Eje temático: Casos de éxito

Figura 6.5

Publicación de caso de éxito

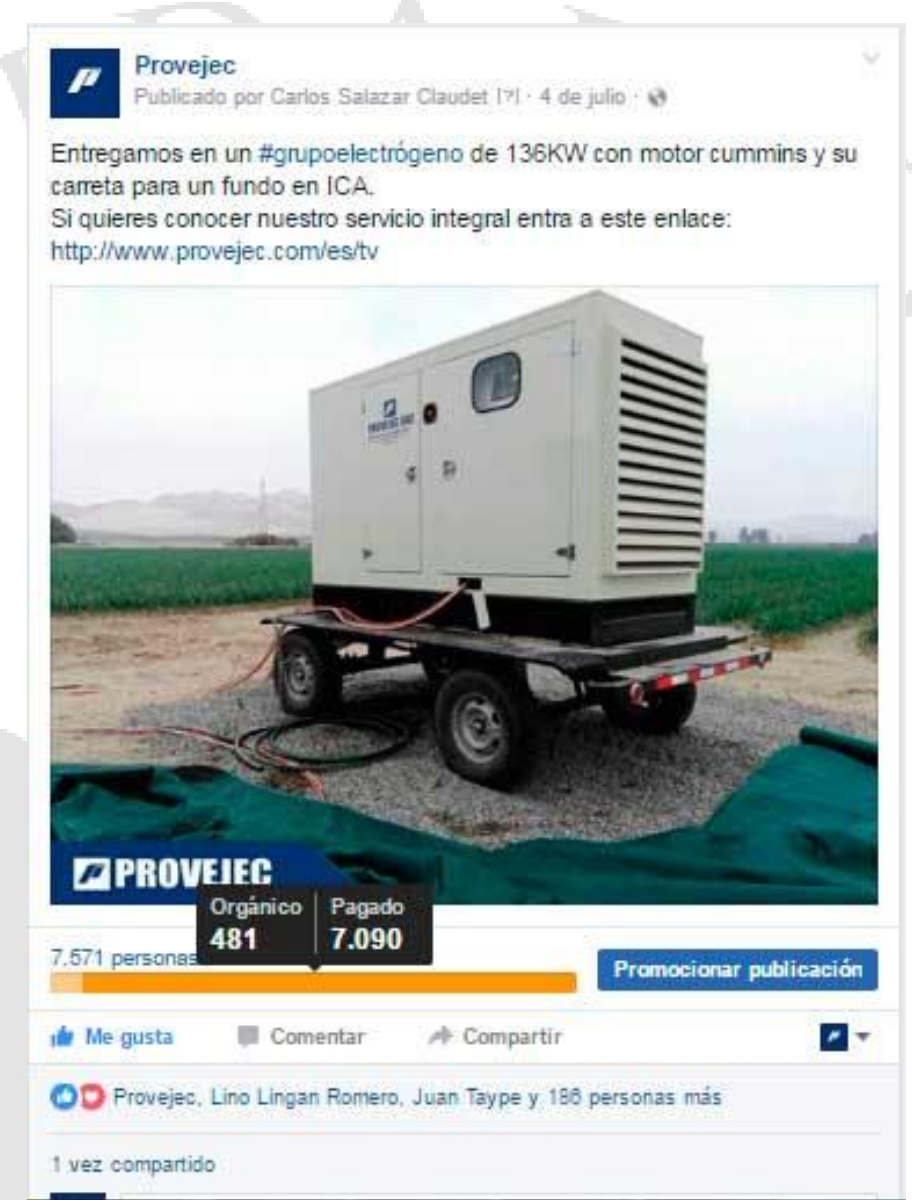

Fuente: captura de pantalla Facebook.

En este caso se mostró un grupo electrógeno suministrado para un fundo en Ica para reforzar el concepto que la empresa llega a todo el Perú. La inversión fue de 20 soles y estas fueron las estadísticas:

\section{Tabla 6.3}

Estadísticas de la publicación de casos de éxito.

\begin{tabular}{|c|c|c|c|c|}
\hline $\begin{array}{c}\text { Alcance } \\
\text { total }\end{array}$ & Reacciones & $\begin{array}{c}\text { Veces que } \\
\text { se compartió }\end{array}$ & $\begin{array}{c}\text { Clicks } \\
\text { en } \\
\text { enlace }\end{array}$ & $\begin{array}{c}\text { Otros } \\
\text { clicks }\end{array}$ \\
\hline 3,245 & 120 & 7 & 33 & 0 \\
\hline
\end{tabular}


Eje contenido: Contenido Viral.

Figura 6.7

Publicación de contenido viral

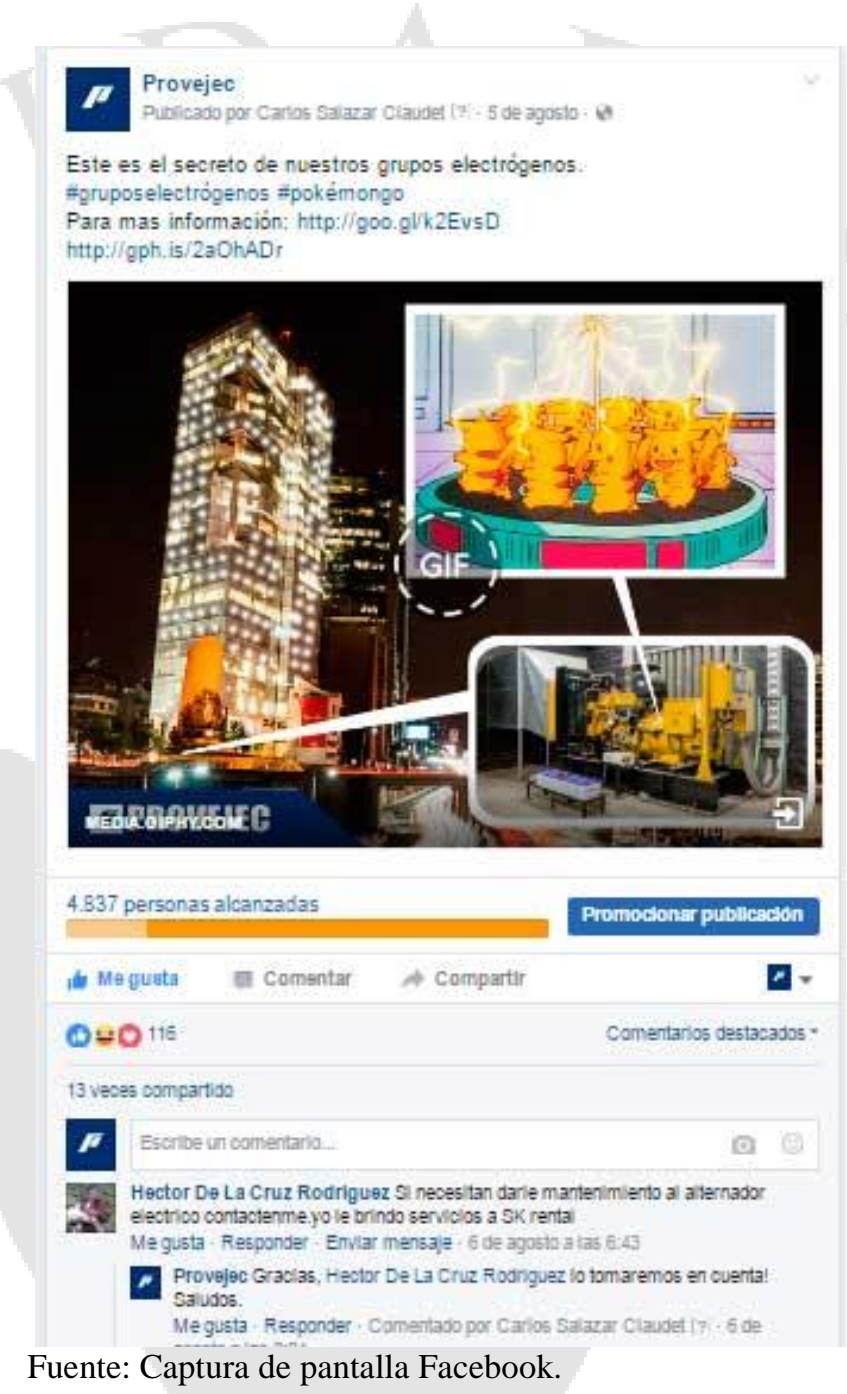

En este caso se publicó contenido relacionado al lanzamiento del popular juego PokemonGo en formato Gif y se vinculó un concepto del juego con el funcionamiento de los grupos electrógenos. La publicación se centro en resaltar la generación de energía del grupo electrógeno. Estos son las métricas de esta publicación: 
Tabla 6.4

Estadísticas de la publicación de contenido viral.

\begin{tabular}{|c|c|c|c|c|}
\hline $\begin{array}{c}\text { Alcance } \\
\text { total }\end{array}$ & Reacciones & $\begin{array}{c}\text { Veces que } \\
\text { se compartió }\end{array}$ & $\begin{array}{c}\text { Clicks } \\
\text { en } \\
\text { enlace }\end{array}$ & $\begin{array}{c}\text { Otros } \\
\text { clicks }\end{array}$ \\
& & & & \\
\hline 4,859 & 168 & 13 & 56 & 54 \\
\hline
\end{tabular}

Eje temático: Servicios.

Figura 6.8

Publicación de servicios.

7 Provejec agregó 4 fotos nuevas

Pultilcado por Provelec Sac [? ? 25 de novienture de 2015 - 6

Nos diferencia nuestro servicio integral. Vendemos el grupo electrógeno, lo instalamos, te capacitamos y realizamos los mantenimientos respectivos. f̈gruposelectrógenos

Si quieres saber como funciona un grupo electrógeno ante la péroida de energía eléctrica de la red comercial entra a este enlace:

http://www.provejec.com/es/tv

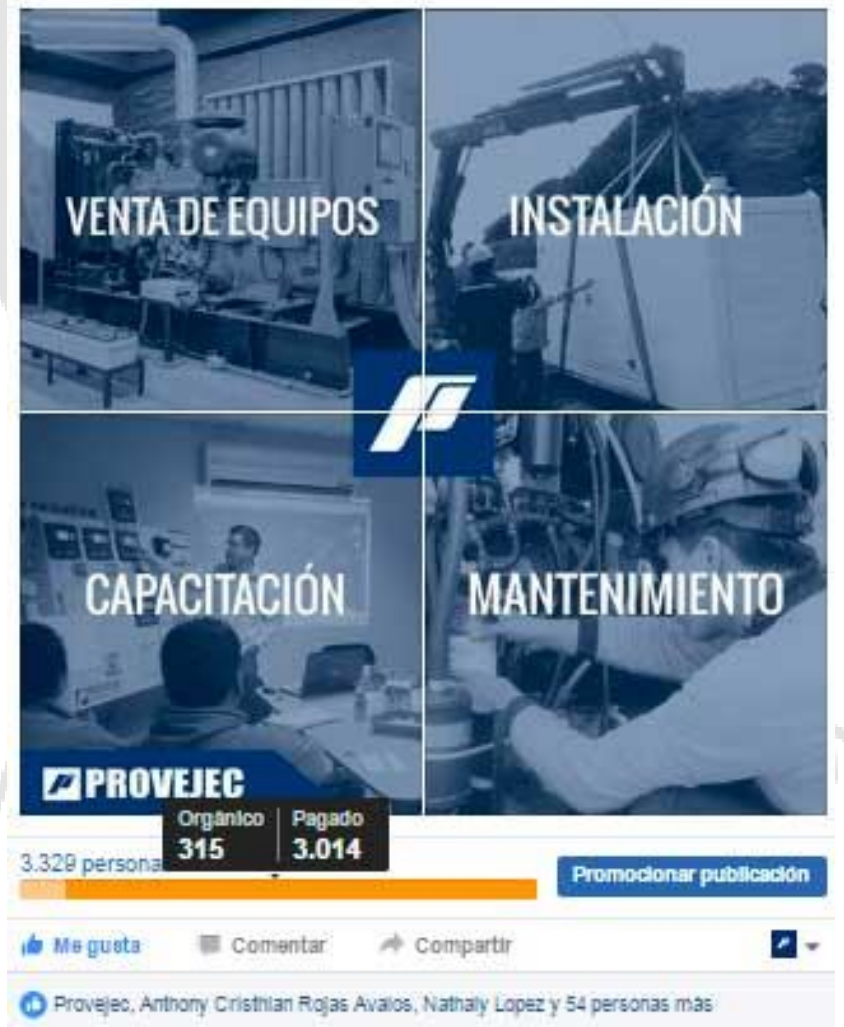

Fuente: Captura de pantalla Facebook. 
Esta publicación se basó en el servicio integral que tiene Provejec que es la diferenciación al resto de la competencia. Se colocó 4 imágenes diferentes y separadas para lograr que el formato de imagen sea mas grande y asi resaltar la publicación. Estos fueron las estadísticas con una inversión de 20 soles:

\section{Tabla 6.5}

Estadísticas de la publicación de servicios.

\begin{tabular}{|c|c|c|c|c|}
\hline $\begin{array}{c}\text { Alcance } \\
\text { total }\end{array}$ & Reacciones & $\begin{array}{c}\text { Veces que } \\
\text { se compartió }\end{array}$ & $\begin{array}{c}\text { Clicks } \\
\text { en } \\
\text { enlace }\end{array}$ & $\begin{array}{c}\text { Otros } \\
\text { clicks }\end{array}$ \\
\hline 3,329 & 66 & 1 & 2 & 16 \\
\hline
\end{tabular}

\subsubsection{Métricas Generales de Facebook}

Estas son las estadísticas generales de la estrategia de contenidos en la red social Facebook.

Tabla 6.6

Métricas generales de Facebook Junio 2015 hasta Octubre 2016.

\begin{tabular}{|c|c|c|c|c|}
\hline Fans & Alcance orgánico & Alcance Pagado & $\begin{array}{c}\text { Reacciones, } \\
\text { comentarios y } \\
\text { veces que se } \\
\text { compartió las } \\
\text { publicaciones }\end{array}$ & $\begin{array}{c}\text { Clicks en } \\
\text { publicaciones }\end{array}$ \\
& & & 3,334 & 5675 \\
\hline 1,739 & 18,927 & 463,881 & & \\
\hline
\end{tabular}


Figura 6.9

Progreso de me gustas del fanpage de Provejec.

Total de Me gusta de la página hasta hoy: 1.739

Total de Me gusta

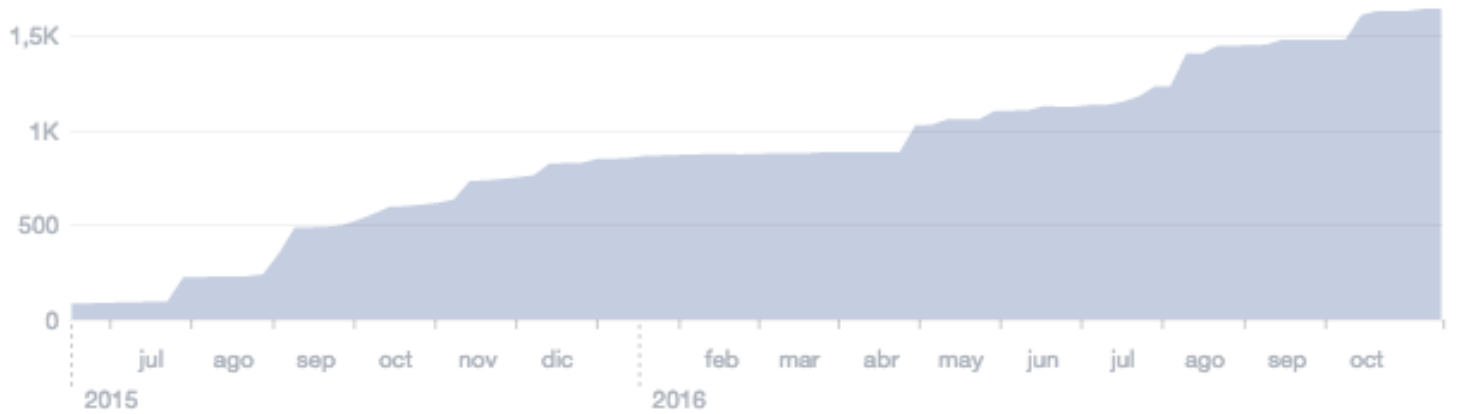

Fuente: captura de pantalla de Facbook.

Esta es la tabla de la evolución de los fans. Como se puede apreciar a lo largo de proyecto el aumento de seguidores se dio de una manera constante logrando obtener una cantidad interesante de seguidores a pesar de la poca inversión.

\subsubsection{LinkedIn}

A continuación presentaré las publicaciones más importantes de cada eje temático del plan de contenidos en LinkedIn. 
Eje tematico: Casos de éxito

Figura 6.10

Publicación LinkedIn sobre caso de éxito.

PROVEJEC SAC Instalación de un grupo de $160 \mathrm{KW}$ para el PNUD. Si quieres saber como funciona un grupo electrógeno entra a este enlace: https//Inkd inveYXTRGq

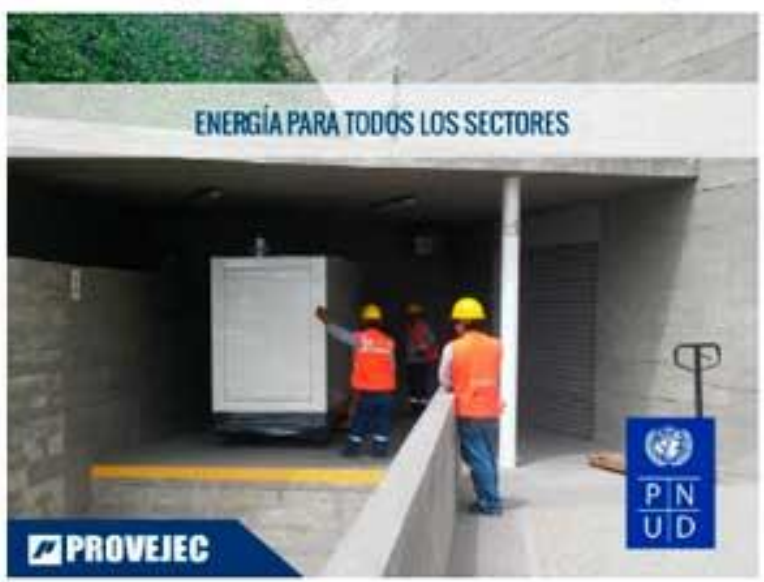

1. General e

Segmentado para: Todos los seguidores

$$
\begin{array}{llll}
344 & 16 & 2 & 5,23 \% \\
\text { impresiones } & \text { clics } & \text { interacciones } & \text { participaciōn }
\end{array}
$$

Fuente: Captura de pantalla.

En este caso se mostró el suministro y el servicio de instalación de un grupo electrógeno para el Programa de las Naciones Unidas. Se colocó un la frase "energía para todos los sectores" para recalcar que los grupos electrógenos que suministra la empresas se venden a todos los sectores. La pauta fue de 14 dólares por un día y estos fueron los resultados estadísticos: 
Tabla 6.7

Métricas de la publicación casos de éxito.

\begin{tabular}{|c|c|c|c|c|}
\hline Impresiones & $\begin{array}{c}\text { Clics en el } \\
\text { anuncio y/o } \\
\text { página. }\end{array}$ & $\begin{array}{c}\text { Acciones } \\
\text { sociales }\end{array}$ & Recomendaciones & $\begin{array}{c}\text { CTR } \\
\text { Medio }\end{array}$ \\
\hline 2,213 & 8 & 4 & 2 & 0,362 \\
\hline
\end{tabular}

Eje temático: Servicio integral.

Figura 6.11

Publicación de LinkedIn sobre el servicio integral.

PROVEJEC SAC Nos diferencia nuestro servicio integral. Vendemos el grupo electrógeno, lo instalamos, te capacitamos y realizamos los mantenimientos respectivos. Si quieres saber como funciona un grupo electrógeno ante la pérdida de energía eléctrica de la red ... más

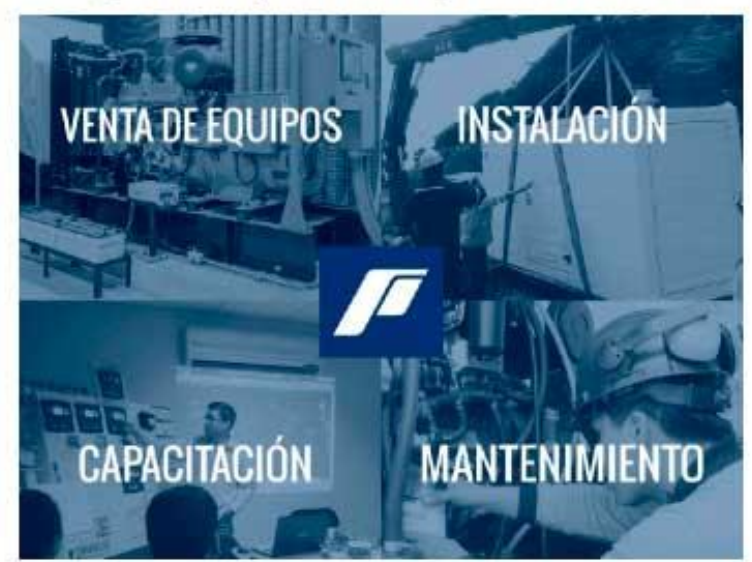

I. General ?

Segmentado para: Todos los seguidores

\begin{tabular}{|c|}
\hline $\begin{array}{l}69 \\
\text { ipresiones }\end{array}$ \\
\hline
\end{tabular}

Fuente: captura de pantalla.

En LinkedIn también se mostró el servicio integral que tiene provejec con respecto al resto de la competencia. Se utilizó al igual que en facebook 4 imágenes juntas para mostrar los productos y servicios. Estas fueron las estadísticas: 
Tabla 6.8

Métricas de la publicación de servicio intergral.

\begin{tabular}{|c|c|c|c|c|}
\hline Impresiones & $\begin{array}{c}\text { Clics en el } \\
\text { anuncio y/o } \\
\text { página. }\end{array}$ & $\begin{array}{c}\text { Acciones } \\
\text { sociales }\end{array}$ & Recomendaciones & $\begin{array}{c}\text { CTR } \\
\text { Medio }\end{array}$ \\
\hline 3,284 & 6 & 5 & 2 & 0,183 \\
\hline
\end{tabular}

Eje temático: Noticias relacionadas al rubro

Figura 6.12

Publicación LinkedIn de noticias relacionadas al rubro.

PROVEJEC SAC ¡Genial idea! https://lnkd.in/eCzguQy

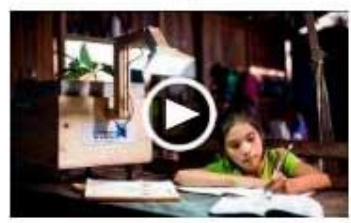

Planta lámparas UTEC, plantas que dan luz

youtube.com - Luego de un largo proceso de investigación y

desarrollo de prototipos por profesores y alumnos de UTEC, el

resultado obtenido como propuesta de solución fue la

Plantalámpara, un modelo de aplicación que integra energia limpia

y autosostenible,...

Il. General (3)

Segmentado para: Todos los seguidores

\begin{tabular}{|c|c|c|c|}
\hline $\begin{array}{l}400 \\
\text { impresiones }\end{array}$ & $\begin{array}{l}16 \\
\text { clics }\end{array}$ & $\begin{array}{l}\mathbf{0} \\
\text { interacciones }\end{array}$ & $\begin{array}{l}4,00 \% \\
\text { participacion }\end{array}$ \\
\hline Patrocinar & tualiza & & \\
\hline
\end{tabular}

Recomendar - Comentar * Hace 11 meses

Fuente: captura de pantalla.

En este caso fue la publicación de una noticia relacionada al rubro de energía, no tuvo pauta porque el objetivo de la publicación de noticia era recordación de la marca y no obtener conversiones. 
Eje tematico: Brading de la marca.

Figura 6.13

Publicación LinkedIn branding de a marca.

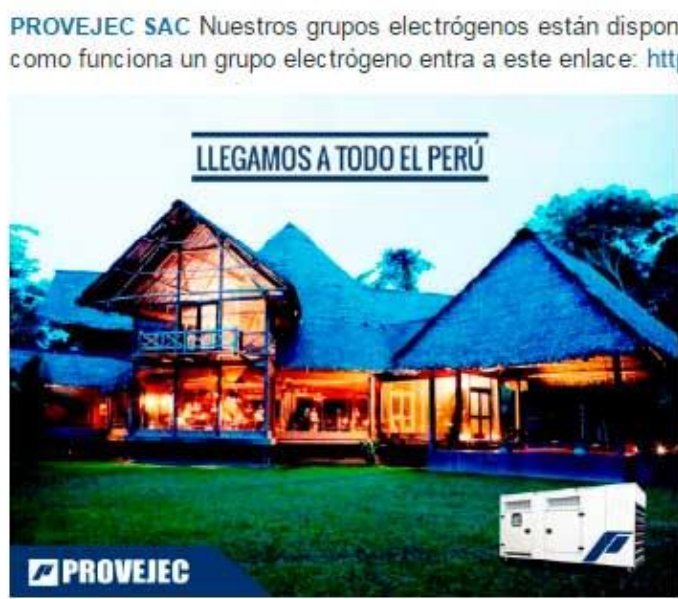

I. General (?)

Segmentado para: Todos los seguidores

$\begin{array}{llll}378 & 7 & 1 & 2,12 \% \\ \text { impresiones } & \text { clics } & \text { interacción } & \text { participación }\end{array}$

Fuente: captura de pantalla.

En esta publicación se resaltó que Provejec suministra grupos electrógeno en todo el Perú. Se colocó la imagen de un hotel lujoso en medio de la selva con la luces prendidas. La inversión fue de 14 dólares y los resultados de la publicación fueron estos:

Tabla 6.9

Métricas de la publicación sobre branding.

\begin{tabular}{|c|c|c|c|c|}
\hline Impresiones & $\begin{array}{c}\text { Clicks en el } \\
\text { anuncio y/o } \\
\text { página. }\end{array}$ & $\begin{array}{c}\text { Acciones } \\
\text { sociales }\end{array}$ & Recomendaciones & $\begin{array}{c}\text { CTR } \\
\text { Medio }\end{array}$ \\
\hline 1243 & 6 & 4 & 1 & $0,647 \%$ \\
\hline
\end{tabular}




\subsubsection{Estadistica generales de la camapaña en LinkedIn.}

Tabla 6.10

Métricas generales de la campaña de LinkedIn Junio 2015 hasta Octubre 2016.

\begin{tabular}{|l|l|l|l|l|l|l|l|}
\hline Impresiones & Clics & $\begin{array}{l}\text { CTR } \\
\text { medio }\end{array}$ & $\begin{array}{l}\text { Acciones } \\
\text { sociales }\end{array}$ & $\begin{array}{l}\text { Interacción } \\
\text { total }\end{array}$ & $\begin{array}{l}\text { Interacción } \\
\text { media }\end{array}$ & $\begin{array}{l}\text { CPC } \\
\text { medio }\end{array}$ & $\begin{array}{l}\text { CPM } \\
\text { medio }\end{array}$ \\
\hline 47.305 & 178 & $0,376 \%$ & 106 & 284 & $0.6 \%$ & 1.61 USD & 6,06 USD \\
\hline
\end{tabular}

\subsection{Validación SEO}

Gracias a la estrategia para los resultados de búsqueda orgánica se logró que el sitio web de Provejec se ubique dentro de los 10 primeros resultados orgánicos con las palabras clave de los productos principales. Para llegar a estos resultados coloqué 4 veces cada palabra clave en la barra de búsqueda de Google.

Tabla 6.11

Posiciones orgánicas de las principales palabras clave.

\begin{tabular}{|l|c|}
\hline \multicolumn{1}{|c|}{ Palabra clave } & Posicionamiento orgánico \\
\hline Grupos electrógenos Perú & Entre la 4 y 9 posición \\
\hline Grupos electrógeno biogas & Entre 2 y 4 posición \\
\hline Tableros de transferencia & Entre la 1 y 2 posición \\
\hline Carretas para grupos electrógenos & 2 posición \\
\hline Deep sea electronics peru & 1 posición \\
\hline Encapsulado insonorizado & 2 posición \\
\hline Modulo control para grupos electrógeno & Entre la 2 o 3 posición. \\
\hline Tanques de combustible & \\
\hline
\end{tabular}

\subsection{Validación de las estadísticas del sitio web.}

A continuación se presentará las estadísticas de Google Analytics desde que el nuevo sitio web estuvo colgado hasta la fecha de elaboración de este proyecto (Junio 2015 Octubre 2016). 
Figura 6.14

Gráfico general de las estadísticas web.

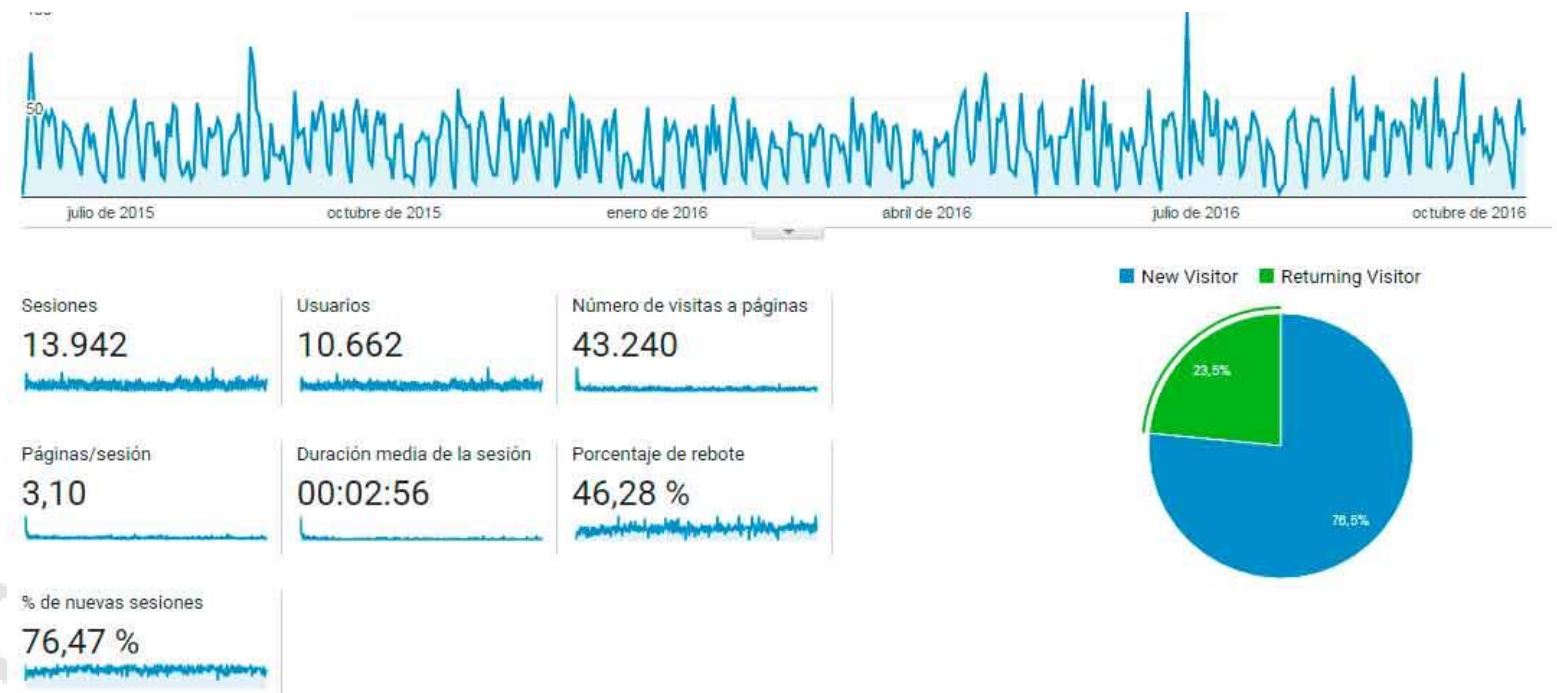

Fuente: captura de pantalla Google Analytcis

Tabla 6.12

Métricas generales del sitio web.

\begin{tabular}{|l|l|l|l|l|l|l|}
\hline Sesiones & Usuarios & $\begin{array}{l}\text { Número de } \\
\text { visitas a } \\
\text { páginas }\end{array}$ & $\begin{array}{l}\text { Páginas por } \\
\text { sesiones }\end{array}$ & $\begin{array}{l}\text { Duración } \\
\text { media de la } \\
\text { sesión }\end{array}$ & $\begin{array}{l}\text { Porcentaje } \\
\text { de rebote }\end{array}$ & $\begin{array}{l}\text { de nuevas } \\
\text { sesiones }\end{array}$ \\
\hline 13,942 & 10,662 & 43,240 & 3,10 & $2: 56$ & $46,28 \%$ & $76,47 \%$ \\
\hline
\end{tabular}

Como se puede apreciar en estos cuadros el porcentaje tráfico de nuevos visitantes es alto y esto se asocia a que son nuevos clientes en busca de los productos de la empresa. 
Figura 6.15

Canales de entrada al sitio web.

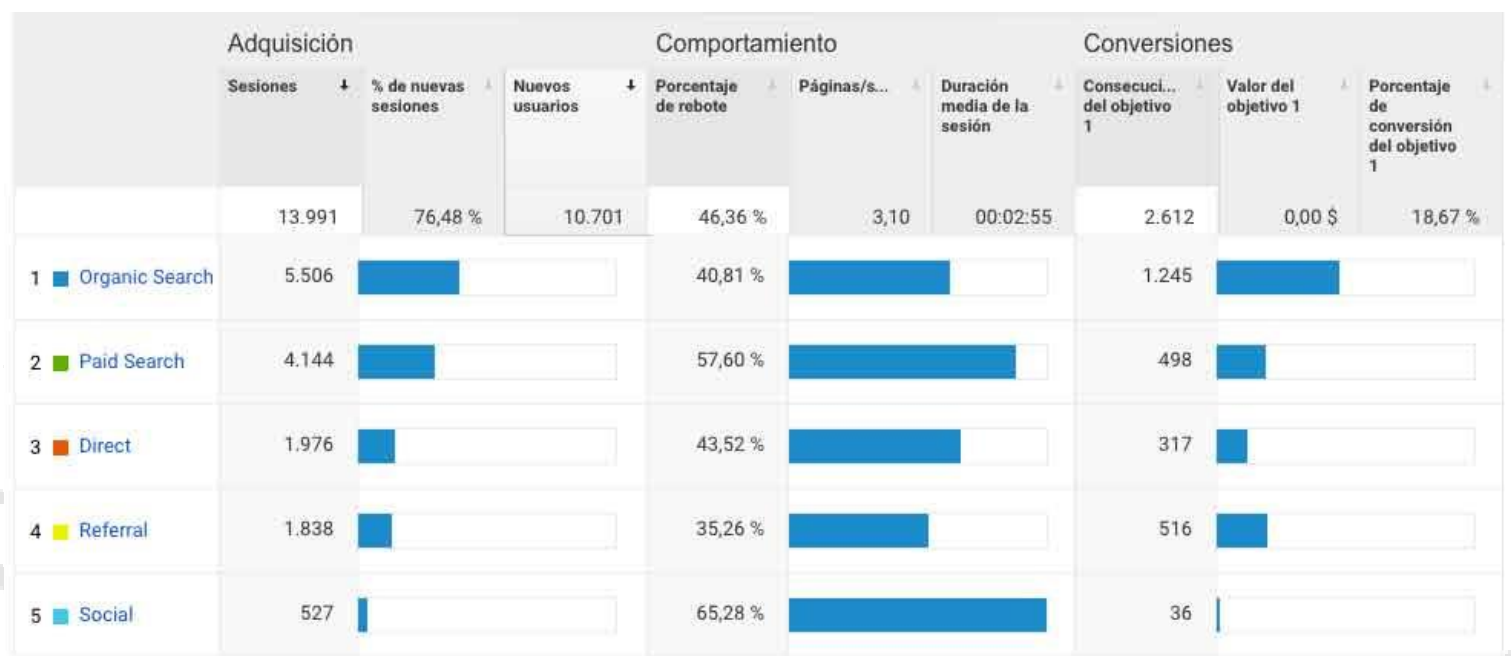

ara ver todns ins 5 fanales hana clin anu

Fuente: captura de pantalla de Google Analytics.

Como se puede apreciar en este gráfico el primer canal de adquisición fue la búsqueda orgánica, en segundo lugar la publicidad de Google Adwords, en tercer lugar personas que pusieron directamente en la barra del explorador la dirección del sitio web, en cuarto lugar enlaces desde otras páginas webs y por último usuarios que llegaron desde las redes sociales.

Se configuró la opción de plantear un objetivo en Google Analytics. El objetivo de conversión fue cuantos usuarios llegaban a la página de contacto, ya que en esa sección se encontraba los números telefónicos de la empresa y el formulario para solicitar cotizaciones o realizar consultas. Los resultados del objetivo se pueden apreciar en la figura 6.15 . 
Figura 6.16

Número de visitas de cada página.

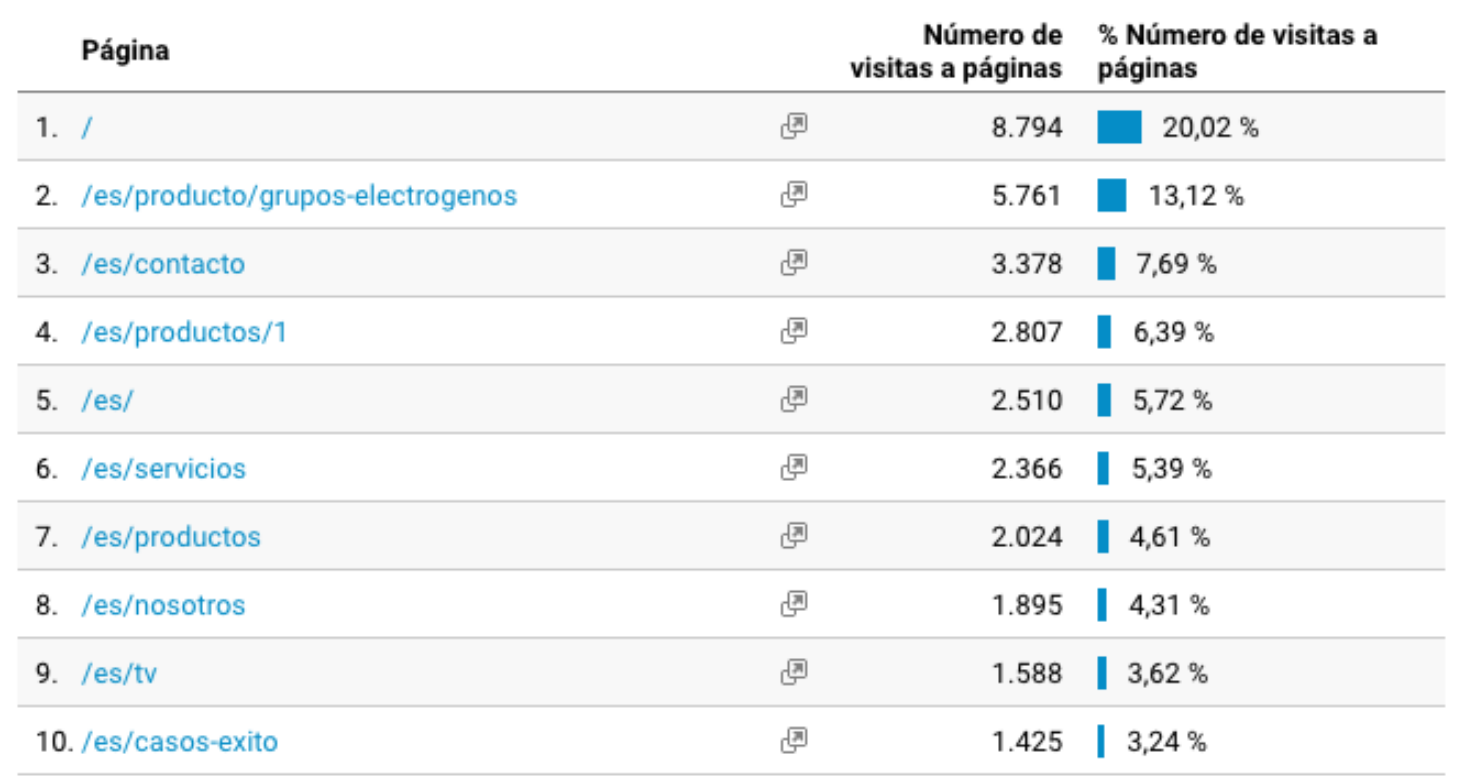

Fuente: Captura de pantalla de Google Analityc.

\subsection{Validación de solicitudes de cotización por el canal digital.}

Las métricas expuestas anteriormente son impactos no financieros que según Blanchard (2012) no forman parte del ROI de la empresa. El siguiente cuadro es el registro estadístico de la cantidad de solicitudes de cotización que llegó por medio de los canales digitales a lo largo del proyecto sin contar las llamadas directas al número fijo de la empresa. Según el mismo autor la manera de relacionar los resultados no financieros al ROI es por medio de la conversiones que los impactos no financieros (me gustas, compartidos, número de visitas al sitio web, etc.) lograron. En este caso cada solicitud de cotización que llegó por los diferentes canales digitales es una conversión. Fueron 340 solicitudes de cotización a lo largo de todo el proyecto (16 meses). 
Tabla 6.13

Número de solicitudes de cotización.

\begin{tabular}{|l|c|c|c|}
\hline & Formulario web & Chat web & $\begin{array}{c}\text { Facebook (Inbox - } \\
\text { Comentarios) }\end{array}$ \\
\hline $\begin{array}{l}\text { Solicitudes de } \\
\text { cotización (Junio 2015 } \\
- \text { Octubre 2016). }\end{array}$ & 248 & 70 & 22 \\
\hline
\end{tabular}

En la siguiente parte del este proyecto fundamentaré teóricamente todas las acciones implementadas en la estrategia digital de Provejec. 


\section{CAPÍTULO VII: FUNDAMENTACIÓN CONCEPTUAL}

\subsection{Importancia del internet para las empresas.}

Luego de ver los indicadores logrados de la estrategia digital, en este capítulo fundamentaré la importancia de tener presencia en internet para las empresas. Internet ha revolucionado el campo del marketing y la comunicación comercial. Desde su creación y posteriormente el auge de la nuevas tecnologías, la digitalización se ha vuelto fundamental para las empresas y sus estrategias de marketing. Las empresas que sobreviven son las que se adaptan a estas nuevas formas de hacer llegar la información a los clientes. No estando en internet disminuyen las oportunidades de crecimiento, las ventajas competitivas y la credibilidad de la empresa. Cada vez más los usuarios que están en internet aumentan, en la red se puede encontrar a los clientes, proveedores, competidores y prácticamente todos los stakeholders de la empresa (Redondos y Rojas, 2013; Rosales, 2010; Somalo, 2011)

Para el caso de Provejec, empresa del sector industrial eléctrico, que no tiene un público objetivo masivo, la ventaja de estar en internet a diferencia de los medios tradicionales es tener la posibilidad de tener una segmentación bien específica y poder personalizar el contenido. La personalización del contenido en social media y la segmentación específica para el público objetivo fue lo que se aplicó a lo largo del proyecto.

Para Redondos y Rojas (2013) las empresas al adaptarse a los cambios impuestos por internet han mutado a ser empresas sociales:

Las redes sociales, y en cierta forma la tecnología basada en las herramientas de la web 2.0, han permitido que algunas organizaciones hayan seguido un nuevo rumbo y no sólo se han adaptado a las nuevas corrientes sociales, sino que han mutado en todos los sentidos convirtiéndose en verdaderas empresas sociales. (p. 15)

A raíz de esta revolución digital de la información el consumidor actual ha cambiado, las nuevas herramientas le permiten estar mucho más informado, pueden buscar información sobre alguna empresa o marca. Este nuevo consumidor es mucho más exigente, ya que dispone de la información a cualquier hora y en cualquier lugar (Rosales, 2010). 
El cliente o usuario al estar en las redes sociales y/o utilizar los motores de búsqueda para encontrar productos o servicios ha hecho que las estrategias intrusivas del marketing tradicional cambien a un marketing inbound como lo explica García (2012):

Frente a estas técnicas de marketing tradicionales e intrusivas, nacen, como evolución lógica a raíz de la web 2.0, las que denominamos marketing inbound, todas aquellas tácticas, acciones y estrategias que consiguen captar y fidelizar a nuestros clientes sin ser intrusivos, sin ir a ellos, sino facilitándoles a través de canales, medios y herramientas varias, que nos encuentren. Es decir, hemos pasado de ir por el cliente de forma masiva, a conseguir que sea él mismo quien venga a nosotros, utilizando técnicas denominadas push/empujar (outbound) frente a pull/atraer (inbound) el principal fin es dirigir tráfico a nuestro sitio web. (p. 59)

\subsection{Desarrollo de sitios web. Experiencia del usuario y Accesibilidad.}

En este capítulo desarrollaré las características principales que todo sitio web debe tener, ya que en Provejec se gestionó la elaboración de un sitio web totalmente nuevo y era necesario que tenga las últimas tendencias de diseño, usabilidad web y experiencia del usuario.

El sitio web de las empresas es su principal carta de presentación en internet. Los sitios web según los diversos autores tienen que tener ciertas características para que los usuarios o clientes puedan encontrar con facilidad información, dar una buena impresión y tener una buena experiencia del usuario.

La clave para tener un buen sitio web es comprender a los clientes o usuarios, contar con un buen diseño, buena navegación y tener la tecnología adecuada, estos factores son fundamentales para que un sitio web sea óptimo (Scott, 2010).

De a acuerdo Jakob Nielsen (Como se citó en Chaffey y Ellis-Chadwick, 2014) una característica fundamental para la fácil navegación y por ende una buena experiencia del usuario es la funcionalidad del sitio web que la define como un enfoque de ingeniería del diseño de los sitios web para asegurar que la interfaz del sitio pueda ser recordada, sea eficiente y otorgue satisfacción al cliente. Los usuarios podrían 
abandonar los sitios web si son difíciles de usar, si el sitio web no muestra lo que ofrece la empresa o si se pierden dentro de este. Una buena funcionalidad potencia al sitio web y lo hace más amigable, esto conlleva a que el usuario o cliente regrese.

Un concepto equivalente a la funcionalidad web que platean Maciá y Gosende (2010) es la usabilidad web. Este concepto tiene cuatro aspectos a resaltar. El primero es que el sitio web tiene que estar diseñado para los "futuros usuarios a los que va dirigido el sitio web" (p. 83). Segundo que el sitio web tiene que cumplir los objetivos estratégicos para lo cual fue diseñado como por ejemplo: una venta, un usuario registrado, una solicitud de cotización, etc. Tercero plantean el concepto de "escenarios de uso" que lo definen como la capacidad que el sitio web pueda ser apreciado y usado en cualquier condición técnica o de otro tipo. Por último la experiencia del usuario tiene que ser positiva, el proceso para alcanzar los objetivos de los usuarios debe ser intuitivo, sencillo, rápido y eficiente para lograr la satisfacción del cliente. (pp. 83-85)

Por consiguiente, para tener una buena usabilidad web en términos de diseño: el menú de navegación se tiene que encontrar e identificar fácilmente, los textos que son botones de enlaces tienen que estar claramente señalizados por subrayados o con diferentes colores, los formularios tienen que presentar secciones pertinentes, etc. (Maciá y Gosende, 2010).

También es importante tener una buena organización de todos los elementos para que repercuta en la usabilidad; el contenido no puede estar sobrecargado; el diseño de cada página del sitio web tiene que estar en función al barrido visual de los usuarios; la distribución de los elementos de información y navegación deben estar distribuidos en zonas de mayor o menor jerarquía visual según su relevancia (Hassan, Fernández y Iazza, 2004).

De la misma manera, la organización de la información que se muestra en el sitio web es una característica sustancial para una buena usabilidad o funcionalidad web, por ejemplo en el caso de Provejec que comercializa gran variedad de productos del rubro eléctrico es importante separarlos por categorías para facilitar la búsqueda del usuario. Esta organización de la información para Rosenfeld y Morville (como se citó en 
Chaffey y Ellis-Chadwick, 2014) la denomina como arquitectura de la información y lo define como:

1. La combinación de esquemas de organización, etiquetado y navegación que constituyen un sistema de información.

2. El diseño estructural de un espacio de información para facilitar la realización de tareas y el acceso intuitivo al contenido.

3. El arte y la ciencia de estructurar y clasificar sitios web e intranets de manera que ayuden a la gente a encontrar y manejar la información. (p.391)

Para crear la estructura de la distribución de la información del sitio web es importante plantear un mapa de sitio y posteriormente determinar las conexiones internas de cada página del sitio web.

Figura 7.1

Sitemap

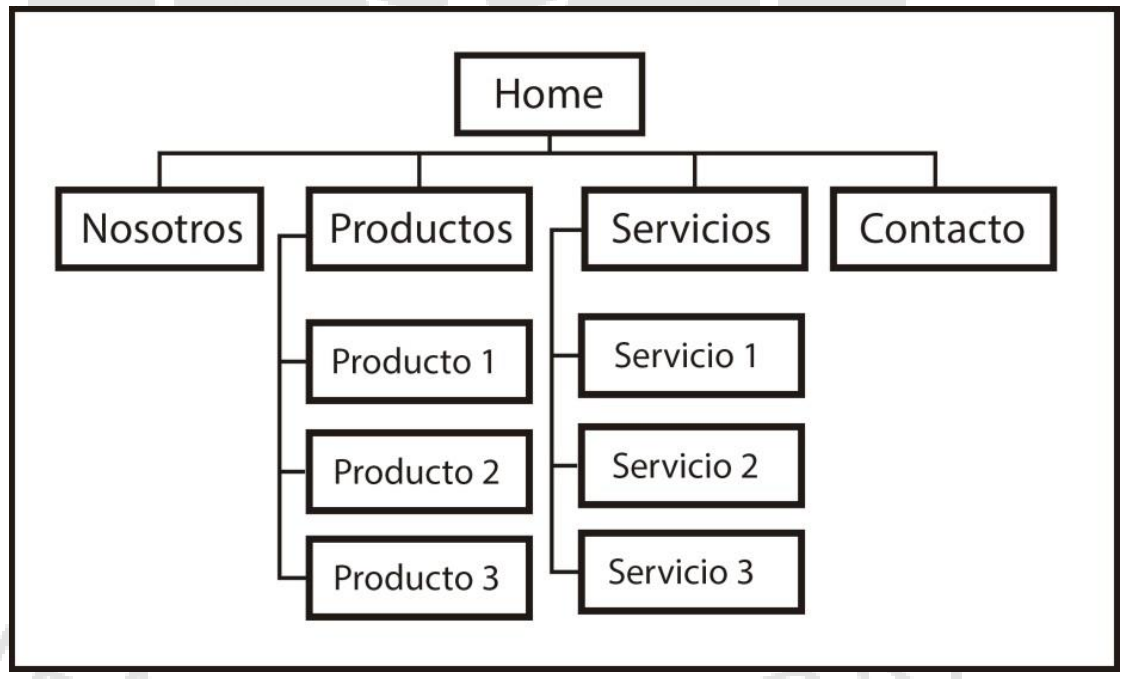

Fuente: Elboración propia.

Por lo tanto, según Maciá y Gosende (2010) existen tres tipos de estructura de un sitio web para organizar la información: 
El modelo secuencial: el contenido del sitio web se ordena de manera secuencial. El contenido puede ser ordenado cronológicamente, por un orden lógico, alfabéticamente, etc. Este tipo de modelo es preciso para sitios web de formación, donde los usuarios son conducidos a través de una serie de lecciones consecutivas a través de un esquema de navegación lineal.

El modelo jerárquico: el contenido se organiza de lo más general a lo más específico con una página de entrada principal de la cual se desarrollan secciones en niveles subyacentes. Este esquema es más habitual para páginas web de empresas ya que es sencillo de aprender.

El modelo en red: el objetivo en este tipo de estructura es incentivar el pensamiento asociativo y favorecer el libre flujo de las ideas, permitiendo que los usuarios persigan sus intereses de acuerdo con un patrón único. Las estructuras en red pueden resultar confusas para los usuarios. (p. 91)

\section{Figura 7.2}

\section{Modelo secuencial}

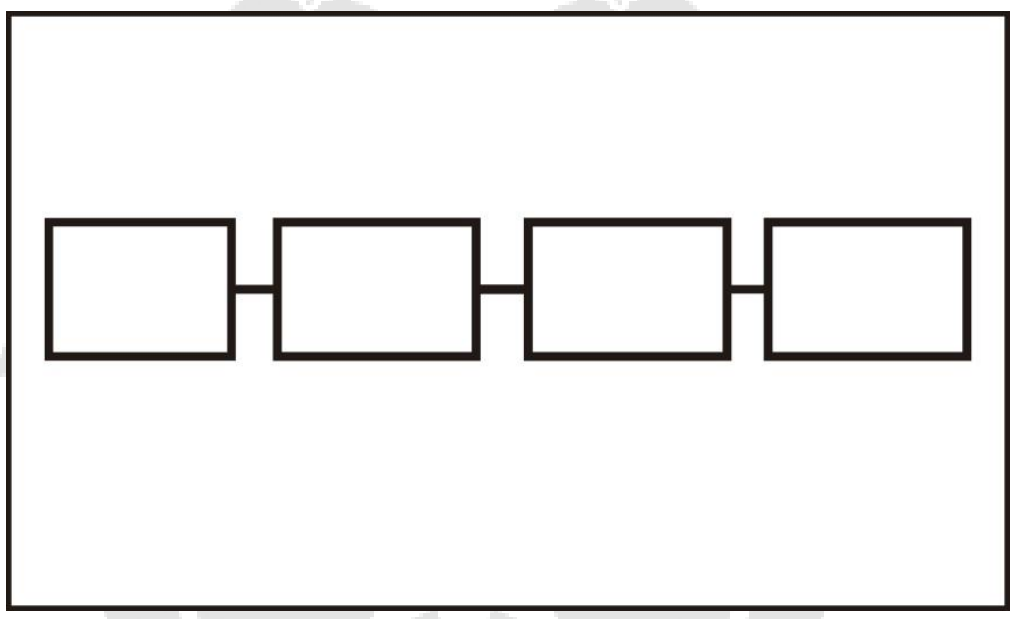

Fuente: elaboración propia

Figura 7.3

Modelo jerárquico.

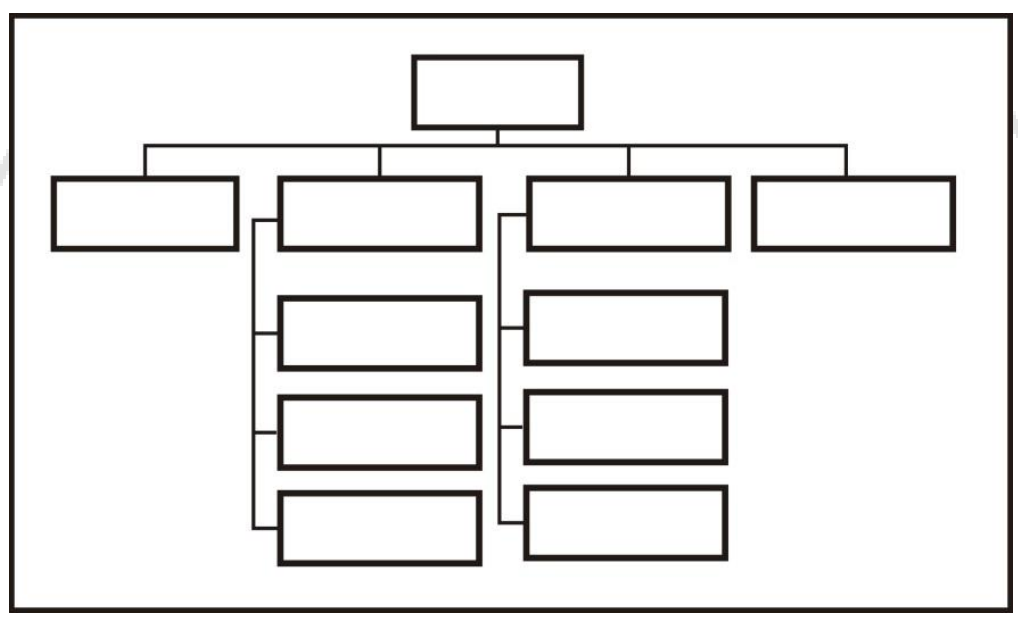


Fuente: elaboración propia

Figura 7.4

Modelo Red

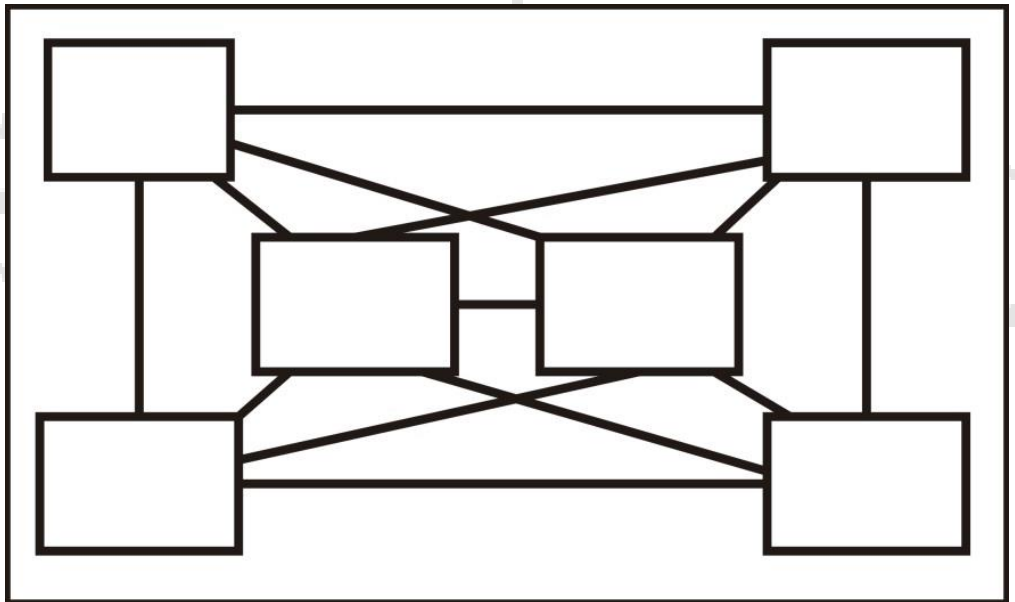

Fuente: elaboración propia.

Sin embargo; la mayoría de los sitios comparten características de los tres modelos de estructura, lo usual es que los usuarios naveguen por el sitio web libremente más parecido al modelo en red (Maciá y Gosende 2010). Es importante implementar todas estas características expuestas en el sitio web de la empresa, más aún cuando la empresa cuenta con varios productos para mostrar y gran cantidad de información relevante para el cliente.

Por otro lado, es fundamental que todos los elementos de cada página del sitio web apunten a lograr los objetivos planteados: atraer tráfico, conducir tráfico hacia la página de conversión, mostrar información, etc. Es por esto que el diseño del aspecto visual y la estructura del contenido de cada página juegan un rol fundamental para la usabilidad (Maciá y Gosende, 2010).

Por consiguiente, las fotografías son un elemento del aspecto visual del sitio web y en la mayoría de casos es lo que el usuario observa en primera instancia y tienen un rol fundamental, ya que son una forma de expresión muy poderosa, cuando las imágenes son un componente integrado del sitio web (Scott, 2010). En el caso de Provejec que comercializa productos industriales del rubro eléctrico y sus derivados es una gran 
ventaja contar con imágenes de buena calidad y resolución ya que le da atractivo a los productos.

Por otro lado, los contenidos textuales del sitio web se tienen que mostrar lo más concisos, precisos y creativos posibles, es importante seguir una estructura piramidal en los textos (lo más importante del mensaje debe ir primero), permitir una fácil exploración del contenido, cada párrafo debe tener una idea, utilizar un lenguaje amigable y comprensible para el usuario (Hassan, Fernández y Iazza, 2004). Este aspecto toma más relevancia cuando los textos de los catálogos de los productos normalmente son explicados con palabras técnicas, la descripción de los productos en el sitio web tiene que estar escrita para que cualquier persona pueda entenderla.

El objetivo principal del contenido es atraer usuarios y convertirlos en clientes fieles es por esto que tiene que ser lo suficientemente relevante para el usuario. Scott (2010) afirma que: "los mejores sitios web se centran principalmente en el contenido, con el fin de unificar a los distintos compradores, nichos de mercado, medios de comunicación y productos en un sitio atractivo y completo en donde el contenido además de ser el rey, también presida y gobierne" (p. 150).

Asimismo, un sitio web no sólo debe de contar con contenido estático (textos e imágenes), el contenido también puede ser dinámico, ya que estimula la interacción del usuario. Los videos, podcasts, el contenido generado por los usuarios también se deben tener en cuenta para la atracción de clientes (Chaffey y Ellis-Chadwick, 2014). En el caso de Provejec que su sitio web contenga contenido audiovisual es un aporte importante ya que puede mostrar la modalidad de trabajo de la empresa y eso genera confianza para el cliente.

Como se profundizará en los siguientes capítulos la creación de contenido de calidad y relevante para el usuario es una excelente estrategia de atracción para captar clientes y un factor fundamental para la usabilidad y la experiencia del usuario, pero para lograr esto es necesario que el sitio web tenga un sistema de administración de contenidos.

Por lo tanto, para Chaffey y Ellis-Chadwick (2014) un sistema de administración de contenidos tiene que tener las siguientes características: 
- Fácil sistema autoría: se debe permitir la edición de documentos, texto, imágenes.

- Rastreo mediante robots en los motores de búsqueda: el contenido almacenado en el sitio web debe poder ser indexado por los motores de búsqueda.

- Administración de vínculos. El mantenimiento de vínculos internos y externos mediante el cambio de contenido y la eliminación de vínculos obsoletos.

- Uso de plug-in widget: Se debe poder vincular las redes sociales de la empresa.

- Rastreo y monitoreo: que el sitio web se pueda enlazar a las herramientas de análisis web como Google Analytics.

La accesibilidad es otro requerimiento básico para una buena experiencia del usuario. La accesibilidad permite que los usuarios puedan acceder e interactuar con el sitio web independientemente de alguna característica especial que tengan, el explorador web o la plataforma que utilicen para acceder al sitio (Ibid).

Debido al auge de los smartphones y las tablets es necesario que los sitios web implanten técnicas como en el diseño web adaptativo (responsive), esta técnica se basa en que la interfaz de la página web se adapte a cualquier tamaño de pantalla sin alterar la usabilidad (Ibid). Para el sitio web Provejec era de suma importancia tener el diseño responsive, ya que era muchas personas navegan en internet desde los celulares o tablets.

Los beneficios que el sitio web tenga una buena accesibilidad para Maciá y Gosende (2010) son:

- Económicas: más usuarios significa más ventas.

- Compatibilidad: los sitios web accesibles son más compatibles con una mayor variedad de terminales de sobremesa, móviles y resoluciones de pantalla. 
- Mejora en los tiempos de descarga: La maquetación con hojas de estilo CSS aligera el peso total de la página y hace el proceso de descarga se más rápida.

- Mejora el posicionamiento: Google y los motores de búsqueda premia a los sitios webs con una buena experiencia del usuario y accesibilidad.

\subsection{Social Media y las empresas. Community Managment}

En este capítulo se desarrollará todo lo que conlleva que una empresa esté presente en social media, ya que Provejec no contaba con un buen manejo de sus redes sociales ni un plan de contenidos. Es importarte tener presencia en social media porque la mayoría de productos y servicios ofrecidos son de montos considerables y era necesario tener una constante interacción con los clientes para que se genere confianza con la empresa.

Los social media son un conjunto de plataformas digitales en las cuales los usuarios pueden interactuar y compartir contenido con otros usuarios en tiempo real. Los seres humanos por naturaleza somos seres sociales, constantemente estamos compartiendo historias, experiencias y nos encanta pertenecer grupos a sociales. Actualmente los social media forman parte de nuestra vida, ya que nos ayudan a conectarnos entre nosotros y llenar esa necesidad de la naturaleza humana.

Por consiguiente, es importante que las empresas sepan comprender que los usuarios o clientes finales han cambiado a raíz de los social media y seguirán constantemente haciéndolo en una dirección: la interacción, participación, democratización y colaboración. No sólo se trata de informar a nuestros clientes sino también de hacerlos participes y hacerlos entender que ahora más que nunca ellos son lo que importan y no nuestra empresa (Garcia, 2012). Actualmente es difícil encontrar clientes dispuestos a recibir pasivamente la información de una empresa, los social media le han dado al usuario la posibilidad de participar y poder opinar cuándo y cómo quiera (Rodriguez, 2012).

Tal como lo señala Blanchard (2012), las economías de escala y las automatizaciones de los procesos habían hecho que los consumidores se vean como meros números y por ende "las relaciones especiales entre los clientes y las empresas sean difíciles de 
mantener" (p. 23). Pero gracias a los social media se ha creado lo que actualmente se llama el "negocio social" o "empresa social" y volvió el antiguo paradigma de construir nuevamente relaciones con los clientes. (p. 23)

Tener presencia en social media puede brindar muchas ventajas a la empresa. Lo que le puede brindar un programa de social media a la empresa para Blanchard (2012) es feedback detallado e instantáneo de los clientes mediante las herramientas de control, medición y análisis; puede limpiar y proteger a una marca en crisis; influenciar a los consumidores a que elijan una marca o producto; mostrar a los usuarios de la existencia de una empresa; mostrar nuevos productos, etc. (p.26) En el caso de Provejec sirve para obtener estadísticas del comportamiento de los clientes, promocionar los productos y obtener conversiones

Asimismo, con la web 2.0 y la redes sociales, las empresas tienen la posibilidad de responder a los clientes lo más rápido posible hasta incluso en tiempo real por medio del chat. Esto ha hecho que mejore considerablemente la eficiencia del servicio de atención al cliente sin necesidad de aumentar el costo. Otra ventaja de optar por el modelo de atención al cliente por medio de los social media es que los tiempos de resolución son inmediatos con respecto a los medios tradicionales y por ende el cliente va a estar contento evitando esperar en el teléfono y obteniendo la información al instante (Blanchard, 2012). Como se pudo ver anteriormente en el caso de Provejec llegaron solicitudes de cotización por medio de inbox del Facebook y de chat implementado en el sitio web.

El aumento de ventas por el canal de social media no es ajeno a la mejora en las empresas. Los social media ayudan a obtener nuevos clientes por medio del alcance y la influencia. Los usuarios son conscientes de la existencia de la marca, empiezan a participar en los social media de la empresa para luego convertirse en clientes (Blanchard, 2012).

Por otro lado, el objetivo principal de las empresas ante cualquier inversión en general es medir el retorno de la inversión (ROI). Muchos autores plantean que existe ROI en social media y lo relacionan con los resultados no monetarios pero para Blanchard 
(2012) el ROI se mide netamente con lo que se puede cuantificar, es una ecuación simple que mide el retorno de la inversión en términos netamente monetarios:

$\mathrm{ROI}=($ ganancia de la inversión - coste de la inversión $)$ / coste de la inversión

"si el coste de la inversión se calcula en una moneda concreta, la ganancia de la inversión se debe calcular en la misma moneda" (p. 257). No es posible por ejemplo adaptar esa ecuación al número de fans ganados en facebook:

ROI = (ganancia de fans de facebook - coste de la inversión $)$ / coste de la inversión

El ROI es un término que no se centra en los impactos no financieros (nuevos fans en las redes sociales, solicitudes de información, nuevas de visitas a la página web, etc), simplemente es un resultado cuantificable que implica el retorno de toda la inversión hecha en todos los departamentos de la empresa.

La manera de relacionar el ROI con los social media gira entorno a las conversiones para Blanchard (2012):

La empresa convierte financiación en recursos. Estos recursos convierten su financiación en actividades en la red social. Estas actividades se convierten en interacciones entre la marca y los usuarios de redes sociales. Estas interacciones se convierten en ancho de banda. Este ancho de banda se convierte en resultados no financieros: seguidores, menciones, sentimiento, clics, descargas, recomendaciones, respuestas, participación en charlas, recursos compartidos, retweets, etc. Los cambios en estos resultados no financieros se pueden interpretar como la manifestación de variaciones en la familiaridad, la alineación, las preferencias y, por último, los hábitos de compra. En última instancia, los resultados no financieros se convierten en resultado financieros. (p. 260)

Con lo expuesto anteriormente por ejemplo si el objetivo de estar en los social media para una empresa es obtener solicitudes de cotización, en el caso de Provejec, se podría definir que todas las solicitudes de cotización que se concretó la venta y que llegaron por los canales de social media vendría a ser el retorno de la inversión.

No obstante; para Rodríguez y Gurús (2011) debido a lo complicado que es medir el retorno de la inversión que proviene de los social media plantean el concepto de ROR o retorno sobre las relaciones. Este concepto se basa en medir "el impacto de las 
relaciones con las personas a través de variables como la participación, la autoridad, la influencia y otras variables más fácilmente cuantificables como las planteadas en otro tipo de análisis web (tráfico, tiempo en la web, entradas, salidas, etc”. (p. 288)

En social media existen una gran cantidad de redes sociales de todos tipos las cuales cada una tiene sus propias características, se describirá las redes sociales que se utilizaron para la estrategia digital de este proyecto:

- Facebook: La red social más grande e importante en la actualidad. En el 2013 Facebook "tenía más de 1.200 millones de usuarios activos (se consideran activos aquellos que han entrado a la red social al menos una vez en el último mes) en todo el planeta..." (Moreno, 2014). Tanto empresas, personas, marcas, etc., pueden crearse un perfil en Facebook y compartir, fotos, videos, comentarios, contenido en general.

- Linkedin: Red social profesional con más de trescientos millones de usuarios activos al mes. Los usuarios de esta red social muestran su perfil profesional y las empresas también tiene un perfil profesional. Se utiliza para buscar empleo y compartir temas del entorno de la empleabilidad laboral.

- Youtube: Plataforma para subir de videos que le pertenece a Google. "Tiene elementos 2.0, tales como la posibilidad de seguir a otros usuarios, compartir contenido, comentar, etc.” (Moreno, 2014, p 149)

Ya que Provejec no tenía un estrategia digital definida el siguiente paso después de conocer la importancia de estar en los social media es planear la estrategia digital o el social media plan. Para esto García (2012) nos señala una metodología a seguir con los siguientes pasos que se aplicó para elaborar la estrategia de Provejec:

1. Investigación y análisis: conocer la empresa, la filosofía, crear la marca, entender su funcionamiento, conocer el nicho de mercado, a la audiencia, a los competidores, son algunos de los actores trascendentales para su conocimiento un análisis de 360 grados del "contexto y "entorno" que nos facilitaran el desarrollo y diseño de una estrategia adecuada y acorde. 
2. Establecimiento de objetivos: debemos establecer una meta, saber en todo momento dónde estamos y cuál es nuestro objetivo para poder dibujar la ruta adecuada a seguir. Los objetivos siempre han de establecerse a corto, medio y largo plazo y han de ser coherentes y tener continuidad.

3. Diseño de tácticas: ya antes definimos táctica frente a estrategia como acciones específicas en el tiempo, que están marcadas por un determinado hito (target) al cual se orientan y que nos ayudan a seguir una planificación determinada. Es, dicho de otro modo, cada uno de los pasos que vamos dando a lo largo de nuestra ruta.

4. Implementación y gestión: una vez tenemos descritas y definidas las acciones a llevar a cabo, las ponemos en marcha, las gestionamos a través de los diferentes medios y canales que se hayan establecido en las estrategias y tácticas. Un trabajo especialmente dirigido a Community y Social Media managers.

5. Monitorización: recordemos, o que no podemos medir o cuantificar, no podemos evaluarlo y por lo tanto, no podemos saber si funciona o no y por ende, mejorarlo. Establecer las KPIs y medir los resultados de las acciones, es sin duda una de las tareas que suscitan más interés y polémica, por su complejidad, junto a la generación de contenidos de interés.

6. Revisión: la monitorización da lugar a una serie de datos, número, cifras, que nos indican si estamos haciendo las cosas bien o mal. Sin embargo, las cifras sin un estudio, análisis, y evaluación adecuada, sin la interpretación correcta, no son más útiles que la intuición, que aunque necesaria, no es suficiente para una estrategia de éxito, El social media manager o strategist debe de ser capaz de interpretar las cifra y los datos que arrojan nuestras acciones con una perspectiva y visión global, tanto de nosotros, como de los clientes, usuarios y la competencia, así como las tendencias del mercado. (p. 55-56)

Cada sector industrial tiene un público objetivo diferente para Provejec que uno de sus productos principales son grupos electrógenos, su público objetivo es bien particular y no es masivo. Debido a esto, en la parte de investigación de la metodología, definir al público objetivo en Social Media es de suma importancia en cualquier campaña de marketing. La ventaja de las redes sociales a diferencia de los medios tradicionales es que te brindan herramientas de segmentación bien específicas. Si el público objetivo es una persona, diez, cien, mil o un millón de usuarios, actualmente existen los medios para dirigirse a ellos (Kerpen, 2012). Esta ventaja se aplicó para segmentar en redes sociales al público objetivo de Provejec.

Facebook tiene un sistema de segmentación para sus anuncios el cual te permite elegir tu público objetivo en base a múltiples características. Las opciones de segmentación de Facebook son: ubicación, datos demográficos, intereses, cumpleaños, relación, idiomas y empleo. En el caso de LinkedIn la segmentación de los anuncios se acopla más a 
establecer relaciones con empresas (B2B), ya que se centra más en filtrar a los usuarios por: sector empresarial, cargo que desempeña, tamaño de la empresa, la edad, el género y la ubicación geográfica. Una ventaja de LinkedIn que señala Kerpen (2012) es que "hay profesionales, sobre todo los altos directivos, que no están registrados en Facebook. Es muy posible que logre localizarlos en LinkedIn" (p. 47).

Por otro lado, para García (2012) al momento de definir los objetivos en social media siempre hay que tener en cuenta nuestro producto, el nicho de mercado al que nos dirigimos, las posibilidades y capacidades, si fuera de otro modo podríamos plantear objetivos irracionales. (p. 69)

Como se mencionó en varias ocasiones el contenido es el rey en marketing digital y es necesario también hacer un plan de contenidos, ya que aportar contenido relevante a los usuarios mejora el interés de estos por la marca. Si para nuestros fans y seguidores es relevante el contenido mostrado, el nivel de confianza que tendrán hacia nuestra empresa será mayor (Kerpen, 2012).

En el plan de contenido se debe definir las temáticas de las publicaciones en las distintas redes sociales atendiendo a las palabras clave de los productos o servicios de la empresa, luego es importante elegir el tono, estilo y enfoque de comunicación de las publicaciones (Moreno, 2014). Es fundamental que el contenido creado esté en relación a los intereses del público objetivo si esto no fuera así estaríamos perdiendo tiempo y recursos invertidos en temáticas irrelevantes para los usuarios y no estaríamos generando un impacto positivo.

Por consiguiente, crear un calendario donde estará definida la frecuencia de las publicaciones y el presupuesto a invertir es fundamental para tener un plan de acción bien organizado. Luego es necesario llevar el control y seguimiento de las publicaciones por medio de las métricas para sacar conclusiones (Moreno, 2014). Llevar un calendario y planificar los contenidos resulta de gran ayuda para no perder la frecuencia de publicación y controlar los presupuestos destinados para cada red social.

Por otro lado, el contenido mostrado tiene que tener ciertas características básicas para aportar valor a los usuarios: debe ser interesante; debe fomentar a la interacción; 
mensajes claros, sencillos directos y deben ser mensajes honestos. Es importante enriquecer los mensajes con imágenes, videos, infografías, etc.; que el contenido sea de actualidad; publicar casos de éxitos de la empresa y de otras empresas también (que no pertenezcan al rubro); mostrar el lado humano de la compañía; colocar enlaces que direccionen a tu página web (Moreno, 2014).

También, mostrar en el plan te contenidos el lado humano de la empresa es importante ya que sensibiliza al cliente, le da a entender que no sólo se preocupa por la satisfacción del cliente sino también por el bienestar de la sociedad. Es por esto que gran cantidad empresas incluyen en sus ejes temáticos consejos de cómo ayudar al medio ambiente o la responsabilidad social que practican.

Por otro lado, los videos son una herramienta muy valiosa en Social Media, "según la mayor parte de los expertos en contenidos en internet, el auge que en los últimos años está experimentando el video online es clave para saber que se compartirá más en el futuro" (Moreno, M. 2014, p. 85). Las empresas pueden sacar ventaja de esta tendencia con tener una estrategia de videomarketing dentro del plan de Social Media. En el caso de Provejec era de suma importancia tener material audiovisual ya que la gran mayoría de competidores medianos no contaba con este recurso.

Por lo tanto, es importante que los videos sean de calidad y que aporten valor al usuario; que el contenido esté relacionado con la actividad o imagen de la marca; que no sean muy largos de duración, entre 2 a 3 minutos como máximo, ya que es difícil retener al usuario (Moreno, 2014). Todas estas características que se mencionan se aplican a los videos de Provejec.

\subsection{Estrategia SEO y SEM.}

Para el caso de Provejec resulta importantísimo estar en los buscadores porque los potenciales clientes escriben en los motores de búsqueda los productos que están solicitando ya que estos no se encuentran fácilmente en cualquier centro comercial porque son productos del sector industrial y productos grandes. 
Antes de empezar plantear y definir los conceptos relacionados al SEO y SEM es necesario definir qué es un motor de búsqueda. Un motor de búsqueda es un sitio web que contiene una interfaz donde los usuarios pueden escribir varias palabras para buscar sitios webs relacionados con las palabras escritas. Los clasificación resultados que muestran los motores de búsqueda son en función a un algoritmo.

Por ende, los motores de búsqueda se han vuelto fundamentales para una buena estrategia digital, ya que las búsquedas por los usuarios o clientes actualmente son el modo principal para obtener información. A nivel mundial los usuarios utilizan los motores de búsqueda 131.000 millones de veces mensualmente. Eso equivale a 29 millones de búsqueda por minuto (Fox y Montero, 2013).

Las empresas y los sitios web están en constante competencia para aparecer en la primera página de los principales motores de búsqueda. Existen dos estrategias para lograr esto. La estrategia SEO o Search Engine Optimization (posicionamiento orgánico):

Consiste en optimizar nuestro site para lograr una buena posición en los términos de búsqueda más interesantes para nosotros, dentro de los llamados resultados naturales $\mathrm{u}$ orgánicos, es decir, aquellos que son fruto exclusivamente de la indexación basada en los algoritmos internos del buscador. No se puede pagar para conseguir una buena posición y el lograr un buen posicionamiento dependerá de otros factores. (Somalo, 2011 p. 71)

Y por otro lado está el posicionamiento de pago SEM o Search Engine Marketing:

Consiste en utilizar la posibilidad de colocar enlaces patrocinados para las palaras clave de nuestro interés, en los resultados de búsqueda de los usuarios. Se trata de una estrategia de pago y nuestros resultados dependen en gran medida, aunque no en exclusiva, de cuánto estemos dispuestos a pagar. (Somalo, 2011 p. 72)

Los anuncios en la estrategia SEM también se les suele llamar anuncio de pago por clic (PPC) porque sólo se paga cuando el usuario hace clic en el anuncio mostrado (Fox y Montero, 2013).

Por otro lado, los resultados orgánicos giran en torno a la indexación y la relevancia de la página web, los motores de búsqueda arrojan los resultados más completos y 
relevantes que consideren para garantizar una experiencia de usuario óptima (Fox y Montero, 2013).

El modo de funcionamiento de los motores de búsqueda se rige en sus arañas web que encuentran y luego analizan los sitios web reuniendo información (contenido de texto, metadatos y vínculos), luego los índices de los buscadores almacenan el contenido de las páginas webs. Luego se califican los sitios webs para determinar qué páginas son las más relevantes para cada búsqueda. Son varios factores para calificar cada página web y van cambiando en base a los nuevos algoritmos, los buscadores asocian cada unidad de contenido con un grupo de palabras clave (Fox y Montero, 2013).

Figura 7.5

Publicidad SEM y resultados SEO

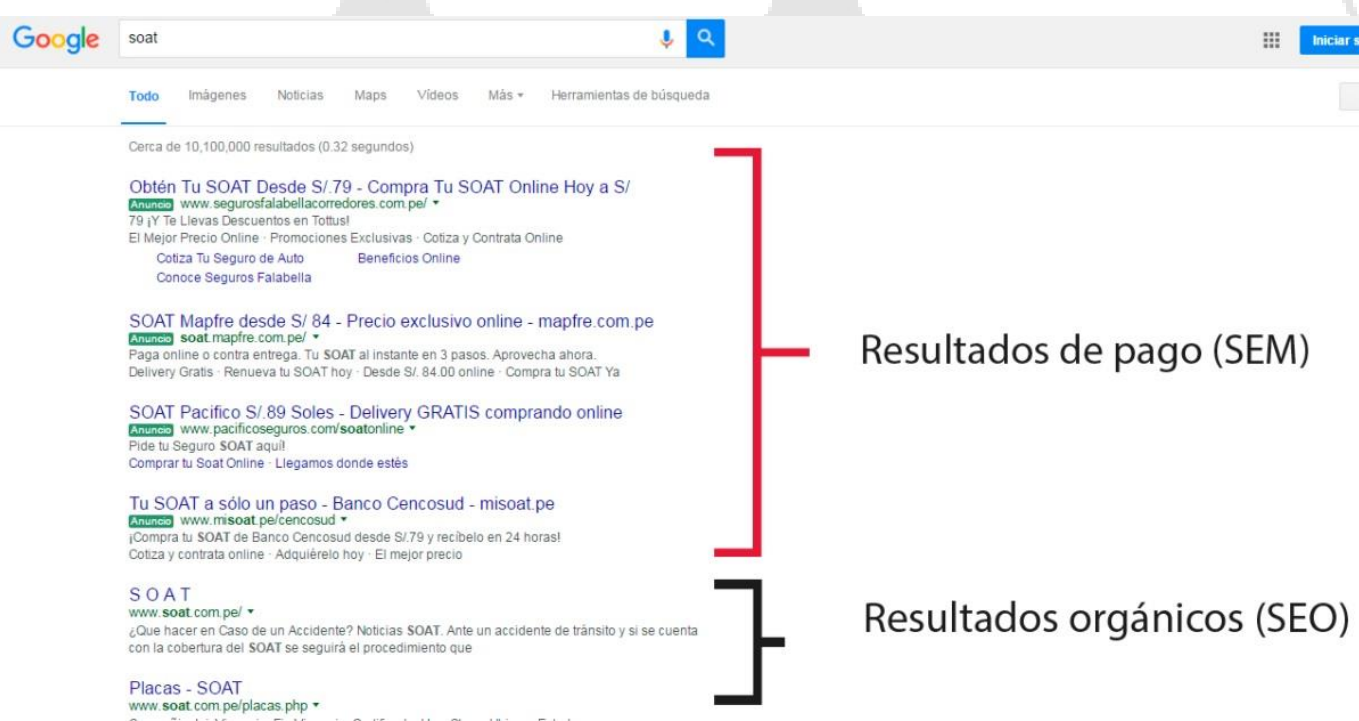

Fuente: captura de pantalla de Google.

Ya que Google tiene el control absoluto a nivel mundial de las búsquedas me centraré en las estrategias para este motor de búsqueda. Si bien es cierto se señaló algunas estrategias para mejorar el posicionamiento en los motores de búsqueda en los capítulos anteriores en esta parte se profundizará las estrategias que se ejecutaron para el sitio web de Provejec. 
Las estrategias o factores On-page es "todo aquello que hacemos en nuestra Web para mejorar, o empeorar aunque no queramos, la SERP (search engine result placements, clasificación en los resultados de los motores de búsqueda) de nuestro sitio web" (Fleischner, 2013 p. 33).

Una de las estrategias más importantes es la elección de la palabra clave o las palabras claves para nuestro sitio web. Según Fleischner (2013) la mejor forma de buscar las palabras claves más adecuadas son aquellas que todos los usuarios del entorno industrial usan de forma sistemática en Google para buscar los servicios o productos que ofrece la empresa (p. 35).

Por ende, resulta fundamental elegir bien las palabras clave porque "los algoritmos de los motores de búsqueda se basan sobre todo en palabras clave, es decir: palabras clave en nuestro sitio web, palabras clave en el código fuente, palabras clave en los ciclos internos y palabras clave en los vínculos dirigidos a nuestra web" (Fleischner, 2013, p. 52). Para el caso de Provejec resultó esencial esta estrategia ya que la empresa manejaba gran variedad de productos y servicios e implicaba gran cantidad de palabras clave.

Otra estrategia es la colocación de meta etiquetas (meta tag) a cada página web. Las meta etiquetas son como su nombre lo menciona, etiquetas que le asignas con las palabras claves seleccionadas a la página web y son primordiales para que los buscadores comprendan las páginas de nuestro sitio web, sepan qué información contienen, muestren una descripción en los resultados de búsqueda y sean capaces de indexación de cada página (Fleischner, 2013).

Asimismo, hay varios tipos de meta etiquetas y una de las principales es el título de la página (title). Esta etiqueta es fundamental, ya que aparte de informar el tema principal de la página al motor de búsqueda también se muestra como título en la página de resultados de búsqueda (Fleischner, 2013).

Otra metaetiqueta es description, es una descripción que aparece debajo del título de la página web. Es mejor utilizar dos veces la misma palabra clave en esta meta etiqueta, ya que influye directamente en los resultados de búsqueda y ayuda con la optimización y la tasa de clic. El mensaje de esta metaetiqueta tiene que ser único, conciso, atractivo y 
debe ofrecer contexto al contenido de la página porque el espacio es limitado. (Fox y Montero, 2013; Fleischner, 2013).

Según Fleischner (2013) la colocación de las palabras clave en las URL de cada página del sitio web "contribuye a mejorar muchos los resultados de búsqueda de Google. Contar con el perfil adecuado, incluida la URL, nombre de marca y palabras clave, también supone un empujón a nuestra clasificación en los motores de búsqueda” (p. 42).

Para el caso de las meta etiquetas y las URL se enfatizó a la agencia que se encargó de la programación del sitio web de Provejec colocarlas para poder escalar rápidamente posiciones en los resultados de búsqueda.

Por otro lado, otra estrategia de optimización SEO que está relacionada directamente con la experiencia del usuario y la navegabilidad es la vinculación interna del sitio web. Esta vinculación interna se refiere a la organización de los vínculos para llegar a otras páginas del mismo sitio web (Fleischner, 2013). Una característica de una buena navegabilidad es poder ir desde cualquier subpágina de un sitio web a la página de inicio o la anterior página visitada y esto lo premia Google.

La velocidad de descarga del sitio web es otro factor importante para Google. Los sitios webs que se descargan lo más rápido posible tienen mejores posiciones en las búsquedas ya que Google siempre quiere ofrecer la mejor experiencia al usuario (Fleischner, 2013). En el caso del sitio web de provejec se optimizaron las imágenes para obtener velocidad de descarga.

Como ya habíamos mencionado en los primeros capítulos el contenido es el rey en marketing digital. Producir contenido original es una excelente estrategia para la optimización en los motores de búsqueda. Los sitios web crean contenido dirigido al público objetivo para atraerlos. En el caso del sitio web de Provejec, se creó contenido audiovisual por medio de un canal de Youtube. Esto también se podría considerar estrategia on-page ya que los videos se pueden reproducir dentro del sitio web. A esto se le llama marketing de contenidos que su objetivo principal se basa en publicar contenido en nuestro sitio web y que se nos atribuya como autores únicos (Fleischner, 2013; Fox y Montero, 2013). 
Por otro lado, para realizar la descripción de todos los textos del sitio web es recomendable utilizar las palabras clave elegidas y que estén insertadas de forma natural, dando sentido a las frases, sin forzar su presencia y no redactando textos ilógicos de leer para el cliente. (Sico, 2011). Si Google se percata que están utilizando palabras clave sin darle sentido puede penalizar al sitio web.

También, hay factores o estrategias denominadas "off-page" que es todo aquello que podemos hacer en Internet, "menos en nuestra propia Web”, para mejorar los resultados en los motores de búsqueda" (Fleischner, 2013, p. 65). En el caso del Provejec se utilizó estas estrategias para complementar las estrategias dentro del sitio web y escalar rápidamente en el ranking de búsqueda con las principales palabras claves elegidas.

Los motores de búsqueda y especialmente Google premian a los sitios web por la calidad de contenido. El dilema está cuando el contenido es de calidad pero toda la información es sobre la empresa, no siendo de interés para otras webs enlazar. Para este caso se utiliza la principal estrategia “off-page” el "link-building” (Sico, 2011)..

Link-building es la "estrategia que trata de conseguir enlaces para mejorar el posicionamiento de sus páginas en los motores de búsqueda. Esta estrategia no consiste en engañar a los buscadores. Debe hacer que estos enlaces sean realizados de la forma más natural posible..." (Sico, A. 2011, p 136). Estos enlaces pueden provenir de otras páginas web o de las redes sociales. La calidad y la fiabilidad de los enlaces provenientes de otras web juegan un rol importante para Google. Los sitios que tengan enlaces de nuestra web tienen que ser sitios en los que confíen los buscadores y mientras más relevante sea el sitio que se encuentran los enlaces de una web será mejor para la calificación de los resultados de búsqueda. Ayuda notablemente también que los enlaces provengan de web del mismo rubro de negocio (Sico, 2011). En el caso de Provejec esta estrategia se aplicó y fue importante debido a que los sitios web de las marcas que Provejec representa en Perú colocaron en sus webs en enlace de Provejec indicando que son distribuidores autorizados.

Por otra parte, como vimos en el capítulo anterior las redes sociales se han vuelto un medio de interacción importante para las empresas y sus clientes. Según Fleischner 
(2013) hay dos respuestas de cómo se pueden utilizar las redes sociales para mejorar la clasificación de búsqueda en los motores de búsqueda: "vínculos" y "clasificaciones" (p.117). Que consisten en colocar los vínculos del sitio web en las publicaciones de redes sociales para aumentar las clasificaciones en los resultados de búsqueda. Sin embargo; existen otros factores como el contenido en las redes sociales que también influyen directamente en el SEO. "Google premia el contenido de valor (no sólo en webs, y blogs, también en redes y medios sociales, las conversaciones) no repetido, de hecho penaliza a aquellos que copian el contenido" (García, 2012, p. 58).

Según Fleischner (2013):

El verdadero valor de SEO de Facebook reside en la posibilidad de crear una red y perfiles a otros que publiquen o compartan sus vínculos en sus páginas de perfil, en su muro o en sus propios recursos digitales, como puede ser blogs y foros. Con el tiempo, su perfil y los vínculos distribuidos por quienes están en su red serán los que creen el valor de SEO. A medida que cada persona hace clic en ME GUSTA y que usted gana seguidores, consigue que crezca de forma exponencial el valor potencial de su cuenta en las redes sociales. (p 118)

Por otro lado, como se había mencionado tener un canal de Youtube empresarial en el sitio web resulta muy valioso para la estrategia SEO. Al colgar videos con temas relacionados a la empresa se está creando contenido relevante para los usuarios. La descripción de los videos tiene que contener palabras clave relacionadas al rubro y vínculos de la página web para reforzar la estrategia de "link-building" (Fleischner, 2013).

La publicidad SEM (Marketing para motores de búsqueda) como ya habíamos definido en la primera parte de este capítulo se basa en un método de pago por click o por impresión para que los anuncios salgan en las cuatro primeras posiciones o en la tres últimas del buscador (depende que tan dispuesto a pagar). En el caso de Provejec se optó por tener campañas de anuncios pagados en el motor de búsqueda Google para aumentar el tráfico del sitio web.

Las ventajas de hacer SEM son: conseguir muchas más visitas debido a que siempre los resultados de pago aparecen en las primeras posiciones de los resultados de búsqueda; comunicar mensaje más oportunistas ya que a diferencia del posicionamiento SEO los 
anuncios SEM son inmediatos; comunicar un mensaje más agresivo ya que tenemos la posibilidad de variar los textos de los anuncios (Somalo, 2011).

Para el diseño de una campaña de anuncios en los motores de búsqueda al igual que la estrategia SEO se tiene que elegir un conjunto de palabras claves que activarán los anuncios. Luego se procede a redactar anuncios respetando los estándares que Google asigna, es importante en los anuncios colocar cosas creativas y llamativas. Después se elegirá las páginas de destino (landing page) de los anuncios, estas pueden ser la página principal del sitio web o alguna subpágina de algún producto. Y por último se procede a colocar el costo por clic (CPC) y el presupuesto máximo que estás dispuesto a pagar el un sólo día. Google te permite optimizar y realizar cambios en cualquier momento de la campaña para mejorar la rentabilidad de lo invertido. En el caso de Provejec se ejecutó publicidad SEM y una agencia especializada se encargó la administración de las campañas.

\subsection{Benchmark. El ecosistema digital. Marketing Viral.}

\subsubsection{Benchmark}

Analizar a tu competencia en una estrategia de marketing tradicional es de suma importancia, lo mismo ocurre en una estrategia de Social Media. En las primeras etapas del plan de Social Media, incluso antes, es de suma importancia conocer a nuestra competencia en internet. Se tiene que analizar si la competencia directa tienen presencia en la red, qué tipo de estrategia utilizan y si han conseguido logros importantes (Redondo y Rojas, 2013). Sobre todo para las empresas que no son del sector retail el canal para mostrarse a los clientes es principalmente internet y es de suma importancia analizar a tu competencia para entender el contexto con el que vas a competir y poder planear exitosamente la estrategia digital.

Un benchmark en Social Media es:

Un estudio comparativo del desempeño en redes sociales de otras empresas similares a la nuestra en tamaño, geografía y estructura. Este proceso es fundamental para ponernos en situación antes de iniciar cualquier tipo de estrategia, para optimizar el potencial de la presencia de nuestra marca, productos o servicios en redes sociales y para tener una 
idea del alcance de las acciones que necesitamos ejecutar, una vez hayamos determinado contra qué y quién vamos a competir en la red. (Redondo y Rojas, 2013, pp. 47-48)

Siempre es fundamental hacer un benchmark, ya que al obtener información se puede analizar el comportamiento de la competencia en social media y si están siguiendo una buena trayectoria (Redondo y Rojas, 2013). En el caso de provejec se analizó los perfiles de la redes sociales y los sitios web de los 3 principales competidores.

\subsubsection{Ecosistema Digital}

Para poder realizar un análisis de la competencia es necesario conocer las plataformas en las que una empresa pueda tener presencia en internet. El ecosistema digital es el ambiente creado en internet por una empresa y está conformado por todas las plataformas en la red: redes sociales, sitio web, blogs, Email marketing, SEO, SEM, marketing de contenidos, analítica web, etc. El ecosistema digital sirve para a la empresas para posicionarse y mostrarse ante los miles de usuarios que navegan (¿Qué es y para qué Sirve el Ecosistema Digital para mi Pyme?, 2014)

\subsubsection{Marketing viral}

En las redes sociales de Provejec también se publicó contenido cotidiano y de actualidad y se relacionó con los productos de la empresa para lograr la viralización. El marketing viral es aquel que lo integran los cientos o miles de personas que deciden por voluntad propia compartir y/o recomendar a sus amigos y conocidos el contenido de nuestra campaña. De esta manera, el costo de difusón se reduce considerablemente. El reto es conseguir contenido interesante para lograr la difusión de lo usuarios (Somalo, 2011).

Sin embargo; no hay modo científico para tener éxito y viralizar algún contenido pero lo que sí es fundamental sorprender y ser creativo para que el usuario considere lo suficientemente interesante para compartirlo. Para que se viralice un contenido debe destacar, diferenciar del resto y tiene que lograr un nivel de masa crítica de difusión del cual todo el mundo empieza a hablar de él (Somalo, 2011). 
No siempre el contenido viral tiene que ser gracioso, "podemos conseguir viralidad con contenido mucho más serios y dirigidos a otro tipo de públicos más profesionales" (Somalo, 2011, p. 179).

\subsection{Analítica web, analítica social y KPI.}

En este capítulo se desarrollará los datos estadísticos y los KPI’S que muestran las plataformas de digitales de Provejec. La revisión y el análisis de estos es fundamental para validar si los objetivos planteados dieron resultados en la estrategia.

La analítica web es "todo el proceso de recopilación, medición y evaluación de los datos obtenidos en internet para entender y optimizar el uso de una página web. Dentro de ella se englobaría la <<analítica social〉>, que no es más que aplicar los principios de analítica web a las redes sociales (Moreno, 2014, p. 224). Para comprender bien la analítica web en nuestras campañas de marketing digital es importante registrar todas las métricas, darles sentido, analizarlos y obtener conclusiones para la optimización y la reducción de costos (Acera, 2012).

Es importante, antes de comprender las métricas, diferenciar un sitio web de una página web. Un sitio web es el conjunto de páginas webs que contienen un mismo dominio. Las métricas en analítica web es una medida cuantitativa que nos posibilita comprender el estado de un sitio web para un atributo o parámetro determinado (Acera, 2012). En el caso de Provejec, el sitio web contaba con varias páginas web con el mismo dominio principal.

Para Acera (2012) estas son las principales métricas que se analizan en un sitio web:

- Visitas o sesiones del sitio web: Las visitas indican el número de veces que los usuarios han estado en un sitio web en un periodo de tiempo.

- Usuarios o visitantes únicos: indican de forma aproximada el número de personas distintas que han accedido a un sitio web en un periodo de tiempo determinado.

- Promedio de tiempo de una página web

- Promedio de tiempo en el sitio web 
- Tasa de rebote: porcentaje de visitas a un sitio web que lo abandonan rápidamente y sin hacer un solo clic.

- Páginas vistas: indican el número de páginas mostradas en los navegadores.

- Páginas vistas únicas: métrica que reduce las repeticiones, pues si se accedió a una misma página repetidas veces durante la misma visita o sesión, sólo se contabilizará una vez.

- Páginas por visita: proporciona la media de páginas visualizadas por visita al sitio web (páginas/ visita):

- Tasa de salida: porcentaje de visitas que abandonan un sitio Web desde una página concreta, a la que se denomina página de salida.

- Tasa de conversión: porcentaje de objetivos conseguidos en relación al número de visitas. Una conversión es una visita que cumple un objetivo. (p. 45)

Con el análisis de estas métricas se puede analizar a profundidad el comportamiento de los usuarios de tu sitio web. Por ejemplo si la empresa tiene como objetivo que los usuarios entren más a la sección del producto principal con estas métricas se puede verificar que página del sitio web fue mas visitada.

En analítica web también están los indicadores de rendimiento o KPI que son las métricas que sirven para medir el progreso de los objetivos planteados. Dependiendo el tipo de negocio o empresa, el sitio web puede tener diferentes objetivos. Los objetivos del sitio web estarán en sintonía con los objetivos del negocio (Acera, 2012).

Por ejemplo para una empresa que vende maquinaria pesada:

\section{Tabla 7.1}

KPI’S de una empresa.

\begin{tabular}{|c|c|c|}
\hline Objetivo de negocio & Objetivo del negocio & KPI para objetivos de la web. \\
\hline $\begin{array}{l}\text { - } \quad \text { Vender maquinaria } \\
\text { pesada }\end{array}$ & $\begin{array}{ll}\text { - } & \text { Incrementar solicitudes } \\
\text { de información y } \\
\text { cotizaciones. } \\
\text { - Conseguir solicitudes de } \\
\text { información gracias a la } \\
\text { publicidad online. } \\
\text { Conseguir solicitudes de } \\
\text { información gracias al }\end{array}$ & $\begin{array}{l}\text { - Número de solicitudes } \\
\text { de información y } \\
\text { cotizaciones. } \\
\text { - Número de solicitudes } \\
\text { de información que } \\
\text { llegan a la publicidad } \\
\text { online. } \\
\text { - Conseguir solicitudes de }\end{array}$ \\
\hline
\end{tabular}




\begin{tabular}{|l|l|l|}
\hline & SEO. & $\begin{array}{l}\text { información gracias al } \\
\text { SEO. }\end{array}$ \\
\hline
\end{tabular}

Google Analytics también muestra una serie de informes que son útiles para analizar el desempeño del sitio web. Estos son los informes más importantes:

- Audiencia: Proporciona los datos sobre los visitantes

- Adquisición: Muestra las fuentes de llegada a la página web.

- Comportamiento: Proporciona datos sobre el contenido del sitio web y el comportamiento del usuario.

- Conversiones: Datos sobre los objetivos propuestos.

El informe de adquisición proporciona las siguientes fuentes de llegada:

- Búsqueda orgánica: muestra las sesiones procedentes de las búsquedas orgánicas del motor de búsqueda.

- Búsqueda de pago: muestra las sesiones procedentes de los anuncios de Google Adwords.

- Referencia: muestra las sesiones que proceden de otras páginas web.

- Directo: Muestra principalmente las sesiones que proceden de haber escrito URL en la barra de direcciones. También pueden ser sesiones provenientes de enlaces en documentos o correos electrónicos.

- Social: Muestras las sesiones que proceden de las redes sociales.

Con este informe se puede comprobar si las estrategias SEO, SEM y en redes sociales atrajeron tráfico al sitio web.

El informe de conversiones nos muestra los datos de los objetivos propuestos para el sitio web:

- Número total de conversiones.

- Porcentaje de conversiones. 
Luego de plantear los objetivos del sitio web, Google Analytics permite configurar y registrar los datos y luego analizarlos. Estos son los principales objetivos que se pueden crear:

- URL de destino: Cuando el objetivo consista en que el usuarios llegue o visita una determinada página del sitio web.

- Tiempo en el sitio: Cuando el objetivo sea que el usuario permanezca en el sitio Web un tiempo mayor o menor que el especificado.

- Página/visita: Cuando el objetivo sea que el usuario visite un número de páginas menor, igual o mayor al especificado.

- Evento: Cuando el objetivo consista en que se produzca un evento previamente configurado.

La analítica en las redes sociales "introducen también variables cuantitativas que, aunque son más complicadas de medir, no puede dejarse de lado, ya que incorporan información muy valiosa. Ahora se debe medir también la influencia, la relevancia, la fidelidad de los usuarios (Moreno, 2014, p.225).

Asimismo, Facebook “dispone de un panel de estadísticas (Facebook Insights) que nos proporciona datos sobre el rendimiento de la página, especialmente sobre las tendencias de uso y datos demográficos de los usuarios, así como del consumo y creación de contenido. Por ejemplo, nos informa del número total de fans, sus interacciones con la página y el número de publicaciones. Todos estos datos se pueden manipular para verlos en distintos gráficos y que obtener una visión rápida de lo que está ocurriendo" (Carballar y Sánchez, 2013, p. 223).

Las principales métricas de Facebook son:

- Alcance orgánico: Muestras cuantos usuarios únicos vieron una publicación orgánicamente.

- Alance pagado: Muestras cuantos usuarios únicos vieron una publicación por medio de la pauta. 
- Reacciones: Número de reacciones que tuvo la publicación. (Me gusta, me encanta, me entristece, me asombra, me divierte, me enoja).

- Compartido: veces que se compartió una publicación.

- Clics en enlace: clic en el enlace que contiene una publicación.

- Otros clics: clics en las fotos, en la fanpage, etc.

Del mismo modo, LindkedIn al ser una red social de porte profesional se invirtió también en esta red. LinkedIn también presenta métricas básicas del comportamiento de los usuarios con respecto a las publicaciones de la página empresarial. Entre las métricas más importantes tenemos:

- Seguidores

- Impresiones: Número de veces que el anuncio se mostró.

- Clic: El número de clics en el anuncio. Incluye clics en el contenido del anuncio y en el nombre y logotipo de tu empresa pero excluye algunas acciones sociales como las recomendaciones, los comentarios y los elementos compartidos.

- Acciones sociales: Número de interacciones de la publicación.

- Recomendaciones: veces que se compartió la publicación

- CTR medio: porcentaje con que frecuencia los usuarios visitas el sitio web porque vieron el anuncio.

El primer paso para empezar la estrategia digital de la empresa fue asegurar que el nuevo sitio web de Provejec cumpla con los estándares de usabilidad, accesibilidad, experiencia del usuario y buenas prácticas SEO. Luego se procedió a tener presencia en redes sociales con la elaboración de los ejes temáticos para Facebook y LinkedIn y paralelamente teniendo buenas prácticas SEO offpage y onpage. Por último por medio de la analítica web se logró medir los resultados de la estrategia. 


\section{CAPÍTULO VIII: LECCIONES APRENDIDAS}

A principios del 2015 el ecosistema digital de Provejec se basaba principalmente en un muy básico sitio web. La contratación del autor de este proyecto en Provejec fue para lograr el objetivo de mejorar la presencia de la empresa en internet y aprovechar las oportunidades de la digitalización al máximo.

Antes de plantear toda la estrategia digital primero era necesario conocer los productos, el modo de operación de la empresa y todo lo relacionado al rubro para luego poder definir al público objetivo. Es por esto que se observó la forma de trabajo en los servicios que brindaba Provejec y se elaboró entrevistas a los colaboradores. Luego se realizó un análisis de la presencia de la competencia en internet para tener un panorama más claro del ecosistema digital en general y ver que estrategias no estaban utilizando los competidores para implementarlas en la estrategia digital de Provejec. Con la información obtenida y posteriormente el análisis se procedió a gestionar la elaboración de un nuevo sitio web que cumpla con los últimos estándares de usabilidad, experiencia de usuario y accesibilidad. El objetivo del nuevo sitio fue obtener solicitudes de cotización.

Después se planteó y ejecutó la estrategia en redes sociales. Esta estrategia se basó en crear contenido relevante para el público objetivo para lograr tráfico para el sitio web. Posteriormente de aplicó buenas prácticas SEO. La principal estrategia SEO aplicada fue la creación de contenido audiovisual por medio de un canal de Youtube y la estrategia de link-building. También se implementó campañas de publicidad SEM por medio de GoogleAdwords.

Por último se midió los resultados de toda la estrategia por medio de la analítica web y los KPI’S que fueron principalmente el número de solicitudes de cotización y la visitas al sitio web.

El aprendizaje obtenido después de la elaboración de este proyecto es poder crear una estrategia digital de una empresa a partir de un análisis previo y un conocimiento profundo del rubro. 
Otro aprendizaje obtenido es poder analizar las métricas en social media para optimizar la inversión en base a los objetivos planteados. Uno de los objetivos principales de toda la estrategia es obtener solicitudes de cotización, debido al análisis de las métricas se procedió a invertir en contenido que logrará más conversiones.

Estas son otras lecciones aprendidas:

- Los clientes que buscan productos del sector industrial como los grupos electrógenos están aumentando su participación en redes sociales. Están abiertos a recibir cotizaciones formales de estos productos por este medio.

- Los motores de búsqueda van a seguir siendo el principal canal de búsqueda para los productos industriales. Para una mediana empresa que quiere obtener conversiones rápidamente es necesario optar por la estrategia SEO y SEM.

- El contenido relevante para los clientes y mostrar el modo de trabajo de la empresa en el sitio web de una mediana empresa es fundamental para generar confianza en los clientes.

- Promocionar los productos por redes sociales con pauta puede ser tan efectivo en convenciones como una campaña de publicidad SEM.

- Implementar un chat interactivo en el sitio web de la empresa puede mejorar lo índices de conversión y mejorar la relación con los clientes.

Recomendaciones:

- En un mediano plazo utilizar la base de datos obtenidas por medio del sitio web para realizar campañas de E-mailing.

- Seguir con la estrategia de contenido audiovisual en Youtube. Colocar pauta a los videos para lograr un mayor alcance. 
- Aumentar el presupuesto en pauta digital. Invertir en otro tipo de publicidad en internet. Programatic sería una opción muy rentable.

- Aumentar el presupuesto en LinkedIn. Esta red social profesional está ligada más al público objetivo de Provejec.

- Invertir en la publicidad display de Google.

- Sumar las ventas de las cotizaciones que llegaron por medio del canal digital para relacionar esas ventas al ROI de la empresa. 


\section{REFERENCIAS}

Acera, M. A. (2012). Analítica Web. Madrid: Anaya Multimedia.

Blanchard, O. (2012). El retorno de la inversión en Social Media. Madrid: Anaya Multimedia

Carballar, F. J. A., \& Sánchez, F. P. (2013). Social media: Marketing personal y profesional. México, D.F: Alfaomega.

Chaffey, D., \& Ellis-Chadwick, F. (2014). Marketing digital: Estrategia, implementación y práctica. México, D.F: Pearson.

Fleischner, Michael H. (2013). SEO Práctico. Anaya Multimedia-Anaya Interactiva.

Fox, V., \& Montero, A. M. (2013). Marketing de la era Google. Madrid: Ediciones Anaya Multimedia.

García, D. V. (2012). Social media manager. Anaya Multimedia-Anaya In.

Hassan Montero, Y.; Martín Fernández, F.J.; Iazza, G. (5 de junio del 2013). Diseño Web Centrado en el Usuario: Usabilidad y Arquitectura de la Información. https://www.upf.edu/hipertextnet/numero-2/diseno_web.html

Herrera, F. ( 25 de abril del 2014). ¿Qué es y para qué Sirve el Ecosistema Digital para mi Pyme?. http://marketingenredesociales.com/que-es-y-para-que-sirve-el-ecosistemadigital-para-mi-pyme.html/

Maciá, D. F., \& Gosende, G. J. (2010). Marketing online: Estrategias para ganar clientes en Internet. Madrid: Anaya Multimedia.

Moreno, M. (2014). El gran libro del community manager: Técnicas y herramientas para sacarle partido a las redes sociales y triunfar en social media. Barcelona: Gestión 2000. 
Rodríguez, F. O., \& Gurús Press,. (2012). Curso de community manager. Madrid: Anaya multimedia.

Rosales, P. (2010). Estrategia digital: Cómo usar las nuevas tecnologías mejor que la competencia. España: Deusto

Redondo, M., \& Rojas, P. (2013). Cómo preparar un plan de social media marketing: En un mundo que ya es 2. O. Barcelona: Gestión 2000.

Rodríguez, F. O., \& Gurús Press. (2011). Community manager. Madrid: Anaya Multimedia.

Scott, David Meerman. (2010). Las nuevas reglas del marketing. Anaya MultimediaAnaya Interactiva

Somalo, Ignacio. (2011). Todo lo que hay que saber de Marketing online y comunicación digital. Madrid: Wolters Kluwer.

Sico, A. . (2011). Quiero que mi empresa salga en Google: Secretismo y realidad del posicionamiento en buscadores. Bogotá: Ediciones de la U

Kerpen, D. (2012). Me gusta: Conseguir el éxito en las redes sociales. Madrid: Anaya Multimedia 


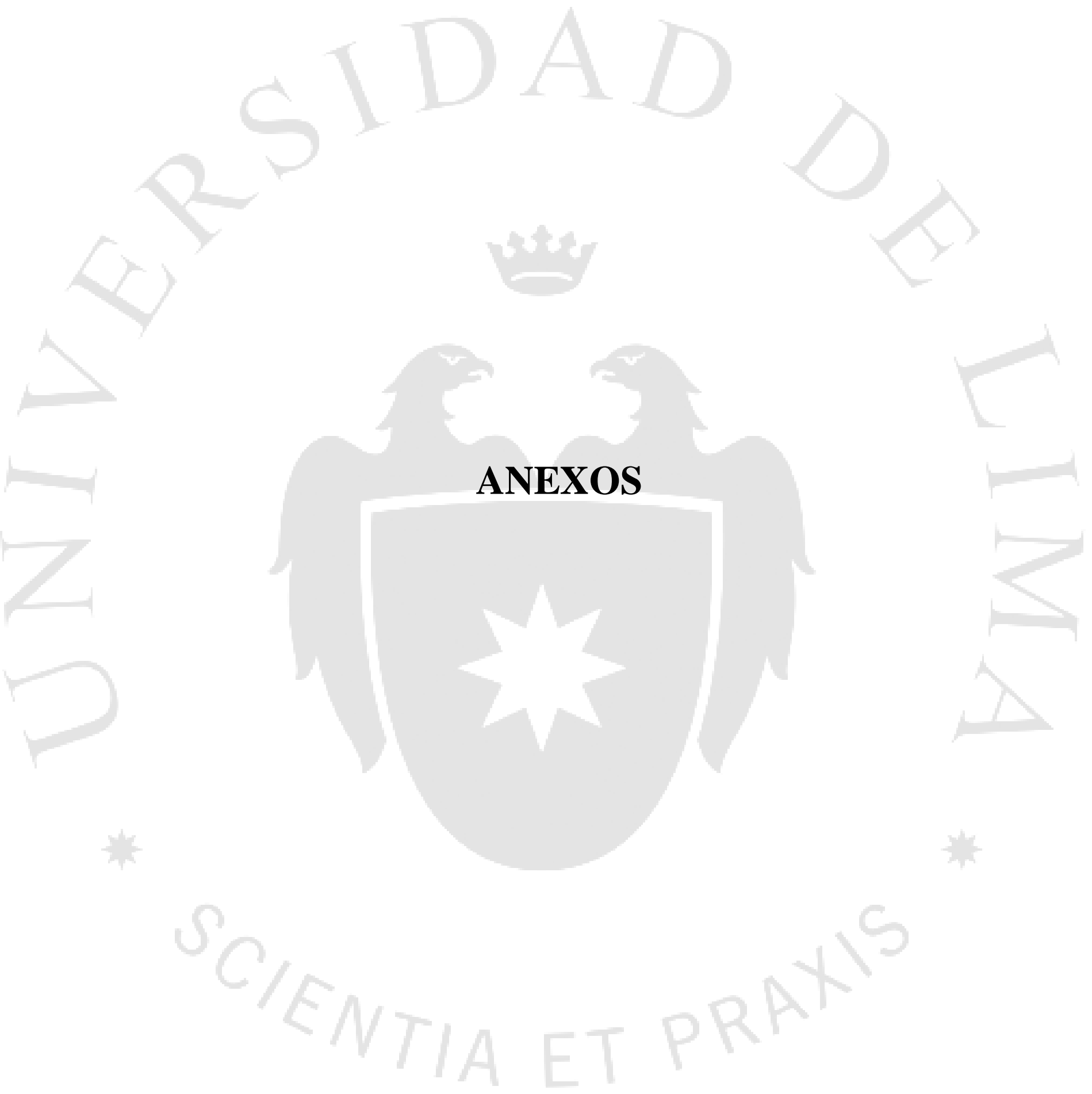




\section{ANEXO 1: Resultado orgánico de la palabra clave "grupo electrógeno Perú"}

Figura 9.1

Palabra: Grupos electrógeno Perú

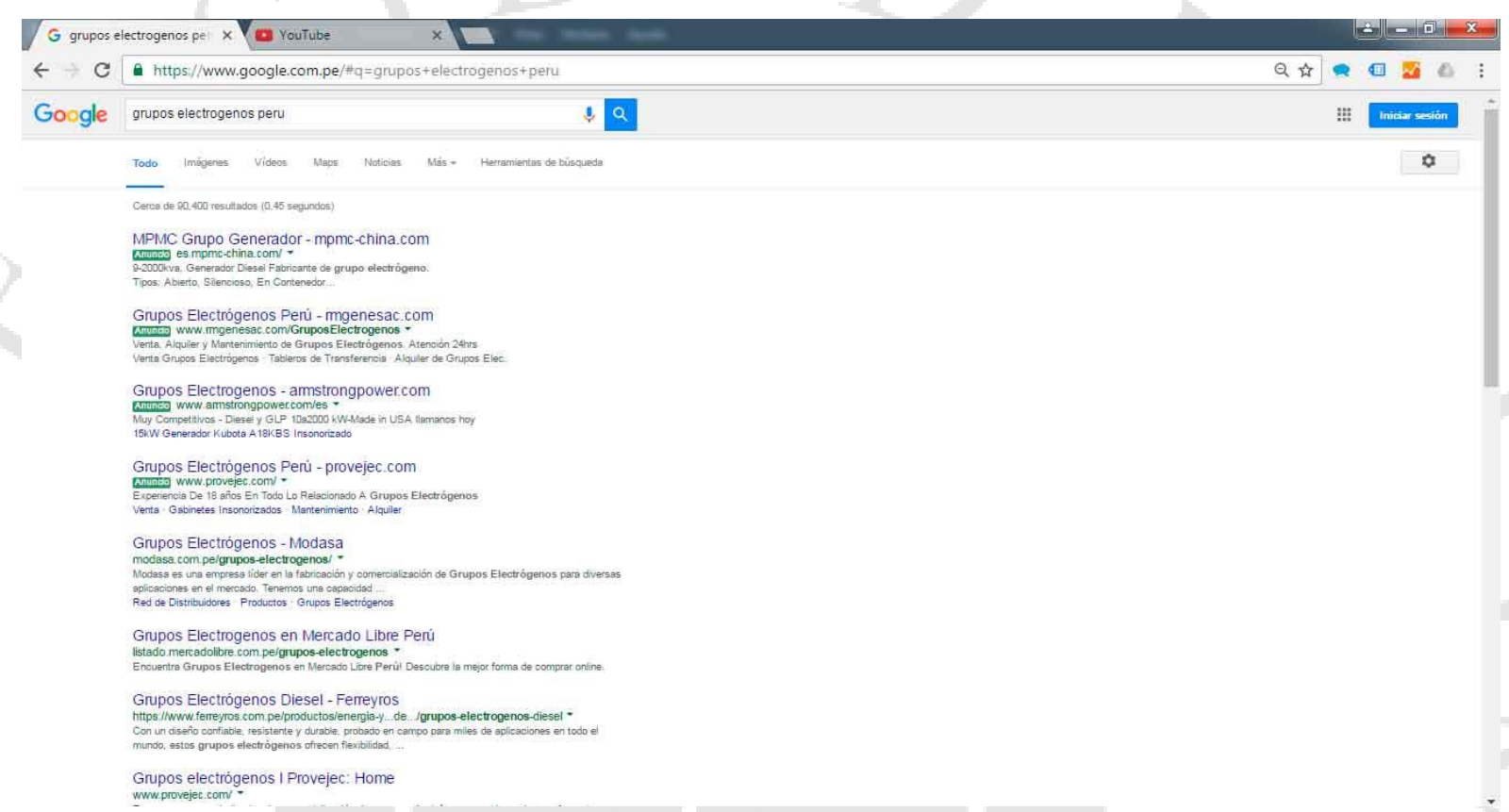




\section{ANEXO 2: Resultado orgánico de la palabra clave "grupo electrógeno biogás"}

Figura 9.2

Palabra: Grupos electrógeno biogás.

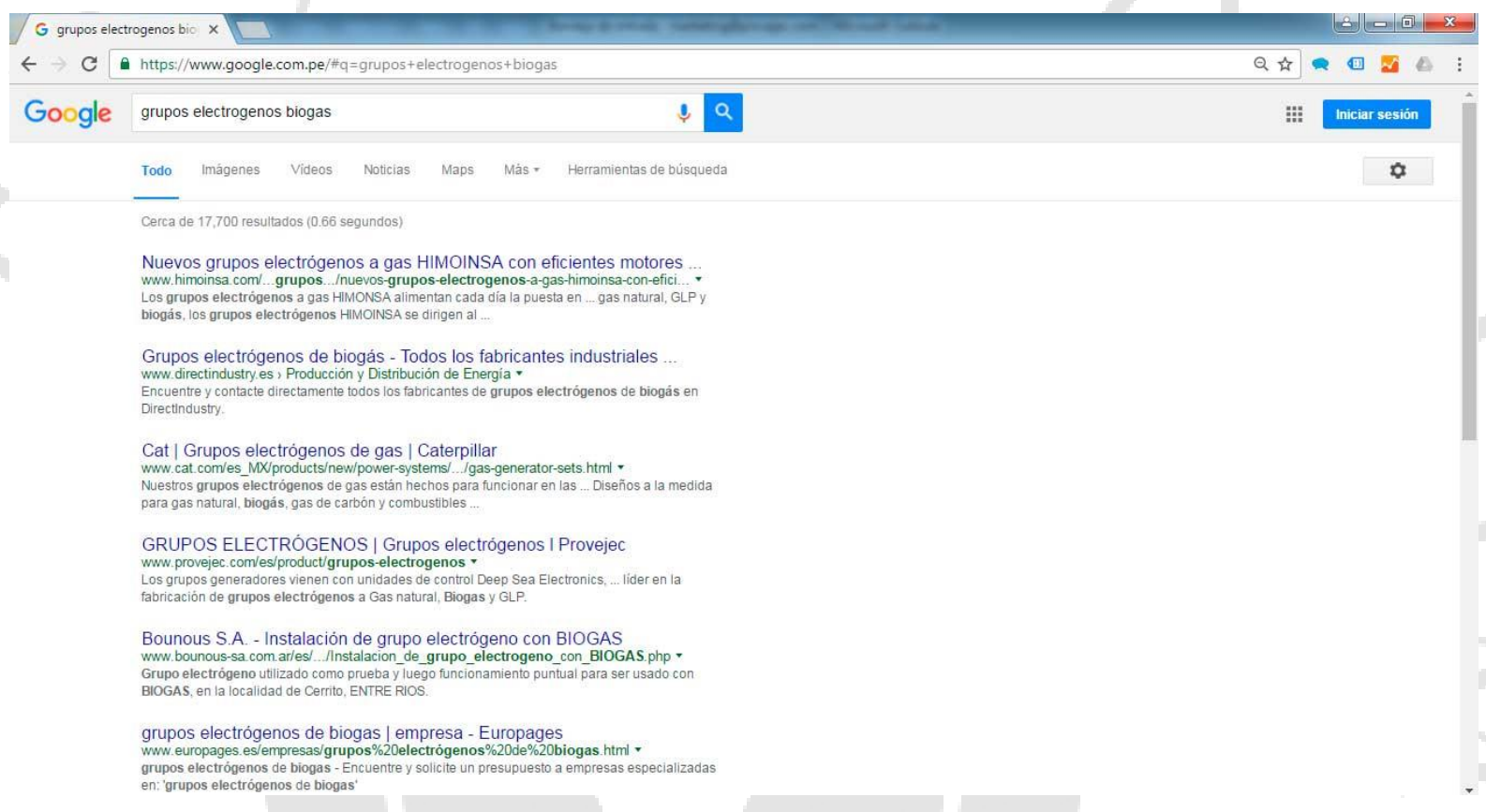




\section{ANEXO 3: Resultado orgánico de la palabra clave "tableros de transferencia"}

Figura 9.2

Palabra: Tableros de transferencia

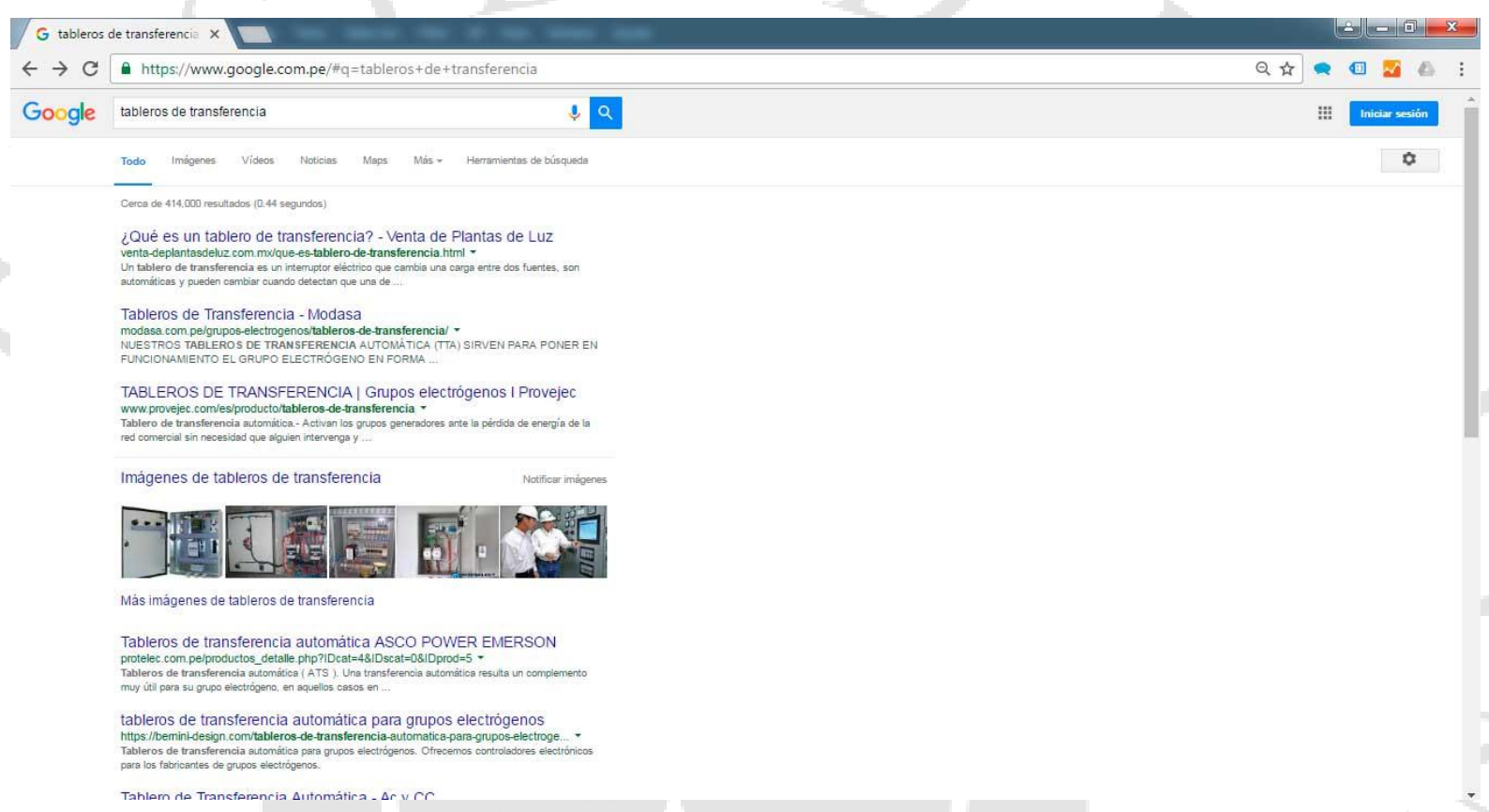




\section{ANEXO 4: Resultado orgánico de la palabra clave "Carretas"}

Figura 9.3

Palabra: Carretas.

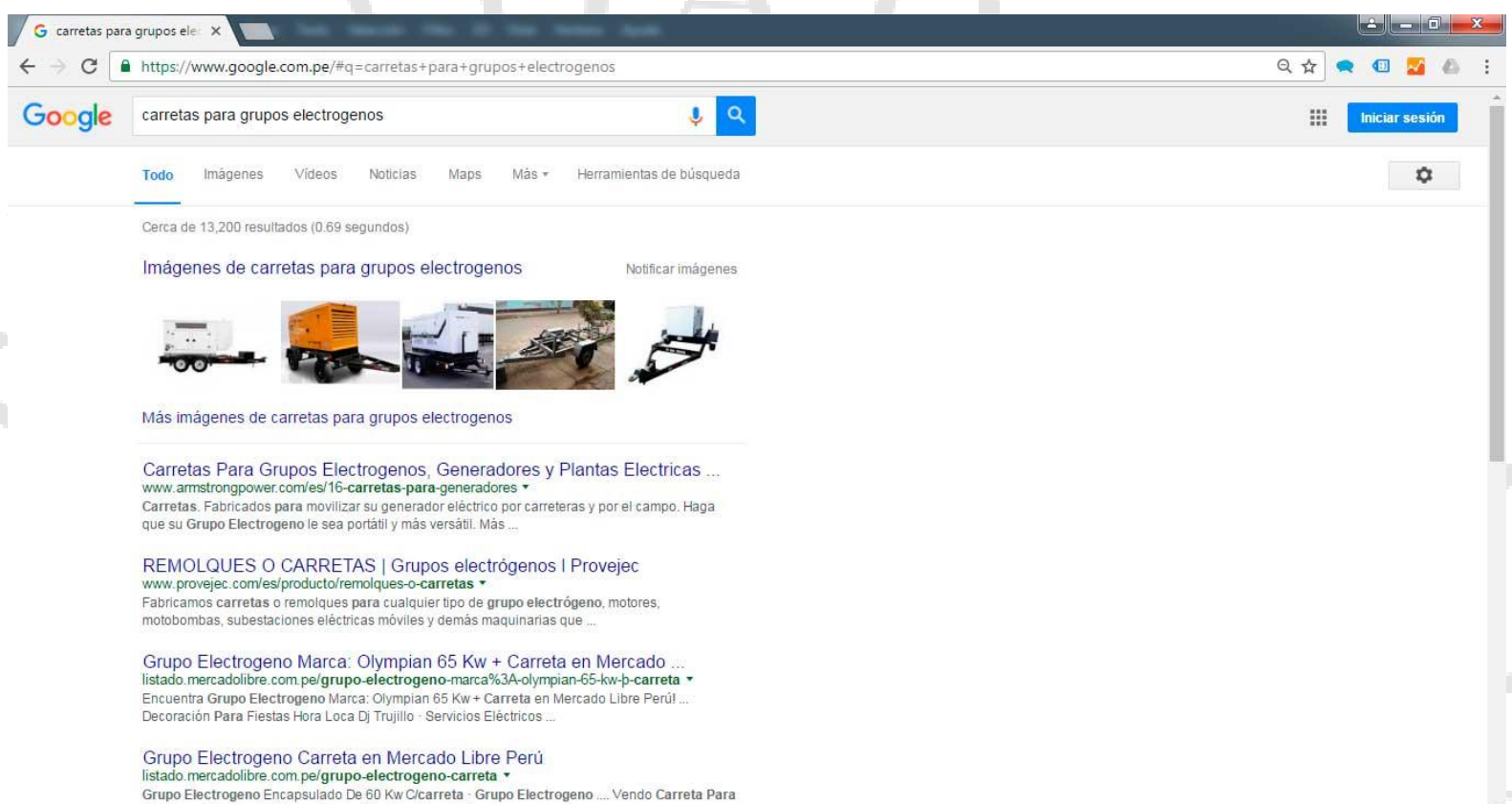




\section{ANEXO 4: Resultado orgánico de la palabra clave "Deep sea electronic peru"}

Figura 9.4

Palabra: Deep sea electronic peru.

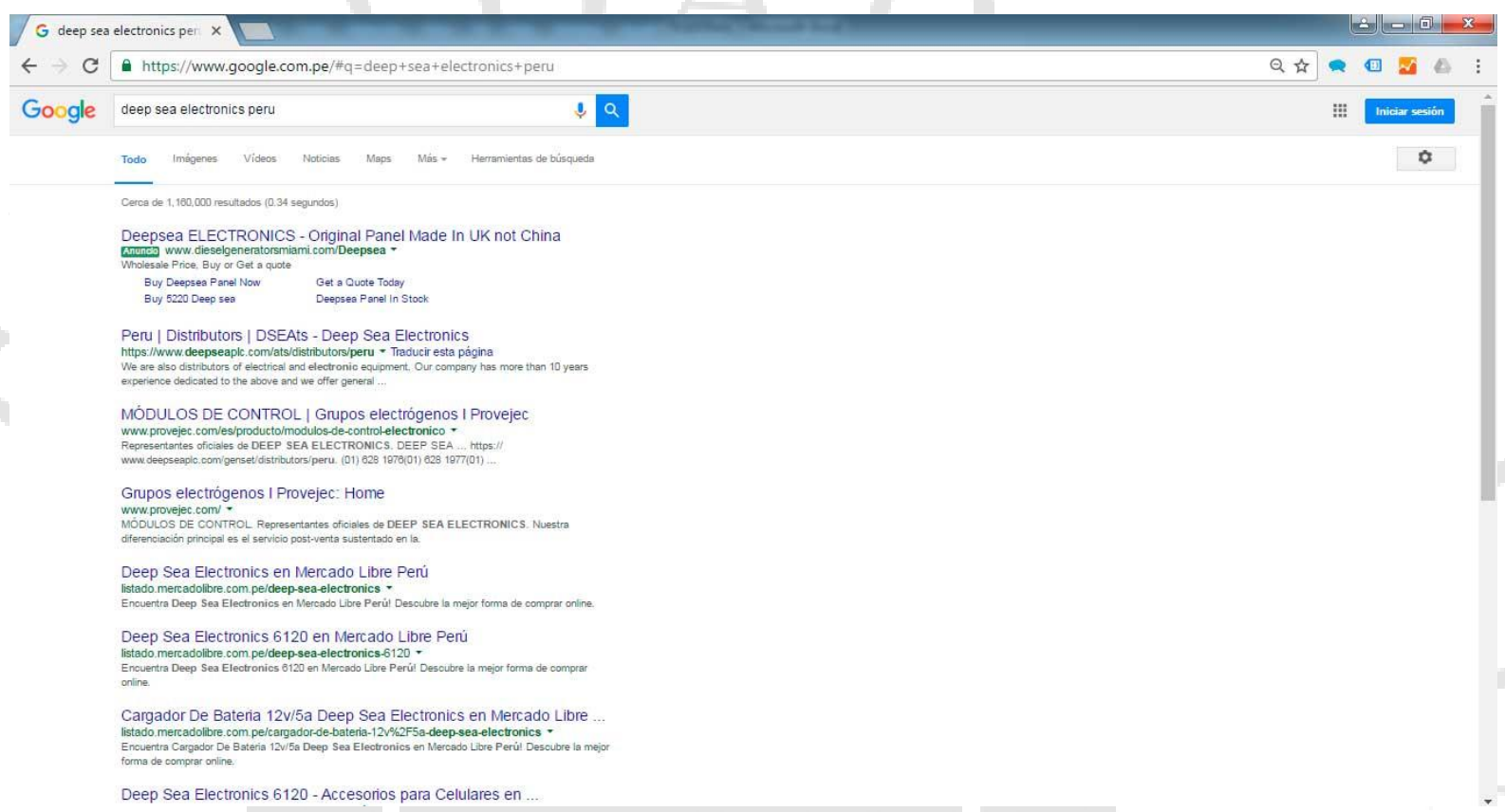




\section{ANEXO 5: Resultado orgánico de la palabra clave "encapsulado insonorizado"}

Figura 9.5

Palabra: Encapsulado Insonorizado

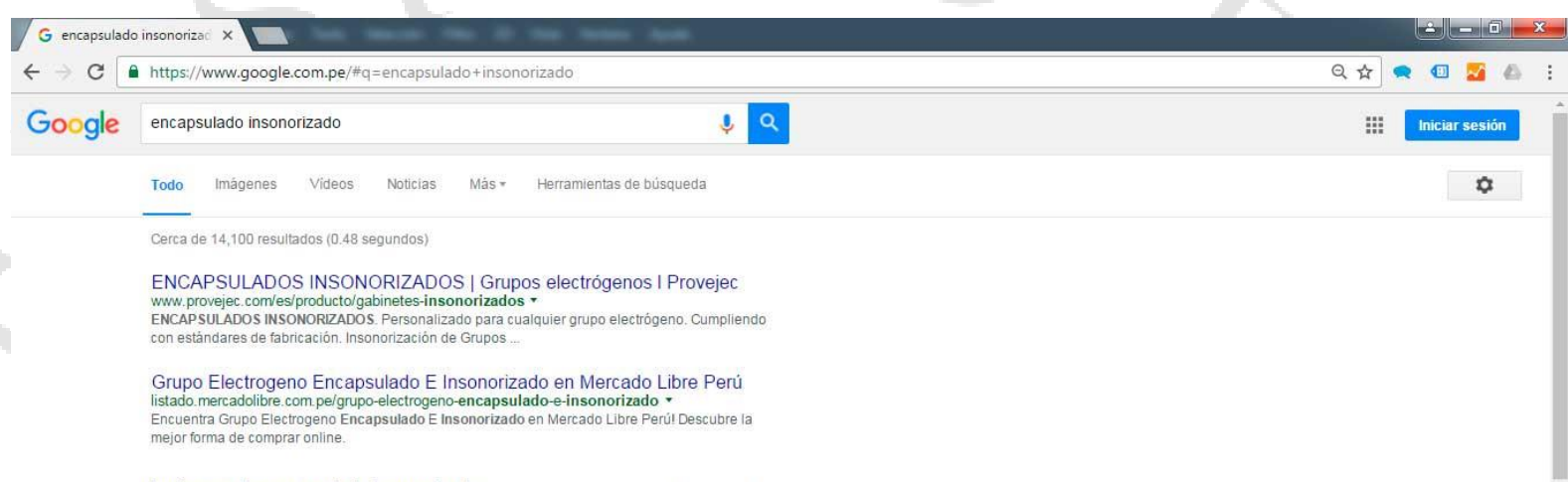

Imágenes de encapsulado insonorizado

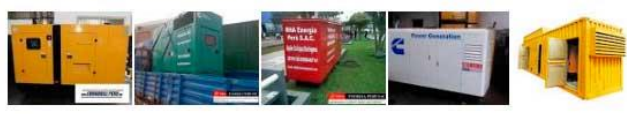

Más imágenes de encapsulado insonorizado

Grupo Electrogeno De $100 \mathrm{Kw}$ Nuevo Encapsulado Insonorizado en ...

listado.

Buen Precio Dos Grupos Electrogenos Encapsulado $360 k$.

Grupo Electrogeno Encapsulado E Insonorizado Vehiculos en

listado.mercadolibre.com pelgrupo-electrogeno-encapsulado-e-insonorizado-vehiculos - 


\section{ANEXO 6: Resultado orgánico de la palabra clave "módulo de control"}

Figura 9.6

Palabra: Módulo de control

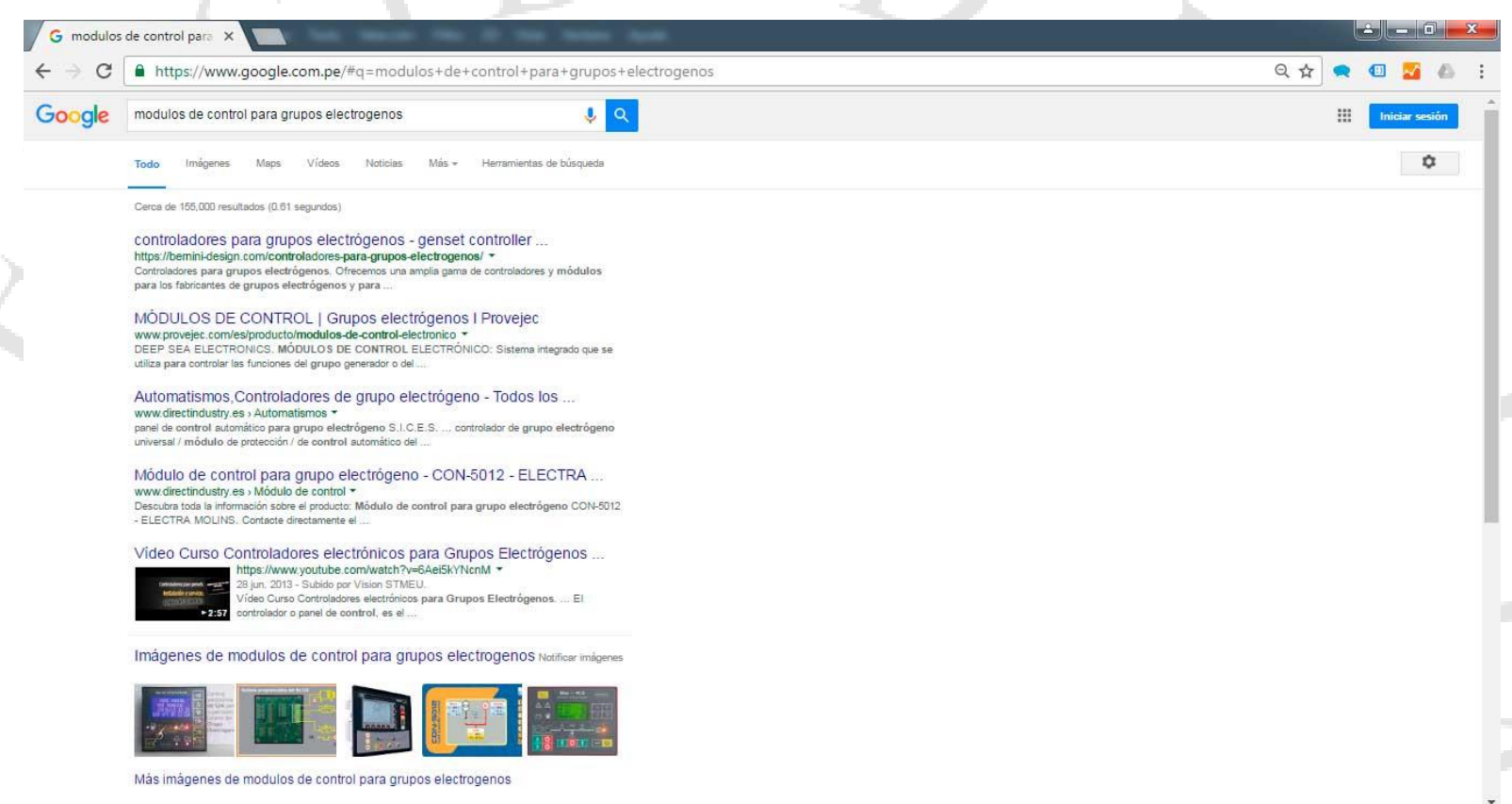




\section{ANEXO 7: Resultado orgánico de la palabra clave "Tanques de combustible"}

Figura 9.7

Palabra: Tanques de combustible.

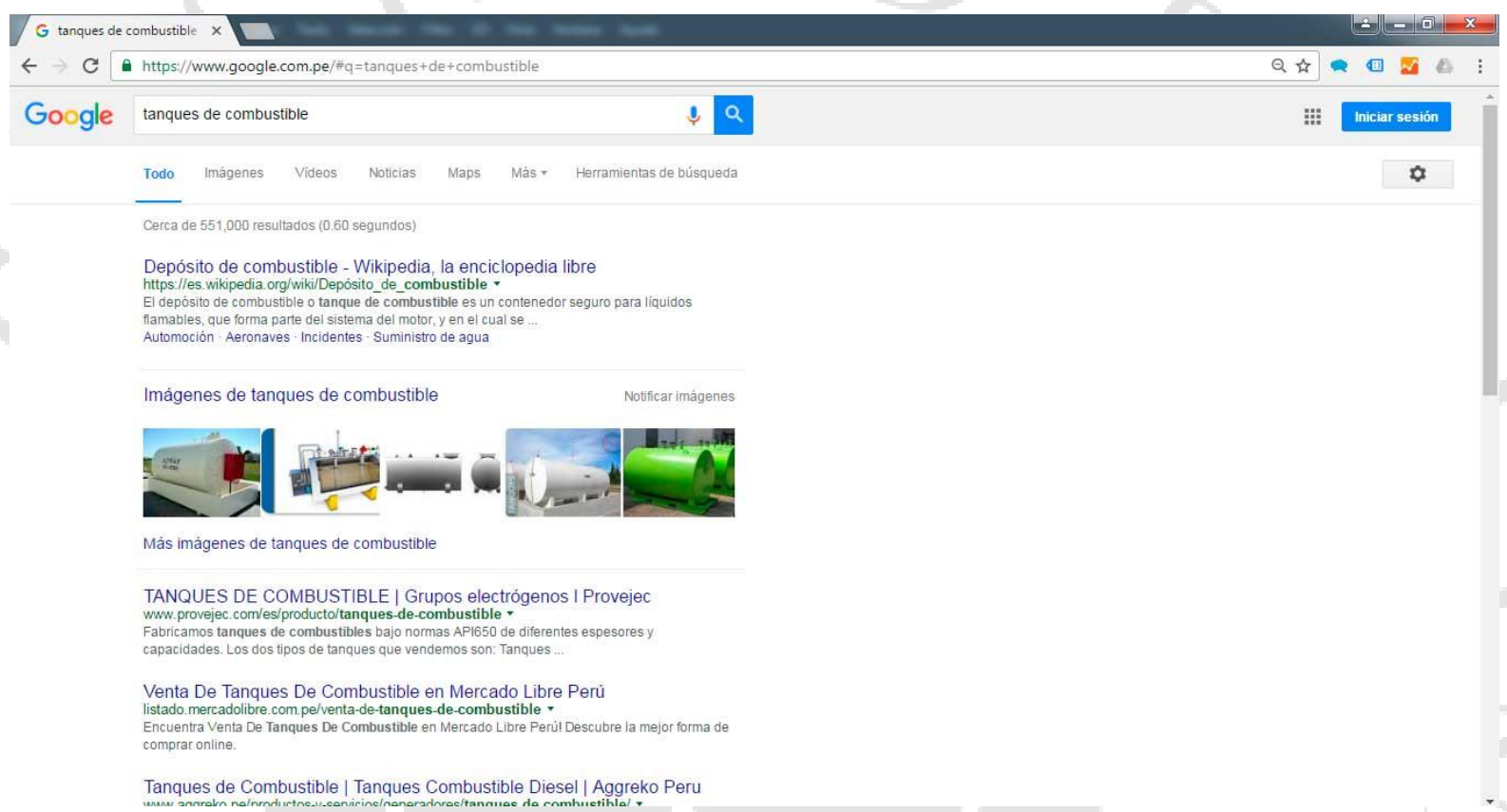

